\author{
Universidade de São Paulo \\ Museu de Arqueologia e Etnologia \\ Programa de Pós- Graduação em Arqueologia
}

\title{
Estudo comparativo dos sambaquis Caipora, Lageado e Jaboticabeira I: interpretações acerca da mudança de material construtivo ao longo do tempo
}

Tânia Ferraz de Oliveira

São Paulo

2010 


\author{
Universidade de São Paulo \\ Museu de Arqueologia e Etnologia \\ Programa de Pós- Graduação em Arqueologia
}

Estudo comparativo dos sambaquis Caipora, Lageado e Jaboticabeira I: interpretações acerca da mudança de material construtivo ao longo do tempo

Tânia Ferraz de Oliveira

Dissertação apresentada ao Programa de Pós-Graduação em Arqueologia do Museu de Arqueologia e Etnologia da Universidade de São Paulo para obtenção do título de Mestre em Arqueologia.

Orientador: Prof. Dr. Levy Figuti

Linha de Pesquisa: Processos de formação do Registro Arqueológico

São Paulo

2010 
Para a minha família 


\section{Agradecimentos}

Esta dissertação é fruto de um trabalho realizado por mim e por todos meus familiares, colegas e amigos que, por todos os momentos estiveram dispostos a me ajudar.

Agradeço primeiramente a minha mãe, Priscila, que sempre apoiou as decisões tomadas por mim em relação a vontade de me tornar arqueóloga. Obrigada mãe, por acreditar na importância da ciência e do conhecimento e por passar pra mim esses valores. Agradeço a meu pai Décio e irmãs Nati e Dé, que, juntamente com minha mãe, estiveram ao meu lado me dando suporte e demonstrando, acima de tudo, paciência. Vó, Tata, Esmeraldo, Marina, Cassius, Solange e Rafinha, obrigada pelo apoio!!

Agradeço ao meu orientador, Levy Figuti pela oportunidade e confiança que ele depositou em mim desde a iniciação científica, me mostrando o que é arqueologia do campo ao laboratório.

Não sei nem como agradecer ao meu querido Danilo, por milhares de motivos, entre eles por me mostrar que eu nunca estive sozinha, por me apresentar ao MAE, por participar de todo esse período estressante que é o desenvolvimento de um mestrado sem reclamar, além é claro, da companhia maravilhosa, de todo o carinho, amor e atenção que você sempre me deu!!!

Ao professor Paulo de Blasis, pela confiança e pelas dicas em campo e em laboratório, e por me dar a oportunidade de participar de um grande projeto de pesquisa como o Sambaquis e Paisagem.

Agradeço ao Cnpq pela bolsa, que foi de fundamental importância para que o trabalho pudesse ser concluído. Agradeço também ao MAE e a todos da biblioteca!

Pela ajuda em campo, agradeço a Fabi, Danilo, Rafael Milheira, Raquel Vaz, Edenir Perin, e Ximena. Rafael Brandi, querido Itajaí, obrigada pelos perfis e mapas, protetor solar e repelentes que só você possuía em todos os campos, além das risadas e cervejas no final do dia.

Aos meus queridos amigos do museu Fabiana Belém, Patrícia Fischer, Tati, André Penin, Chico Stuchi, Chico Pugliese, Arkley, Cíntia Bendazolli, Alexandre Hering, Terezinha, Ju, Mau, Gilmar, Raoni, Fernandão, Flavio Callipo, e Fabio, muuito obrigada pelas conversas e baladas. Não tenho palavras pra definir o quão importante 
foi o apoio de todos vocês, em todos os momentos dessa jornada. Attorre, mil vezes obrigada por me ajudar na confecção dos gráficos e tabelas!!

Eduardo Bespalez vulgo Chumbinho, obrigado pelos churrascos, por ter trazido o Feião pra nossa vida, pelas oportunidades de trabalho e aprendizagem em arqueologia que você me deu.

Aos funcionários do museu, seu Marinho, Ferreira, seu Odair, Regivaldo, obrigada pelos sambas!!

Agradeço também a Camila Bia e Gabi, por me auxiliarem na triagem dos componentes das camadas em laboratório. Sem a ajuda de vocês não sei se teria dado tempo!! Xexéu, obrigado pelos frangos recheados!

Agradeço a professora Deisi Farias, por abrir as portas do GRUPEP e a seus alunos por ajudarem nas pesquisas e coletas.

Deixo um obrigada também aos meus amigos da graduação em História, Família Abdala em geral, Donatelo, Eduardo, Rani, Chuck, por terem me apoiado e me distraído em momentos de puro desespero!!

Val, não tenho palavras!! Talvez, obrigado por existir!!

Enfim, agradeço a todos que, de alguma forma me ajudaram a manter a sanidade durante a confecção desta dissertação! 


\section{Índice}

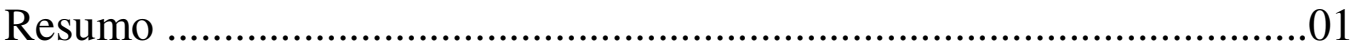

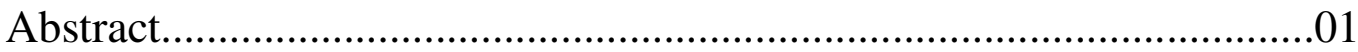

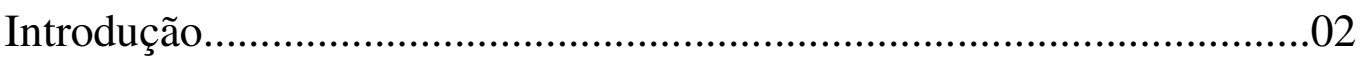

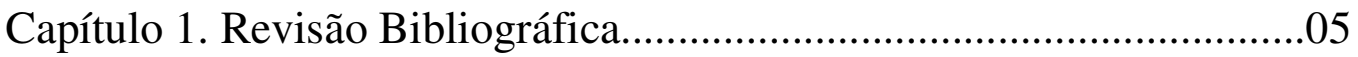

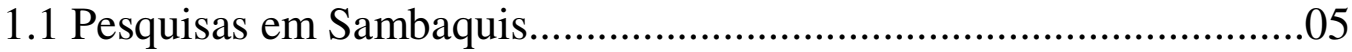

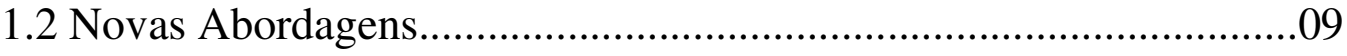

Capítulo 2. O Projeto e a Problemática de Pesquisa....................................12

2.1 Projeto Sambaquis e Paisagem..........................................................12

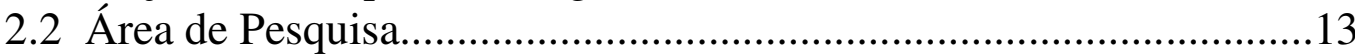

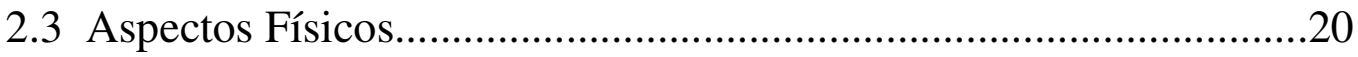

2.3.1 Clima e Vegetação.........................................................................22

2.3.2 Variação do Nível do Mar............................................................23

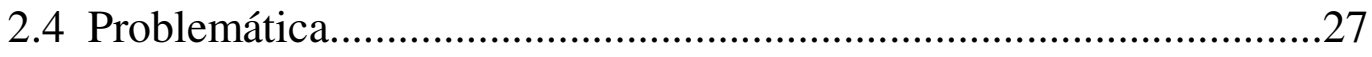

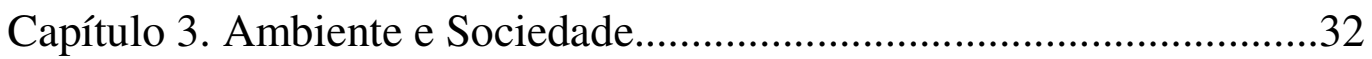

3.1 Distribuição dos sítios e cronologia....................................................41

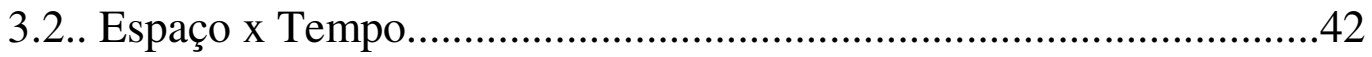

Capítulo 4. Material e Métodos....................................47

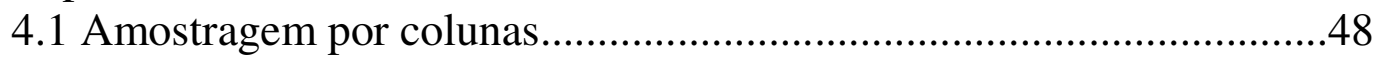

4.2 Metodologia de análise em laboratório...............................................49

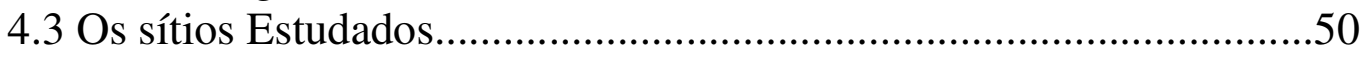

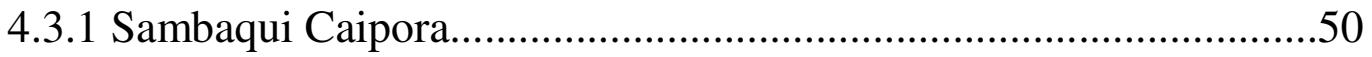

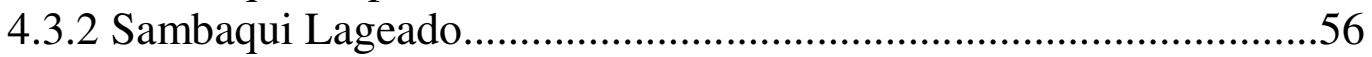

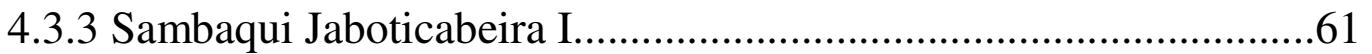

Capítulo 5 - Apresentação dos Resultados..................................................71

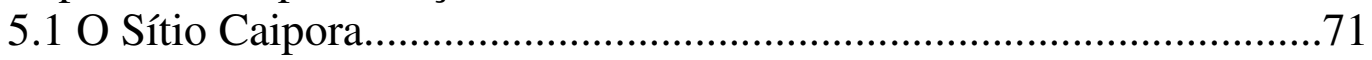

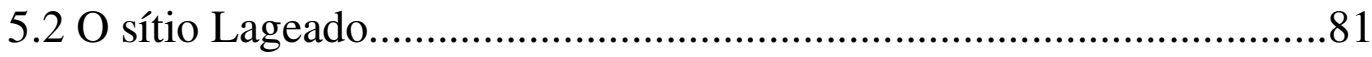

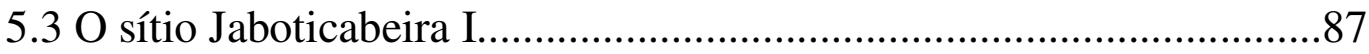

5.4 Levantamento das espécies presentes nos sítios e seus habitats.........100

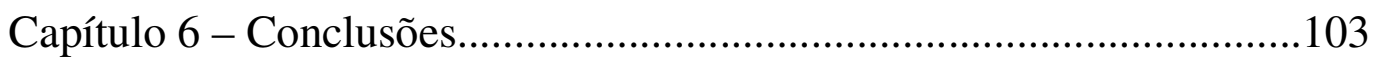

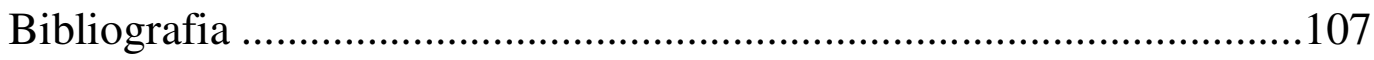




\section{Índice de Tabelas}

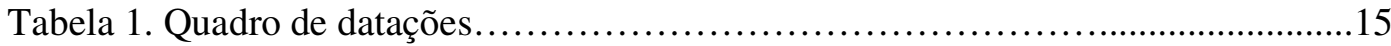

Tabela 2. Sítio Caipora. Componentes da matriz sedimentar Perfil N.....................71

Tabela 3. Sítio Caipora - Perfil NW. Componentes da matriz sedimentar. .................72

Tabela 4 Sítio Caipora Porcentagem dos componentes da matriz sedimentar .............72 Tabela 5. Sítio Caipora Peso inicial (P1) e peso do material triado (P2) do Perfil NW, e suas porcentagens relativas a cada camada..........................................................73

Tabela 6. Sítio Caipora Peso inicial (P1) e peso do material triado (P2) do Perfil N, e suas porcentagens relativas a cada camada...................................................... 74

Tabela 7. Sítio Caipora. Perfil NW. Componentes faunísticos da categoria ossos..........77

Tabela 8. Sítio Caipora. Perfil N. Componentes faunísticos da categoria ossos............ 78

Tabela 9. Sítio Lageado. Porcentagem dos componentes da matriz sedimentar..............81

Tabela 10.Sítio Lageado. Porcentagem dos componentes da matriz sedimentar ...........82

Tabela 11. Sítio Lageado Peso inicial (P1) e peso do material triado (P2), e suas

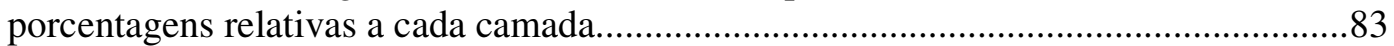

Tabela 12. Sítio Lageado. Componentes faunísticos da categoria ossos......................... 85

Tabela 13. Sítio Jab. I. Componentes da matriz sedimentar do sítio..............................87

Tabela 14. Sítio Jab. I. Componentes da matriz sedimentar do sítio...............................88

Tabela 15.Jab I. Peso inicial (P1) e peso do material triado (P2), e suas porcentagens

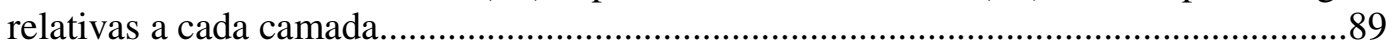

Tabela 16. Jab I. Componentes faunísticos da categoria ossos.....................................92

\section{Índice de Figuras}

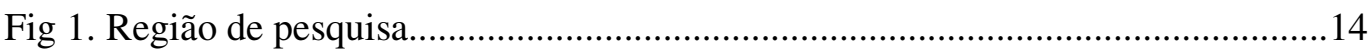

Fig . 2 Mapa geológico da região de pesquisa........................................................21

Fig. 3- Curva da variação do nível marinho proposta por Suguio ...............................24

Fig. 4- Curva da variação do nível marinho proposta por Caruso Jr............................24

Fig 5- Curva da variação do nível marinho proposta por Ângulo..................................25

Fig. 6. Localização dos sítios Caipora e Lageado no momento da máxima transgressão

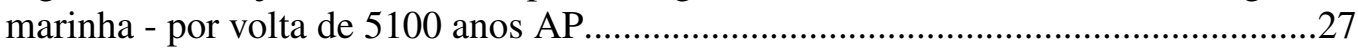

Fig 7 - Mapa geomorfológico da região de pesquisa...................................................30

Fig 8: exploração de conchas do sambaqui Carniça I por volta dos anos 1980 ............31

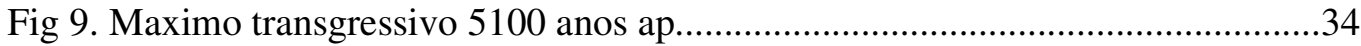

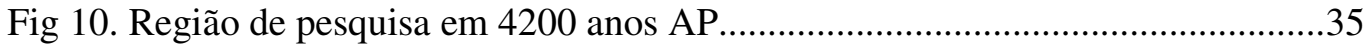

Fig 11. Região de pesquisa em 3700 anos AP..............................................................

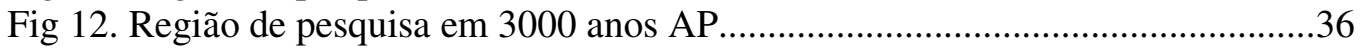

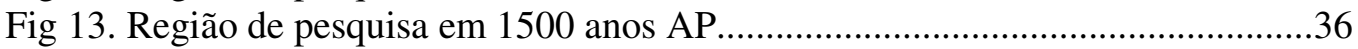

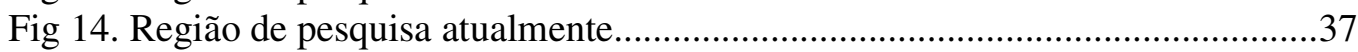

Fig. 15.Material lítico em superfície do sítio Lageado...............................................4

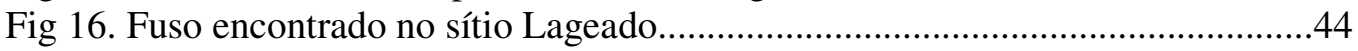

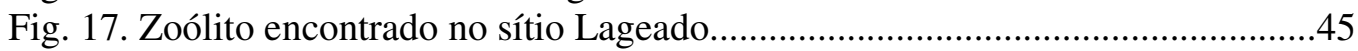

Fig. 18 - Localização dos sítios Caipora e Lageado.......................................................51

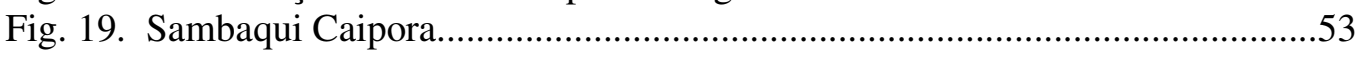


Fig. 20. Coleta zooarqueológica do perfil NW do sítio Caipora.............................54

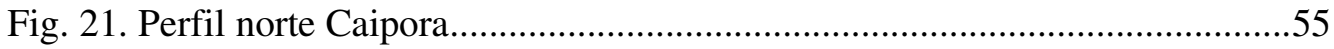

Fig. 22. Sambaqui Caipora Perfil Norte...............................................................56

Fig. 23 Zoólito em forma de pássaro encontrado pelo morador local ao lado de um

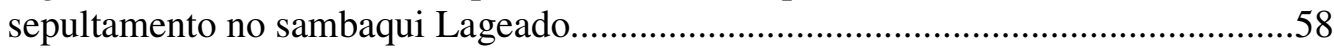

Fig. 24- Artefatos líticos encontrados no sambaqui Lageado..................................58

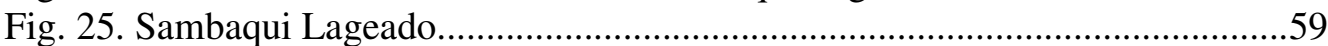

Fig. 26 . Coleta zooarqueológica do perfil E no sambaqui Lageado........................60

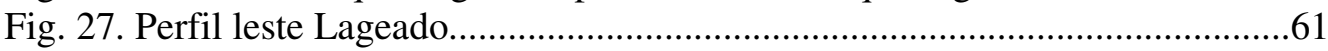

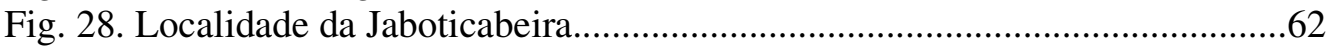

Fig. 29. Perfil oeste do sambaqui Jaboticabeira I.................................................63

Fig 30. Crânio aparente na base do sambaqui (camada 2) cercado por placas de

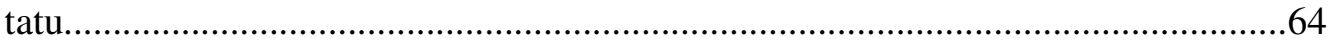

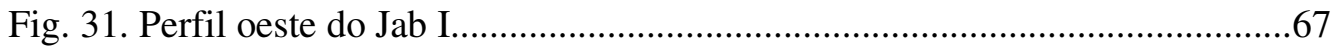

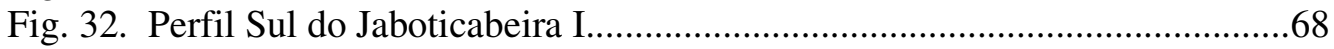

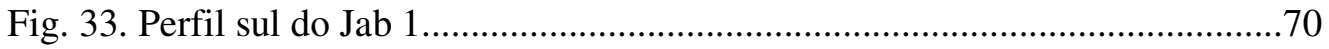

Fig. 34. Porcentagem dos componentes da matriz sedimentar do sítio Caipora ......73

Fig. 35. Sítio Caipora. Porcentagem do Material triado do Perfil N.........................74

Fig. 36. Sítio Caipora. Porcentagem do Material triado do Perfil NW......................74

Fig. 37. Sítio Caipora. Perfil N. Componentes da matriz sedimentar.......................75

Fig. 38. Sítio Caipora. Perfil NW. Componentes da matriz sedimentar.....................76

Fig.39. Sítio Caipora. Perfil NW. Componentes faunísticos da categoria ossos......77

Fig.40. Sítio Caipora. Perfil N. Componentes faunísticos da categoria ossos...........78

Fig. 41. Sítio Caipora. Perfil N. Dimensões das valvas e charneiras de Ostrea sp...79

Fig. 42. Sítio Caipora. Perfil NW. Dimensões das valvas e charneiras de Ostrea sp

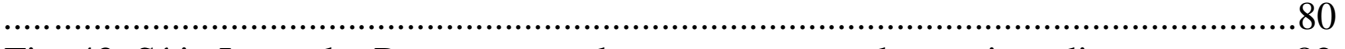

Fig. 43. Sítio Lageado. Porcentagem dos componentes da matriz sedimentar..........82

Fig. 44. Sítio Lageado. Porcentagem do Material triado do sítio..............................83

Fig. 45. Sítio Lageado. Componentes da matriz sedimentar do sítio.........................84

Fig. 46. Sítio Lageado. Componentes faunísticos da categoria ossos.........................85

Fig. 47. Sítio Lageado. Dimensões das valvas e charneiras de Ostrea sp..................86

Fig. 48. Sítio Jab. I. Componentes da matriz sedimentar do sítio..............................88

Fig. 49. Sítio Jab. I. Porcentagem do Material triado do sítio....................................90

Fig. 50. Jab I. Componentes da matriz sedimentar do sítio por camadas...................91

Fig 51. Jab I. Componentes faunísticos da categoria ossos por camadas estratigraficas

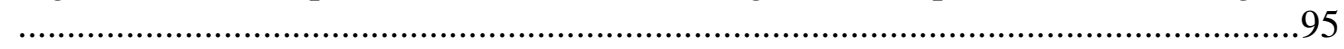

Fig 52. Jab I. Dimensões das valvas de Anomalocardia brasiliana ....................... 96 


\section{Resumo}

O presente trabalho apresenta o estudo das camadas estratigráficas de três sambaquis situados nos municípios de Jaguaruna e Treze de Maio, Santa Catarina, Brasil. Partimos do princípio de que eles são estruturas erigidas intencionalmente por uma população que habitou a região por aproximadamente 6000 anos, e que para a construção de seus cemitérios se apropriavam do material malacológico disponível na região. $\mathrm{O}$ desmembramento dos componentes de cada camada nos forneceu informações a respeito do material construtivo dos sítios, e a partir destes resultados foi possível testar algumas hipóteses sobre a mudança da matriz construtiva verificada nos sambaquis.

Palavras- chave:

sambaqui, estratigrafia, inserção ambiental, caçador-pescador-coletor, variação do nível do mar.

\section{Abstract}

This work presents the study of stratigraphical layers of three sambaquis located on Jaguaruna and Treze de Maio, Santa Catarina, Brazil. We assume that such structures were intentionally built by a population that inhabited the region for over 6000 years, and that for the pilling up of their burial grounds they gathered malacological material available within the area. The breakdown of the elements of each layer provided us information regarding the construction material of the sites, and based on these results it was possible to test some hypothesis regarding a change on the constructive matrix recorded on the sambaquis.

Keywords:

Sambaqui - stratigraphy - environmental setting - fishers-hunters-gatherers - sea level changes. 


\section{INTRODUÇÃO}

Sambaquis são sítios arqueológicos compostos basicamente de material faunístico (conchas, ossos de mamíferos e peixes), apresentando na maioria das vezes forma monticular de base arredondada, e tamanho variado, padrão este recorrente nos sambaquis do litoral sul de Santa Catarina. Podem ser encontrados em boa parte da costa sul-sudeste brasileira, principalmente em regiões lagunares-estuarinas e áreas recortadas de baías e ilhas.

A definição de sambaqui realizada pelo PRONAPA afirma que estes "são sítios arqueológicos cuja composição seja predominantemente de conchas". Prous e Piazza (1977) os definem como sítios que apresentam alta densidade de conchas ( $3 / 4$ do volume da camada arqueológica), com uma espessura de lentes superpostas superior a 1,5m formando um amontoado, que em função de sua altura e forma, se distinguem na paisagem. Gaspar (2000) utiliza o termo sambaqui para caracterizar os sítios localizados à beira de grandes corpos d'água como o mar, rios e lagoas, caracterizando-se por constituir uma plataforma que se destaca na paisagem.

Em Santa Catarina, eles são encontrados principalmente em regiões lagunares e áreas de baías, ilhas e paleoilhas. Seu pacote arqueológico é composto por camadas mais ou menos espessas de conchas intercaladas por numerosos estratos finos e escuros, ricos em materiais orgânicos. São comuns os sepultamentos, presentes em muitos dos sambaquis descritos, e estão normalmente acompanhados de artefatos, oferendas alimentares, fogueiras e festins fúnebres. Este tipo de sítio é caracterizado por um acúmulo de material em sucessivos episódios de construção, normalmente associado a eventos funerários (Bendazzoli, 2007, Klokler 2008). No entanto, temos na região um outro tipo de sambaqui, sem a presença de sepultamentos e compostos por apenas uma ou duas camadas de conchas que recobrem pacotes arenosos (Peixoto, 2008).

Os povos construtores de sambaquis foram por muito tempo caracterizados como pequenos bandos de coletores nômades, que devido aos freqüentes esgotamentos dos bancos de moluscos mais próximos nos quais sua dieta estaria baseada, se deslocariam para bancos seguintes e assim iniciariam a construção de outro sítio. Tempos depois, estes voltariam e reocupariam os primeiros sítios novamente, o que explicaria a complexa estratigrafia destes sítios. Com o aumento do número de trabalhos relacionados a esses povos, essa visão tem sido 
contestada, e eles passaram a ser considerados sociedades com uma densidade demográfica mais expressiva, sedentários, pescadores e consequentemente mais complexos do que o termo "bando" expressa.

Uma interpretação baseada na variação do registro arqueológico presente nos sítios propunha que estes coletores de moluscos teriam se tornado predominantemente pescadores no período tardio de sua ocupação (Andrade Lima, 1991; Prous, 1992, Schimitz, 1987). O fato é que as pesquisas realizadas partiam do pressuposto de que os restos faunísticos fossem derivados puramente da dieta dessas populações. No entanto, em estudos mais recentes (Prous, 1991; Gaspar \& De Blasis, 1992), foi levantada a questão de que além de restos alimentares, os vestígios faunísticos pudessem ter sido utilizados como material de construção dos sambaquis, o que evidenciaria a intencionalidade da construção destes como monumentos ou marcadores territoriais com significação simbólica para seus construtores (Gaspar \& De Blasis, 1992). É partindo deste pressuposto que o presente trabalho se apresenta.

O estudo aqui proposto investiga três sambaquis na região entre Laguna, Jaguaruna e Treze de Maio, denominados Jaboticabeira I, Caipora e Lageado. O primeiro (Jab I) apresenta diferentes conformações em relação aos dois últimos (Caipora e Lageado), em termos de tamanho, inserção no ambiente, material faunístico e cronologia.

Os dados zooarqueológicos estão diretamente relacionados às características ambientais gerais da região e suas constantes mudanças, o que poderia acarretar numa diferenciação da dieta e/ou do material construtivo do sambaqui, que seria comprovada pela mudança do material faunístico encontrado.

A análise zooarqueológica dos componentes das camadas poderá nos trazer informações a respeito de mudanças ambientais ocorridas durante o longo processo de ocupação sambaquieira na região, já que os sítios apresentam diferentes características em sua construção. Pretendemos, portanto, verificar, através do tamanho e freqüência das espécies encontradas se a mudança ocorrida no material de construção do sambaqui pode ter relação aos eventos ambientais.

Esta dissertação pretende realizar um estudo comparativo entre estes sítios no que se refere à implantação na paisagem, captação de recursos e de material construtivo e, desta maneira diferenciar os períodos de ocupação na região baseado na conformação e datação dos sítios, assim como explicar a mudança de material construtivo verificada entre os períodos. 
O presente estudo está vinculado ao projeto temático Sambaquis e Paisagem: Modelando a inter-relação entre processos formativos, culturais e naturais no litoral sul de Santa Catarina, que visa um maior entendimento das sociedades sambaquieiras, e está em vigor desde 1995. Este projeto, coordenado por Paulo DeBlasis, recebeu ajuda de órgãos financiadores como a FAPESP para sua execução.

O capítulo I pretende apresentar uma revisão bibliográfica a respeito das pesquisas em sambaquis no litoral brasileiro, dando ênfase nos sítios do litoral meridional. O capítulo II, a área de pesquisa, a problemática do trabalho, as hipóteses, as justificativas e também o Projeto temático ao qual este trabalho está vinculado. O capítulo III pretende fazer uma apresentação dos sambaquis e da sociedade sambaquieira, a partir dos resultados que o projeto temático apresentou até agora, além de estabelecer uma seqüência cronológica e espacial dos sítios e discutir a variação do NMM (Nível Médio Marinho) e suas implicações na fauna malacológica. O capítulo IV apresenta os sítios estudados, a metodologia e os procedimentos aplicados para o estudo. O capitulo $\mathrm{V}$ apresenta os resultados e a discussão, e o sexto e último capítulo as conclusões alcançadas através do estudo realizado. 


\section{Capítulo I - Revisão Bibliográfica}

\subsection{Pesquisas em sambaquis}

Antes de iniciar propriamente a dissertação, acreditamos ser necessária uma rápida revisão bibliográfica no que concerne a respeito das pesquisas realizadas em sítios do tipo sambaqui no litoral e dos debates que provocaram a intensificação das pesquisas nesses sítios, principalmente no litoral catarinense.

Já no início da colonização portuguesa no Brasil, esses montes de conchas eram mencionados na literatura e utilizados como matéria prima para a fabricação de cal. (Andrade Lima, 1999/2000).

Considerados montes resultantes de deposições naturais por alguns, e resultantes da obra humana por outros, o debate a respeito da artificialidade e naturalidade dos sambaquis ficou em voga por muitos anos. De um lado, os sambaquis eram entendidos como descarte de lixo e de restos de cozinha acumulados sem intenção, e de outro como resultantes do processo de acumulação natural de conchas resultante da regressão marinha pós-diluviana (Andrade Lima, 1999/2000).

Hermann von Ihering foi o principal defensor da teoria naturalista. Segundo ele, teria havido um rebaixamento do continente na linha de costa brasileira, com uma conseqüente transgressão marinha. Ou seja, esses acúmulos monticulares teriam se formado nos fundos marinhos e com o soerguimento da plataforma continental estes depósitos teriam emergido (Ihering, 1907).

Entre os artificialistas, Leão (1919) interpretava os sambaquis como restos de comida, como produto da lassidão do indígena, na qual a intenção de construção era inexistente. Uma terceira corrente de interpretação foi proposta por Karl Wierner (1876), para o qual o sambaqui resultava da conjunção de eventos naturais e artificiais, já que este autor reconhecia que alguns dos acúmulos de concha eram de origem natural e que outros eram artificiais, ou antrópicos. O interessante foi que Wierner considerou os sambaquis artificiais como "obra da paciência humana", acumulados por muito tempo com uma intenção definida, a da construção de monumentos, teoria que mais tarde voltaria a ser levantada. 
Na primeira metade do século XX, a questão da artificialidade ou naturalidade dos sambaquis ainda estava em voga. Leonardos, (1938) publicou uma obra onde ele definia tanto os concheiros naturais como os sambaquis, denominada Concheiros Naturais e Sambaquis. Os concheiros naturais apresentariam depósitos de conchas com valvas quebradas, soltas ou roladas, em camadas alternadas com areia e nos quais não haveria espaço vazio entre as conchas, indicando uma acomodação sob a água. Já os sambaquis seriam os montes circulares ou alongados que se elevam sobre a planície até uma altura de 15 a 20 metros, caracterizados por conter conchas de moluscos comestíveis, sem estratificação regular, com espaços vazios entre as conchas. Além disso, os sambaquis apresentariam cultura material indígena, como os sepultamentos, armas, utensílios domésticos e fogueiras.

Krone, no inicio do século XX realizou uma sistematização dos dados em relação à linha de costa, pensando que os sambaquis mais antigos estariam mais distantes da costa atual, já que o nível do mar àquela época deveria estar mais alto. Também definiu a antiguidade dos sítios através de seu conteúdo malacológico, sendo os sambaquis compostos de ostras mais antigos que os de berbigões (Krone, 1902, 1908).

Por volta da metade do século XX a questão naturalistas $\mathrm{x}$ artificialistas foi encerrada $\mathrm{e}$ os pesquisadores chegaram a um consenso a respeito da artificialidade dos sambaquis. A partir de então, esses sítios passaram a ser objetos de estudos sobre a subsistência das populações sambaquieiras. No entanto, as escavações realizadas no início do século ainda não tinham preocupações metodológicas e científicas, e consequentemente os dados eram pouco confiáveis.

O consenso a respeito da artificialidade dos sambaquis pressupunha esses sítios como produto de sociedades muitos simples, e alguns autores caracterizavam-nas como grupos de famintos que utilizavam a coleta de moluscos enquanto salvação, em um ambiente pobre de recursos (Fróes Abreu, 1932), portanto, os sambaquis não seriam mais do que acumulações de restos alimentares. Dessa maneira ele foi tratado durante muitos anos que se seguiram, como mero acúmulo de lixo.

Nos anos seguintes, escavações sistemáticas em sambaquis com controles estratigráficos foram realizadas. A vinda do casal de arqueólogos franceses Anette Laming Emperaire e Joseph Emperaire ao Brasil resultou na escavação de vários sítios em São Paulo e no Paraná, trazendo as primeiras datações radiocarbônicas para sambaquis. 
Uma nova geração de arqueólogos surgiu, e escavações foram conduzidas nessa época com o objetivo de fornecer dados sobre o ambiente no qual o sítio estava inserido, metodologias de campo, descrições da cultura material encontrada e assim por diante. A coleta de dados passou a ser mais sistemática, tornando possível a comparação de sítios por diferentes grupos de pesquisas.

Uma personagem importante para arqueologia de sambaquis e sua preservação em Santa Catarina foi o padre jesuíta João Alfredo Rohr. Ele foi o responsável pelo levantamento e registro de grande parte dos sítios do litoral do estado, além de agir como defensor do patrimônio cultural, enfrentando até mesmo com armas mineradores que porventura estivessem explorando os sambaquis para extração de conchas.

As pesquisas em sambaquis foram por muitos anos direcionadas pela ecologia cultural, que auxiliou na investigação arqueológica, traçando os estudos para as adaptações das culturas ao meio ambiente. Para tanto, muitas vezes foram utilizados os vestígios faunísticos presentes nos sambaquis. Andrade Lima, (1991) em sua tese de doutoramento, através dos estudos desses vestígios propõe uma mudança na subsistência dos grupos sambaquieiros. Segundo ela, devido ao esgotamento dos bancos de moluscos causado por uma superexploração dos mesmos ligado a um aumento populacional, os construtores dos grandes mounds teriam deixado a coleta de moluscos para trás, e teriam passado a viver baseado na pesca a partir de então, até o seu desaparecimento, ou aculturação através do contato com outros povos que teriam chegado ao litoral tardiamente.

Hurt, em 1974 publica uma obra em que ele conclui que tanto a construção como o abandono dos sítios deveriam estar relacionados com as condições de controle e proteção do ambiente, e utiliza para isso as curvas de nível relativo do mar proposta por Fairbridge. Hurt contou com a colaboração de Bigarella, que já estudava os sambaquis através de um viés ambiental, acreditando que, devido a transgressão marinha, ocorreu um episódio de favorecimento da proliferação de moluscos e consequentemente de ocupação da costa pelas populações sambaquieiras.

Novas perspectivas e maneiras de compreender a sociedade sambaquieira começam a aparecer a partir dos anos 90. A idéia de um padrão de subsistência baseado na coleta de moluscos foi questionada e estudos zooarqueológicos sistemáticos demonstraram claramente que a dieta dos sambaquieiros era baseada na pesca, e não na coleta de moluscos. O exame rigoroso dos sedimentos dos sambaquis, em diferentes sítios, revelou que a presença de 
pescado é mais expressiva na dieta do que a de moluscos, não apenas nas camadas superiores, mas também nas camadas de ocupação mais antigas. (Bandeira 1992, Figuti 1992 e 1993, Figuti \& Klökler 1996, Klökler 2001).

O PRONAPA - Programa Nacional de Pesquisas Arqueológicas, criado na década de 1960, foi um dos responsáveis pelo aumento do número de pesquisas realizadas no país. Seguindo um viés norte americano de trabalho, pesquisadores ligados ao programa enfatizavam a criação de fases e tradições para sítios e cultura material. Pesquisas realizadas em Santa Catarina e no Rio de Janeiro sofreram influencias destes cientistas, resultando em pesquisas que seguiam os princípios do programa.

Beck (1972) estabelece cinco fases culturais para o litoral de Santa Catarina. Ela diferencia as culturas pré-cerâmicas das cerâmicas. As pré cerâmicas estariam distribuídas pelos litoral Norte, Centro e Sul do Estado, enquanto as cerâmicas apareceriam apenas no Norte e Centro. Estudando a diversidade da cultura material encontrada nos sambaquis de Santa Catarina, ela concluiu que as culturas sambaquieiras sofreram influências de diversas outras culturas e que a cerâmica encontrada em alguns sítios estaria relacionada às reocupações do sambaqui por grupos oriundos do interior.

A fase pré-cerâmica da região sul foi denominada de Fase Congonhas e sua classificação foi baseada em que sítios inseridos nesta fase apresentariam grandes dimensões, indústria lítica polida com a presença de zoólitos, e poucos artefatos em ossos e conchas, normalmente associados aos sepultamentos.

Prous e Piazza (1977) também classificaram os sítios em fases, em detrimento da composição malacológica destes. Estes estabeleceram cinco fases das quais três são précerâmicas: Fase Saaguaçú, Saí e Acaraí. A Fase Saaguaçú apresentaria datas mais antigas e estaria relacionada com sítios compostos de mexilhões. A Fase Saí seria menos antigo (médio) e seria composto por ostras e a fase Acaraí apresentaria Anomalocardia como principal material, e seria mais recente do que as outras duas fases. Para o litoral Sul de Santa Catarina ele denominou a fase Garopaba do Sul, que apresenta as mesmas características da fase Congonhas definida por Beck.

Rohr (1969) também estabeleceu cinco diferentes grupos, que ele não chamou de fases, no entanto estabelece diferenças para caracterização destes: 
- Grupo 1 : seriam sambaquis localizados ao longo da linha de praia, e compostos principalmente por Anomalocardia. Apresentam uma razão entre altura e base muito maior que a dos outros grupos.

- Grupo 2: sambaquis localizados mais para o interior da planície do rio Tubarão, compostos de Anomalocardia e ostras, mas principalmente de Anomalocardias. Estariam localizados em encostas ou sobre paleodunas pleistocênicas.

- Grupo 3: sambaquis compostos de mariscos brancos e com cerâmica.

- Grupo 4: sambaquis compostos de conchas de moçambique (Donax sp)

- Grupo 5:sambaquis localizados a vários quilômetros da costa, compostos de ostras e berbigões, estariam semi enterrados.

\subsection{Novas Abordagens}

A partir dos anos 90, abordagens interdisciplinares têm orientado as pesquisas em sambaquis. Bioantropólogos, zoólogos, arqueólogos, geólogos, e geofísicos têm se unido para identificar contextos socioculturais e ambientais, através da interpretação de práticas funerárias e identificação de vestígios habitacionais, além de padrões de assentamento. (DeBlasis et al 1998)

Ultimamente, as linhas de pesquisa em estudos sobre sociedades sambaquieiras têm focado suas questões em complexidade social, monumentalidade, sistemas sócio-culturais únicos para os sambaquieiros, processos de formação dos sítios e padrões de assentamento (Gaspar, 1995; DeBlasis et al 1998).

O estudo do espaço e da identidade cultural dos sambaquieiros vem sendo abordado por pesquisadores como Paulo DeBlasis e Maria Dulce Gaspar, que desenvolvem projetos de pesquisa em Santa Catarina e no Rio de Janeiro. Questões a respeito das formações destes sítios foram retomadas, tendo como foco datações que pudessem estabelecer uma cronologia regional da ocupação sambaquieira. Gaspar (1995) reconhece um único sistema sociocultural para os pescadores-coletores de todo o litoral brasileiro, retomando a perspectiva de Wierner (1876) do sambaqui como monumento, respeitando diferenças locais que obviamente influenciam no modo de vida dessas populações. 
O sambaqui visto como monumento, com um acúmulo intencional de conchas para material construtivo, e não como um acúmulo acidental de restos alimentares foi discutido por arqueólogos e geoarqueólogos (Afonso e DeBlasis, 1994). Compreendemos hoje os sambaquis como construções intencionais, com uma finalidade específica de edificação de um espaço, como marcos espaciais que servem de elemento ideológico para a identificação do grupo (Gaspar, 1991; Klokler, 2001).

Bendazolli (2007) conclui que o sítio Jaboticabeira II é um sítio cemitério e que ele é resultado da união de muitos pequenos monumentos funerários, e que, apesar da aparente homogeneidade do sambaqui visto por fora, ele apresenta um complexo processo que envolve a sobreposição destes pequenos monumentos, evidenciados nos complicados perfis do sítio.

A questão a respeito da mobilidade dos povos sambaquieiros também é alvo das pesquisas mais recentes. Os estudos de Gaspar (1995) apontam a possibilidade de sedentarismo nestes grupos, visto que ocupam áreas ricas em recursos naturais, geralmente em locais de junção de diversos ambientes. De Masi (1999), em sua tese de doutoramento, distinguiu sítios com ocupações permanentes utilizados como base residencial e acampamentos temporários contemporâneos através da análise dos isótopos estáveis de oxigênio, com base na produtividade marinha da Lagoa da Conceição, Florianópolis. Comparou os resultados obtidos de restos esqueletais dos sítios litorâneos, com os de sítios do planalto, e verificou que a dieta destes era à base de recursos terrestres, e não marinhos, o que descarta a possibilidade de movimentos populacionais freqüentes entre as duas áreas. Segundo seu trabalho, os sambaquieiros da ilha de Santa Catarina estariam vivendo lá o ano todo, e não realizariam viagens ao planalto durante determinadas estações.

Em relação a estudos de zooarqueologia em sambaquis, podemos destacar o trabalho de Klokler, (2001 e 2008). Através da análise da fauna e da composição das camadas do sambaqui Jaboticabeira II, a autora indicou uma complexa formação construtiva fundada na elevação do sambaqui em função de diversos processos funerários ligados a festins fúnebres, com oferendas aos mortos. Ainda em relação ao sítio Jaboticabeira II, Belem (2007) e Villagrán, (2007) indicam que o sedimento escuro encontrado no topo de determinadas áreas pode ser produto de remanejamento de áreas domésticas, utilizados como material construtivo para a elevação do sítio.

Temos indícios também de que os grupos sambaquieiros manejavam vegetais e provavelmente praticavam uma espécie de agricultura incipiente. Wesolowski (2000) 
constatou após as análises de séries esqueletais, de diversos sítios do litoral norte do estado de Santa Catarina, na área da Bacia de São Francisco, um alto índice de carboidratos presentes nos esqueletos, resultado do consumo de vegetais.

Calippo (2004) procura entender as rotas migratórias dos sambaquieiros, propondo duas alternativas, uma através do vale do Ribeira e outra através de um litoral que hoje estaria submerso, além de propor nova técnicas de exploração e estudo dos sítios com o mínimo impacto sobre estes, através da utilização de um vibracoring.

Peixoto (2008) analisa sambaquis de pequeno porte na região do litoral sul de Santa Catarina e propõe que estes poderiam estar relacionados a áreas de acumulação e depósito de conchas para o transporte posterior aos sítios funerários.

A compreensão de alguns elementos da sociedade sambaquieira, e de que maneira ela será entendida pela comunidade científica e principalmente pela não científica daqui para frente, dependerá de trabalhos que, cada vez mais se apresentem com metodologias de abordagem mais definidas, no sentido de procurar respostas rápidas e práticas, com as mínimas intervenções possíveis nos sítios. 


\section{Capítulo II - O Projeto e a Problemática de pesquisa}

\subsection{Projeto Sambaquis e Paisagem}

Visando obter um maior entendimento da sociedade sambaquieira e de seu modo de vida, pesquisadores de diversas instituições nacionais e internacionais se uniram para desenvolver o que seria o maior projeto temático já proposto para o estudo dos sambaquis e de seus construtores.

O projeto Sambaquis e Paisagem: Modelando a inter-relação entre processos formativos, culturais e naturais no litoral sul de Santa Catarina criou forma a partir de 1995/1996 com o nome CAP (Camacho Archaeological Project), vindo somente mais tarde a receber o nome atual. Contou, ao longo de seus quatorze anos de vida, com a ajuda financeira de diversas instituições de pesquisa, tanto nacionais como estrangeiras. (portaria IPHAN no. 01510.000047/2003-37, processo FAPESP 04/11038-0).

A área de pesquisa do projeto se concentra na região sul do estado de Santa Catarina e envolve os municípios de Tubarão, Laguna, Jaguaruna, Capivari de Baixo e Treze de Maio, tendo como epicentro o baixo rio Tubarão, e também corpos lacustres e lagunares contíguos. Este projeto partiu da premissa de que os sambaquis não seriam um acúmulo acidental de restos de comida, mas estruturas construídas com uma finalidade específica, e que estes construtores apresentariam uma complexidade social bem maior do que se pensava ate então. A hipótese seria a de que eles apresentariam alta densidade populacional, certa permanência territorial e uma intenção e atividade compartilhada por todos na construção de monumentos, ao menos na região sul de Santa Catarina.

O projeto temático apresenta linhas de investigação que englobam trabalhos geológicos, geofísicos, de educação patrimonial, bioantropológicos, zooarqueológicos, antracológicos, delineando-se um quadro multidisciplinar para investigações arqueológicas. Pretende-se questionar os aspectos da vida e cultura sambaquieira em busca de parâmetros de larga escala para os padrões culturais característicos desta sociedade, incluindo territorialidade e recursos, tecnologia e economia, e organização do sistema de assentamento.

O foco central dos trabalhos é o entendimento das relações espaciais, padrões de assentamento, construção e formação dos sítios. Os pesquisadores concentraram seu estudo a 
princípio em um único sítio, Jaboticabeira II, obtendo mais de trinta datações só para ele, mas perceberam que para compreender um processo regional deveriam direcionar as pesquisas para toda a área. Assim sendo, o projeto pôde contar com intervenções em outros sítios da região, além de levantamentos regionais sistemáticos que duplicaram o número de sítios conhecidos.

Também foram publicados trabalhos com os resultados dos estudos de esqueletos, (Storto et al, 1999), fauna (Klokler, 2001 Barbosa, 2008; Hering, 2005) antracologia (ScheelYbert, 2000, 2001), processos de formação (Bendazolli, 2007 Klokler, 2008), material lítico (Belém, 2007), sedimentologia (Villagrán, 2007), e outros. Dessa maneira, o projeto pôde elucidar questões significativas para o entendimento das sociedades sambaquieiras do litoral sul de Santa Catarina.

\section{2 Área de pesquisa}

\section{Balanço do Patrimônio Arqueológico da Região}

A área de pesquisa contém inúmeros sambaquis de diversas formas e tamanhos, além de sítios associados às culturas Jê, Guarani e caçadores-coletores da tradição Umbu. Trata-se de uma região muito rica em recursos e que abrigou populações indígenas por milhares de anos, com os grupos sambaquieiros sendo aparentemente os primeiros ocupantes da área.

Gaspar e DeBlasis (2001), Kneip (2004) verificaram a existência de agrupamentos de sambaquis na região piloto do projeto, e sugeriram que estes partilhavam seu território, no qual o epicentro estaria a lagoa, o que reforça a idéia de que os corpos d'água lagunares são referência nos padrões de subsistência das comunidades sambaquieiras. 


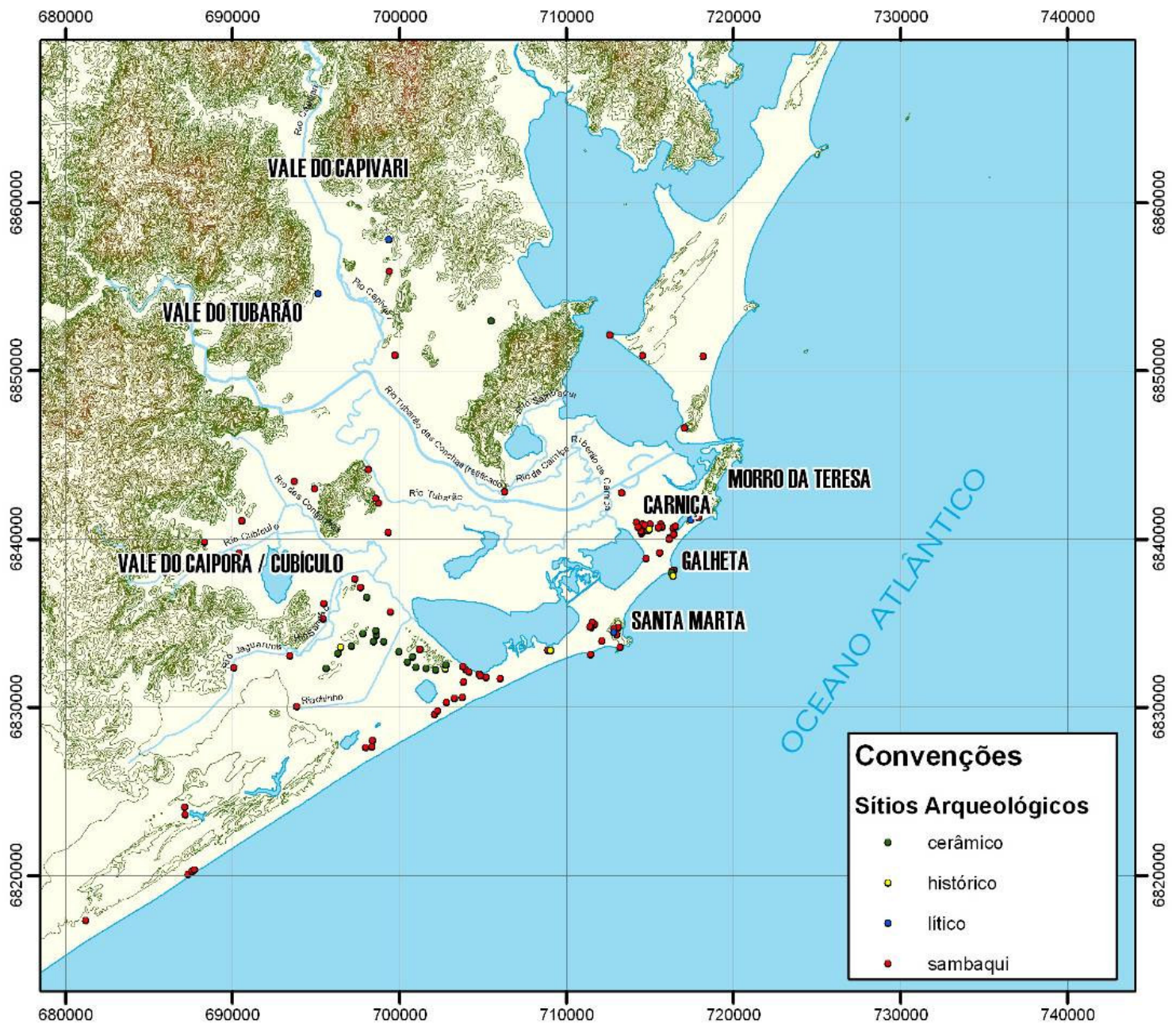

Fig 1. Região de pesquisa

Temos abaixo, a tabela 1 com o quadro de datações de todos os sítios cadastrados da região e nos quais foram retiradas amostras para a datação. 


\begin{tabular}{|c|c|c|c|c|c|}
\hline \begin{tabular}{|r|} 
Sítio \\
\end{tabular} & Código Laboratório & 14C/LOE & AP CAL MIN & AP CAL MAX & OBS \\
\hline Arroio da Cruz I & Beta 209703 & 1080 & 530 & 740 & \\
\hline Arroio da Cruz I & Beta 211732 & 1160 & 640 & 790 & \\
\hline Cabeçuda & Mendonca de Souza 1995 & 4120 & 3930 & 5280 & Extraída da literatura \\
\hline Cabeçuda II & Beta 242800 & 560 & 500 & 630 & \\
\hline Caieira & Isotopes 2624 & 710 & 510 & 760 & \\
\hline Caieira & Isotopes $2628 \mathrm{C}$ & 3230 & 2960 & 3820 & \\
\hline Caieira & Isotopes $2628 \mathrm{~S}$ & 2770 & 2280 & 2740 & \\
\hline Caipora & Beta 234198 & 5410 & 5640 & 5910 & \\
\hline Caipora & Beta 234199 & 6590 & 7320 & 7570 & \\
\hline Canto da Lagoa I & Beta 209706 & 3370 & 3030 & 3400 & \\
\hline Canto da Lagoa II & Beta 234200 & 3500 & 3260 & 3520 & \\
\hline Capivari I & Beta 209705 & 3780 & 3600 & 3840 & \\
\hline Carniça I & A 918 & 3370 & 3170 & 3970 & \\
\hline Carniça I & A 919 & 3370 & 2950 & 3460 & \\
\hline Carniça I & Az 883-2 & 3040 & 2720 & 2930 & \\
\hline Carniça I & Az 884 & 2400 & 2120 & 2720 & \\
\hline Carniça I & $\mathrm{Az} 912$ & 3310 & 2770 & 3480 & \\
\hline Carniça I & Az 914 & 2550 & 1940 & 2480 & \\
\hline Carniça I & Az 917 & 3210 & 2700 & 3380 & \\
\hline Carniça I & Az 950 (956a) & 3275 & 3080 & 3820 & \\
\hline Carniça I & Az 959 & 2460 & 1830 & 2350 & \\
\hline Carniça I & Isotopes 2620 & 3350 & 2900 & 3450 & \\
\hline Carniça I & Lamont 1164 & 3400 & 2860 & 3610 & Extraída da literatura \\
\hline Carniça I & Lamont 1164B & 3300 & 2760 & 3470 & Extraída da literatura \\
\hline Carniça II & Beta 248566 & 3360 & 2990 & 3400 & \\
\hline Carniça III & Beta 248567 & 3360 & 3070 & 3350 & \\
\hline Carniça VI & Beta 248568 & 3800 & 3540 & 3970 & \\
\hline Carniça VII & Beta - 253669 & 3440 & 3190 & 3440 & \\
\hline Carniça VII & Beta - 253670 & 3510 & 3270 & 3530 & \\
\hline Carniça X & Beta 248569 & 2750 & 2320 & 2680 & \\
\hline Congonhas I & Az 10650 & 3165 & 3160 & 3450 & \\
\hline Congonhas I & Az 10651 & 3350 & 3350 & 3820 & \\
\hline Congonhas I & Beck 1972 & 3270 & 2890 & 3950 & Extraída da literatura \\
\hline Congonhas II & Az 10647 & 2740 & 2540 & 2970 & \\
\hline
\end{tabular}




\begin{tabular}{|c|c|c|c|c|c|}
\hline \begin{tabular}{|l|} 
Sítio \\
\end{tabular} & Código Laboratório & 14C/LOE & AP CAL MIN & AP CAL MAX & OBS \\
\hline Congonhas II & Az 10648 & 2705 & 2470 & 2960 & \\
\hline Congonhas II & Az 10649 & 2835 & 2740 & 3200 & \\
\hline Congonhas III & Az 10646 & 2115 & 1890 & 2150 & \\
\hline Costao do Ilhote & Beta 211733 & 980 & 760 & 930 & \\
\hline Cubiculo I & Beta 248575 & 3500 & 3260 & 3520 & \\
\hline Cubiculo I & Beta 248576 & 3640 & 3410 & 3680 & \\
\hline Cubiculo II & Beta -253676 & 3180 & 2810 & 3160 & \\
\hline Encantada I & Beta -262743 & 3930 & 3730 & 4080 & \\
\hline Encantada I & Beta -262744 & 4160 & 4070 & 4410 & \\
\hline Encantada I & CENA 105 LS-24 & 4290 & 4190 & 4610 & \\
\hline Encantada III & Az 10638 & 4420 & 4440 & 4770 & \\
\hline Encantada III & Beta 189712 & 740 & 560 & 720 & \\
\hline Encantada III & Beta 189713 & 4320 & 4640 & 4970 & \\
\hline Figueirinha III & Suguio1988 & 4240 & 3840 & 4820 & Extraída da literatura \\
\hline Galheta I & Beta 209708 & 3090 & 2730 & 3060 & \\
\hline Galheta II & Beta 209709 & 4400 & 4410 & 4770 & \\
\hline Galheta II & CENA 104 LS-10 & 4530 & 4510 & 4880 & \\
\hline Galheta IV & Beta 211734 & 980 & 760 & 930 & \\
\hline Garopaba do Sul & Az 10032 & 2705 & 2150 & 3360 & \\
\hline Garopaba do Sul & Az 9888 & 2840 & 2750 & 3080 & \\
\hline Garopaba do Sul & Beta - 253666 & 3960 & 3820 & 4110 & \\
\hline Garopaba do Sul & CENA LS-25 & 3780 & 3530 & 3910 & \\
\hline Garopaba do Sul & CENA LS-27 & 3780 & 3530 & 3910 & \\
\hline Garopaba do Sul & CENA LS-28 & 4110 & 3960 & 4380 & \\
\hline Garopaba do Sul & Suguio1988 & 3450 & 2850 & 3760 & Extraída da literatura \\
\hline Garopaba do Sul II & Beta - 262747 & 3840 & 3630 & 3960 & \\
\hline Garopaba do Sul III & Beta -262748 & 4100 & 3970 & 4350 & \\
\hline Ilhotinha & Beta 209711 & 5270 & 5480 & 5770 & \\
\hline Ilhotinha & Beta 209712 & 5170 & 5350 & 5660 & \\
\hline Ipoã & Beta - 262746 & 4500 & 4520 & 4830 & \\
\hline Jabuticabeira I & Az 10639 & 4185 & 4430 & 4840 & \\
\hline Jabuticabeira I & Az 10640 & 3995 & 4090 & 4790 & \\
\hline Jabuticabeira I & Az 10641 & 2655 & 2350 & 2920 & \\
\hline Jabuticabeira I & Az 10642 & 2430 & 2130 & 2750 & \\
\hline Jabuticabeira II & Az 10243 & 2365 & 1870 & 2110 & \\
\hline
\end{tabular}




\begin{tabular}{|c|c|c|c|c|c|}
\hline \begin{tabular}{|l|} 
Sítio \\
\end{tabular} & Código Laboratório & 14C/LOE & AP CAL MIN & AP CAL MAX & OBS \\
\hline Jabuticabeira II & Az 10244 & 2490 & 2040 & 2280 & \\
\hline Jabuticabeira II & Az 10245 & 2370 & 1890 & 2100 & \\
\hline Jabuticabeira II & Az 10246 & 2335 & 1850 & 2060 & \\
\hline Jabuticabeira II & Az 10247 & 2795 & 2390 & 2680 & \\
\hline Jabuticabeira II & Az 10631 & 2855 & 2330 & 2820 & \\
\hline Jabuticabeira II & $\mathrm{Az} 10632$ & 2310 & 2040 & 2450 & \\
\hline Jabuticabeira II & Az 10633 & 2890 & 2470 & 2770 & \\
\hline Jabuticabeira II & Az 10634 & 2280 & 1990 & 2420 & \\
\hline Jabuticabeira II & Az 10635 & 2180 & 1880 & 2340 & \\
\hline Jabuticabeira II & Az 10636 & 2655 & 2360 & 2920 & \\
\hline Jabuticabeira II & Az 10637 & 2165 & 1900 & 2310 & \\
\hline Jabuticabeira II & Az 9880 & 2880 & 2770 & 3200 & \\
\hline Jabuticabeira II & Az 9881 & 2075 & 1820 & 2150 & \\
\hline Jabuticabeira II & Az 9882 & 2470 & 2340 & 2700 & \\
\hline Jabuticabeira II & Az 9883 & 2240 & 1820 & 2710 & \\
\hline Jabuticabeira II & Az 9884 & 1805 & 1520 & 1860 & \\
\hline Jabuticabeira II & Az 9885a & 1850 & 1570 & 1860 & \\
\hline Jabuticabeira II & Az 9889 & 2345 & 2010 & 2700 & \\
\hline Jabuticabeira II & Az 9890 & 2285 & 2130 & 2340 & \\
\hline Jabuticabeira II & Az 9891 & 2295 & 1990 & 2480 & \\
\hline Jabuticabeira II & Az 9892 & 1895 & 1350 & 2160 & \\
\hline Jabuticabeira II & Az 9893 & 2210 & 2000 & 2320 & \\
\hline Jabuticabeira II & Az 9894 & 2500 & 2130 & 2850 & \\
\hline Jabuticabeira II & Az 9895 & 2170 & 1890 & 2330 & \\
\hline Jabuticabeira II & Az 9896 & 2170 & 1950 & 2300 & \\
\hline Jabuticabeira II & Az 9897 & 2060 & 1730 & 2290 & \\
\hline Jabuticabeira II & Az 9898 & 2270 & 2000 & 2350 & \\
\hline Jabuticabeira II & Az 9899 & 2115 & 1870 & 2300 & \\
\hline Jabuticabeira II & Az 9900 & 1975 & 1620 & 2110 & \\
\hline Jabuticabeira II & Az AA77105 & 2004 & 1740 & 2000 & \\
\hline Jabuticabeira II & Az AA77106 & 2028 & 1820 & 2040 & \\
\hline Jabuticabeira II & Beta -253672 & 3200 & 2850 & 3160 & \\
\hline Jabuticabeira II & Beta 188381 & 2340 & 2140 & 2430 & \\
\hline Jabuticabeira II & Beta 188382 & 2320 & 2150 & 2350 & \\
\hline Jabuticabeira II & Beta 195239 & 2070 & 1500 & 1810 & \\
\hline
\end{tabular}




\begin{tabular}{|c|c|c|c|c|c|}
\hline \begin{tabular}{|l|} 
Sítio \\
\end{tabular} & Código Laboratório & 14C/LOE & AP CAL MIN & AP CAL MAX & OBS \\
\hline Jabuticabeira II & Beta 195240 & 2020 & 1820 & 2030 & \\
\hline Jabuticabeira II & Beta 195249 & 1970 & 1730 & 1970 & \\
\hline Jabuticabeira II & Beta 195250 & 1950 & 1630 & 2000 & \\
\hline Jabuticabeira II & Beta 228506 & 1550 & 1300 & 1520 & \\
\hline Jabuticabeira II & Beta 228507 & 1930 & 1630 & 1970 & \\
\hline Jabuticabeira II & Beta 234201 & 1400 & 1180 & 1330 & \\
\hline Jabuticabeira II & UW1410 & 2530 & 2230 & 2830 & $\begin{array}{l}\text { Valores respectivamente: LOE, } \\
\text { Desvio mínimo e máximo }\end{array}$ \\
\hline Jabuticabeira II & UW1411 & 1990 & 1800 & 2180 & $\begin{array}{l}\text { Valores respectivamente: LOE, } \\
\text { Desvio mínimo e máximo }\end{array}$ \\
\hline Jabuticabeira II & UW1412 & 2760 & 2440 & 3080 & $\begin{array}{c}\text { Valores respectivamente: LOE, } \\
\text { Desvio mínimo e máximo }\end{array}$ \\
\hline Jabuticabeira II & UW1413 & 2120 & 1920 & 2320 & $\begin{array}{l}\text { Valores respectivamente: LOE, } \\
\text { Desvio mínimo e máximo }\end{array}$ \\
\hline Jaguaruna I & Beta 209707 & 3080 & 2700 & 3080 & \\
\hline Lageado I & Beta 248577 & 5470 & 5690 & 5980 & \\
\hline Lagoa dos Bichos I & Beta 248572 & 4320 & 4260 & 4630 & \\
\hline Lagoa dos Bichos II & Beta 234204 & 4070 & 3950 & 4270 & \\
\hline Lagoa dos Bichos III & Beta 248573 & 4130 & 4010 & 4380 & \\
\hline Lagoa dos Bichos IV & Beta - 253671 & 2040 & 1480 & 1750 & \\
\hline Laguna & Beta - 262749 & 3550 & 3330 & 3570 & \\
\hline Laguna & Beta - 262750 & 1490 & 1290 & 1400 & \\
\hline Laranjal I & Beta - 262745 & 4500 & 4520 & 4830 & \\
\hline Laranjal IV & Beta - 262751 & 440 & 330 & 520 & \\
\hline Mato Alto I & Az 10643 & 2245 & 2010 & 2340 & \\
\hline Mato Alto I & $\mathrm{Az} 10644$ & 2535 & 2130 & 2920 & \\
\hline Mato Alto II & Az 10645 & 4685 & 4870 & 5640 & \\
\hline Monte Castelo & Beta 209715 & 3240 & 2860 & 3260 & \\
\hline Monte Castelo & Beta 209716 & 3360 & 3010 & 3380 & \\
\hline Morrinhos & Beta 209713 & 3230 & 2850 & 3250 & \\
\hline Morrinhos & Beta 209714 & 4480 & 4500 & 4820 & \\
\hline Morro Azul & Beta 190468 & 4480 & 4500 & 4820 & \\
\hline Morro Bonito I & Beta - 262753 & 520 & 340 & 620 & \\
\hline Morro Bonito II & Beta -262754 & 430 & 320 & 510 & \\
\hline Morro Bonito III & Beta -262755 & 510 & 470 & 550 & \\
\hline Morrote & Az 9886 & 2075 & 1720 & 2310 & \\
\hline
\end{tabular}




\begin{tabular}{|c|c|c|c|c|c|}
\hline Sítio & Código Laboratório & 14C/LOE & AP CAL MIN & AP CAL MAX & OBS \\
\hline Morrote & Az 9887 & 1975 & 1570 & 2140 & \\
\hline Porto Vieira I & Beta 209710 & 3610 & 3350 & 3680 & \\
\hline Ribeirao Pequeno & Beta 209704 & 2390 & 1850 & 2230 & \\
\hline Santa Marta I & Beta 195242 & 3200 & 2840 & 3190 & \\
\hline Santa Marta III & Beta - 262742 & 4040 & 3880 & 4240 & \\
\hline Santa Marta III & Beta 195243 & 4110 & 3990 & 4330 & \\
\hline Santa Marta IV & Beta 234194 & 2620 & 2150 & 2440 & \\
\hline Santa Marta IV & Beta 234195 & 2530 & 2070 & 2320 & \\
\hline Santa Marta IX & Beta 248570 & 4670 & 4780 & 5030 & \\
\hline Santa Marta V & Beta 234196 & 2090 & 1540 & 1800 & \\
\hline Santa Marta V & Beta 234197 & 1990 & 1740 & 1990 & \\
\hline Santa Marta VI & Beta -253667 & 3510 & 3300 & 3510 & \\
\hline Santa Marta VIII & Beta - 253668 & 1710 & 1420 & 1690 & \\
\hline Santa Marta X & Beta 248571 & 5240 & 5440 & 5760 & \\
\hline Sibelco & Beta - 262752 & 550 & 460 & 640 & \\
\hline
\end{tabular}

Tabela 1. Quadro de datações 


\subsection{Aspectos físicos}

Partimos do princípio de que o meio influencia o modo de vida das populações que nele vivem, e que, como cientistas, devemos estar conscientes de que a paisagem ( no sentido de paisagem natural) é dinâmica, está em constante mutação, e que o cenário visto hoje em dia por nós não representa necessariamente o mesmo ambiente que as populações pré-históricas estariam vivendo e dela se apropriando, ainda mais em se tratando de áreas litorâneas, na qual a dinâmica de transformação é mais intensa.

A região estudada abrange parte dos municípios de Laguna, Tubarão, Jaguaruna, Capivari de Baixo e Treze de maio. Ela é caracterizada por uma área litorânea limitada pela Serra do Mar e pelo Oceano (Kneip, 2004). A Serra do Mar por sua vez, é formada por terrenos cristalinos que por vezes avançam em direção ao oceano. A área piloto faz parte de uma "zona quaternária extremamente aplainada onde ocorre um conjunto de lagos e lagunas integradas por canais e zonas turfosas encharcadas, sendo as maiores as lagunas de Garopaba do Sul, Camacho e Santa Marta”. (DeBlasis et al, 2007 p. 32) Esta área exibe um grande número de sambaquis. A região de estudo é banhada pelas bacias hidrográficas do rio Tubarão e dos rios Capivari e Cubículo, além de inúmeros lagos e lagunas.

A principal bacia do sistema de drenagem é a do Rio Tubarão, que pode ser caracterizado como um rio de planície, pois em sua porção inferior ele formava meandros que cortavam esses terrenos caracterizados como tais (Caruso Jr, 1995). Hoje em dia, estes meandros são poucos devido à retificação do rio. Ela é a segunda maior bacia fluvial da região costeira de Santa Catarina e alimenta diversas lagunas da região.

As Unidades Geológicas que compõe a região se dividem em dois sistemas: Os leques aluviais e a Laguna-Barreira. Os leques aluviais se situam mais para o interior e abrange as fácies proximais de encostas e canais meandrantes. A Laguna-Barreira é composta por fácies deltáicas, praias marinhas, lagunares e eólicas. (Caruso Jr, 1995).

Encontra-se nesta região um intricado "mosaico de processos deposicionais lagunares, eólicos, e marinhos interdependentes, definidas, no sentido de Walker (1976), como materializações de processos sedimentares específicos" (DeBlasis et al, 2007 p. 34). Processos estes descritos por Giannini como sistemas deposicionais interatuantes: lagunar, barra-barreira, planície costeira (strandplain) e eólico (Giannini 1993, 2001). O sistema lagunar holocênico abrange, de norte para sul, um conjunto de lagunas intercomunicáveis entre Imbituba e Jaguaruna e uma série de lagos residuais de antigas lagunas que comunicam- 
se com o mar aberto através de duas desembocaduras, a da Barra de Laguna e a do Camacho (DeBlasis et al, 1998)

A área das pesquisas concentra-se no sistema lagunar, no entorno das lagunas de Santa Marta, Camacho e Garopaba do Sul e no contato com as serras que emolduram a planície litorânea.

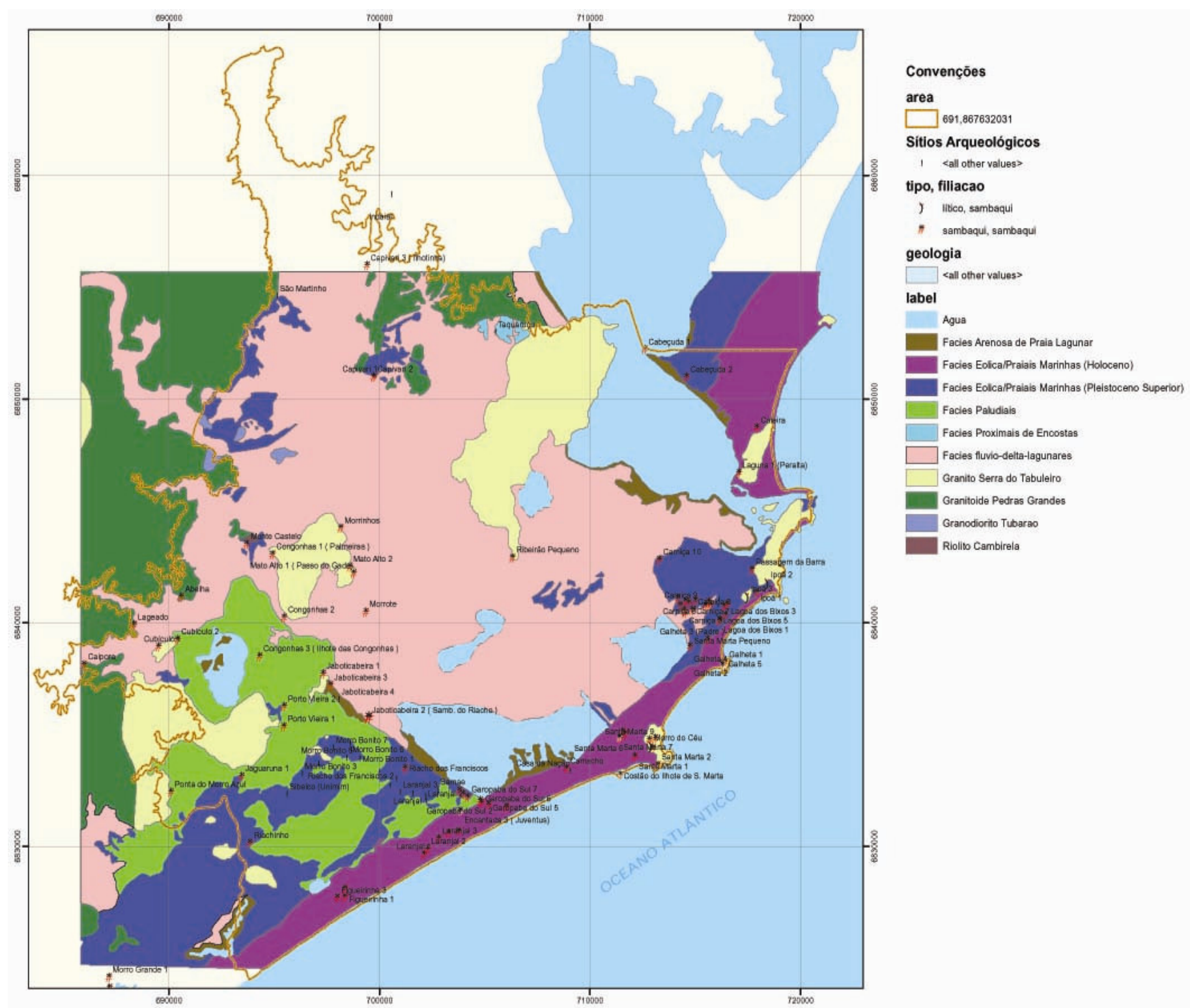

Fig . 2 Mapa geológico da região de pesquisa 


\subsubsection{Clima e Vegetação}

A região de estudo se situa na Zona Subtropical Sul, com o clima podendo ser classificado como tipo "Cfa" - clima subtropical úmido sem estação seca e com verão quente (Nimer, 1989). As temperaturas médias variam entre $23^{\circ}$ no verão, e $14^{\circ}$ no inverno: sendo a média anual de $19^{\circ}$ e com umidade relativa de aproximadamente $85 \%$. (Orselli, 1986)

Segundo o Atlas de Santa Catarina (GAPLAN /SC, 1986) a vegetação da região é composta por Florestas Ombrófilas Densas, que corresponde a uma floresta de planície litorânea e da encosta da Serra do Mar.

A vegetação litorânea sofre influência do oceano e de variações relativas ao solo, o que eu lhe confere aspectos variados e típicos de acordo com diferentes habitats. Na região de pesquisa, a vegetação está inserida no domínio da mata atlântica, que apresenta duas fitofisionomias principais que diferem principalmente em relação a altitude: Restinga e Floresta Atlântica.

A restinga caracteriza-se por diversos agrupamentos e associações de influência flúvio-marinha e condições do solo, tais como ambientes vasosos, rochosos, arenosos e lagunares. Já a Floresta Atlântica apresenta composição florística variada, com grande heterogeneidade, e ocorrem em ambientes com a ausência de um período seco e com temperaturas médias acima de 15 graus (Bianchini, 2008).

Nas áreas mais planas próximas ao litoral, existe a ocorrência de vegetação de restinga baixa, com espécies de porte arbustivos que ocorrem em áreas de dunas. Há a predominância de gramíneas, e juncos em áreas mais alagadiças próximas às lagoas.

Grandes mudanças ambientais ocorreram na região, como por exemplo a variação do nível do mar, na qual a paleolaguna deu lugar, devido a formação de uma barreira arenosa transgressiva, aos diversos corpos d'água menos salgados.

A vegetação, conforme o recuo da lagoa, se expandiu em direção leste-oeste. A análise antracológica realizada no JAB II demonstra que não houve variações significativas da vegetação ao longo do período de atividade do JAB II, e esta permanece parecida com a vegetação atual.

Segundo Bianchini (2008) a restinga dominava o entorno do sítio Jabuticabeira II, podendo ser dividida como restinga arbustiva aberta, restinga arbustiva fechada e mata de restinga. Ainda segundo a autora, a vegetação encontrada na região no período de ocupação 
dos sítios apresenta características semelhantes às encontradas atualmente no entorno das lagoas do camacho e garopaba.

A vegetação de restinga é rica em recursos alimentares - leguminosas com sementes comestíveis, espécies frutíferas - Myrtaceae, Anacardiaceae, Cactaceae, Bromeliaceae, Sapotaceae, entre outras. - estão presentes no registro arqueológico do sambaqui Jaboticabeira II estudado por Bianchini. Tubérculos também aparecem no registro, os quais, pelo fato de serem ricos em amido, podem ter sido os responsáveis pela presença de cáries nos esqueletos.

\subsubsection{Variação do Nível do Mar}

A relação entre a variação do nível do mar e os sítios tipo sambaqui atraiu a atenção de diversos pesquisadores. Os sítios situados mais distantes da linha de costa atual foram classificados como mais antigos por Krone, já no início do século XX.

Estudos realizados ao redor do mundo tentaram criar uma curva de variação do nível do mar que abrangesse a totalidade dos oceanos, no entanto, estes trabalhos mostraram que uma única curva não daria conta de averiguar a variação ao longo das costas mundiais e que, portanto este tipo de avaliação só seria possível construindo-se curvas locais ou regionais (Kneip, 2004).

É sabido que diversas transgressões e regressões marítimas ocorreram desde antes do período quaternário, mas para este estudo iremos discutir apenas as que ocorreram no Holoceno, período em que os sambaquis estiveram em atividade. Segundo Kneip (2004), a última transgressão marinha foi determinada a partir de amostras de carbono 14, coletadas em toda a costa brasileira.

Para Suguio et al, (1985) a curva proposta para o litoral catarinense contém as seguintes propriedades: há aproximadamente 6500 anos AP o nível do mar estaria ultrapassando o atual nível zero, alcançando a máxima transgressão (provavelmente 3,5 m acima do zero atual) em torno de 5100 anos AP, voltando a regredir para abaixo do zero atual entre 4100 e 3800 AP, para novamente subir por volta de 3600 AP e de novo cair entre 2900 AP. Em 2500 AP ele teria voltado a subir acima dos $2 \mathrm{~m}$ do atual zero, para descer continuamente até o nível de hoje, revelando dois episódios de abaixamento seguido de levantamento do nível do mar. 


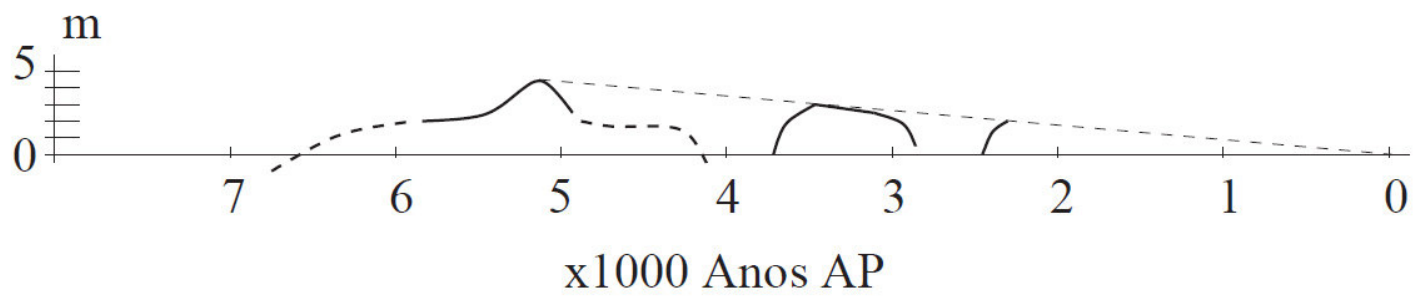

Fig. 3- Curva da variação do nível marinho proposta por Suguio Fonte: Kneip (2004)

Caruso Jr. (1995) discorda desta curva e propõe outra baseada em estudos com dados retirados dos sambaquis Ponta das Almas (Piazza, 1966 b, e Hurt, 1974) na ilha de Santa Catarina e o sambaqui Carniça I (Hurt, 1974) na região de Laguna. Para ele, a máxima transgressão teria ocorrido por volta de 5200 anos AP e teria regredido continuamente até uma brusca queda em 3000AP, a qual teria deixado o nível do mar abaixo do zero atual, voltando a subir em 2500 AP. Esta transgressão teria durado até 1380 +/- 70 anos e teria atingido 2,0 m acima do nível atual. O movimento regressivo subsequiente não é bem caracterizado, podendo ter sido constante até o zero de hoje ou podendo ter ocorrido mais um rebaixamento seguido de outra transgressão que alcançaria o nível atual.

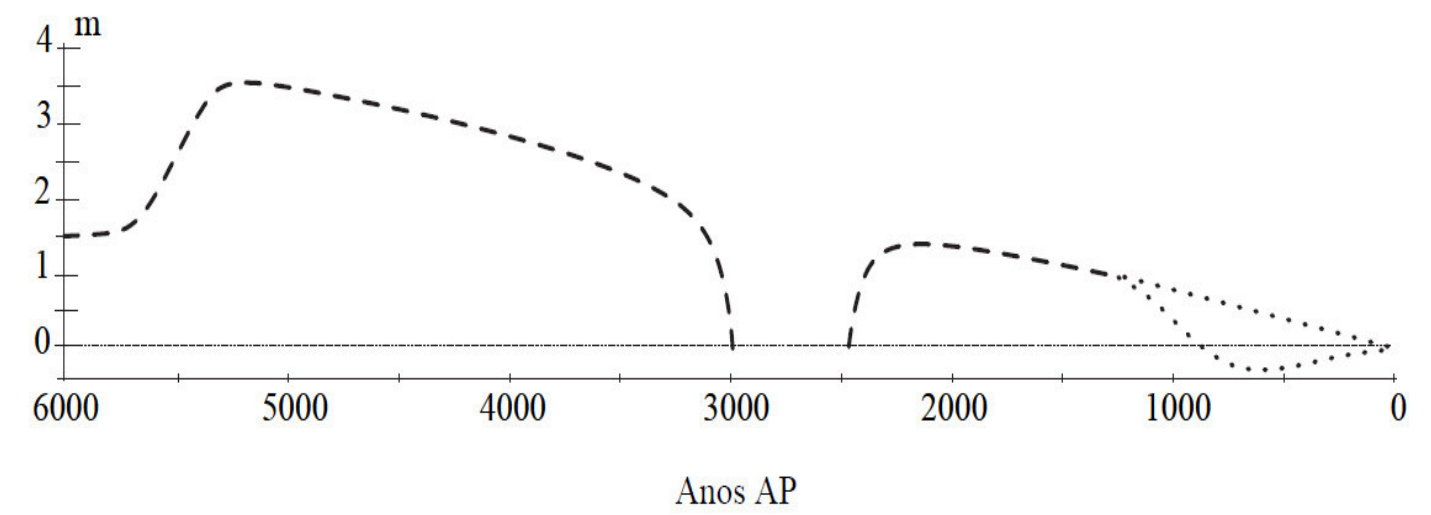

Fig 4- curva da variação do nível marinho proposta por Caruso Jr Fonte: Kneip (2004)

A curva realizada por Angulo et al (1999) foi realizada com uma série de dados para o litoral próximo a Laguna, baseados na determinação da idade das amostras de tubos fósseis de vermetídeos e sua posição relativa ao nível médio marinho atual. Neste caso, ele não encontra evidências de regressão que causasse um abaixamento do nível do mar mais baixo 
que o atual em nenhum momento, com a máxima transgressão por volta dos 5000 anos e uma regressão contínua até os dias atuais.

As três curvas apresentadas neste trabalho foram retiradas da tese de doutoramento de Kneip, 2004.

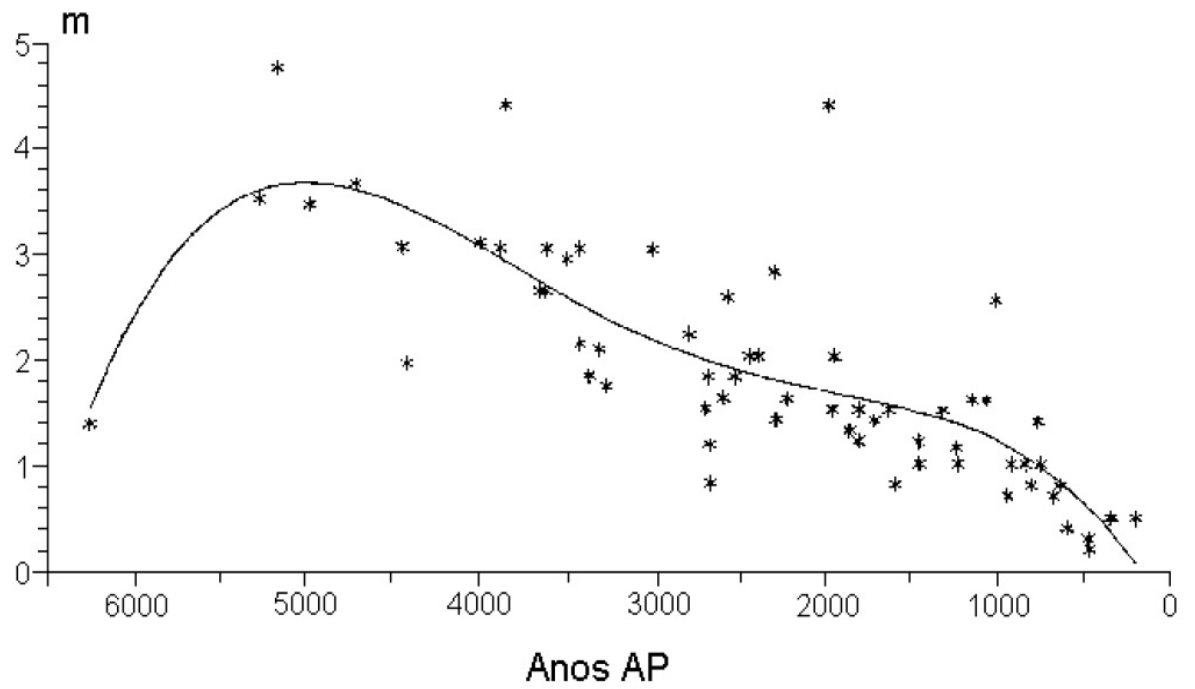

Fig 5- Curva da variação do nível marinho proposta por Ângulo. Fonte: Kneip (2004)

Dado que a variação do nível do mar ocorreu de fato, assumimos que a mudança da paisagem na região variou significantemente, já que a região em estudo é composta por uma planície quaternária baixa, onde qualquer elevação do nível do mar acarretaria na inundação de uma extensa área, modificando profundamente a paisagem. Com a máxima transgressão marítima a área em questão configurava uma grande laguna chamada paleo laguna da Santa Marta. Com posterior regressão e a diminuição do nível médio das águas, formou-se o sistema lagunar semelhante ao que observamos hoje (Kneip 2004).

Este evento teria inundado áreas de grande extensão, mas de pouca profundidade, permitindo assim a formação de um ambiente ideal para a proliferação da fauna malacológica. É importante observar que o desenvolvimento da fauna malacológica está estreitamente ligado à formação de lagoas. Elas são pouco profundas, com as águas relativamente mais quentes e de baixa salinidade, favorecendo a proliferação dos moluscos que encontravam aí um habitat ideal (Beck, 1972). 
Este trabalho apresenta dados que não se encaixam em nenhuma das curvas propostas pelos autores. Ao analisar as datas do sambaqui Caipora que encontra-se muito próximo aos patamares da Serra Geral, verificamos uma idade muito recuada, de 7500 AP, onde, segundo as curvas apresentadas o nível do mar estaria próximo ao nível atual. No entanto, as curvas foram realizadas com variações de 40 metros, portanto há uma margem de erro relativamente grande, o nos leva a crer que é possível que no momento da construção do sambaqui Caipora o nível da água estivesse alcançando a base do sítio. Pensamos desta maneira porque consideramos a população sambaquieira como uma população que está voltada para os recursos aquáticos, principalmente para as lagoas e baías da região. É de se esperar que mesmo os sambaquis mais antigos apresentassem uma localização na qual a paleo lagoa estivesse contígua. Com relação ao Lageado, as curvas estão de acordo, e o sambaqui estaria situado às margens da paleolagoa no momento de máxima transgressão marinha. 


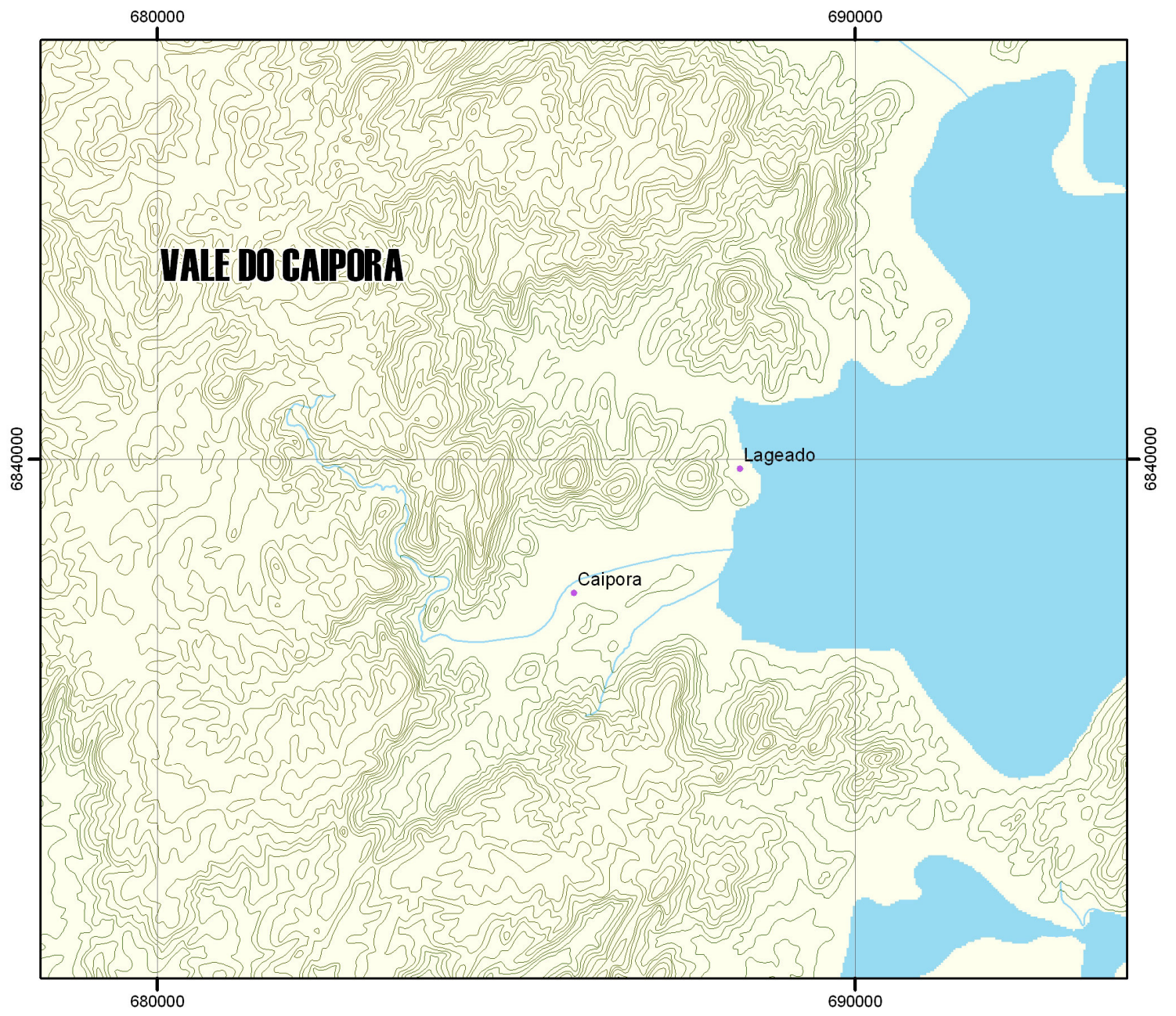

Fig. 6. Localização dos sítios Caipora e Lageado no momento da máxima transgressão marinha - por volta de 5100 anos AP.

\subsection{Problemática}

A ocupação do litoral sul de Santa Catarina por populações sambaquieiras vem de longa data. Aparentemente estas populações se instalaram na região por volta de 7500 anos AP e lá permaneceram até 1000 anos AP aproximadamente. Uma grande expansão demográfica e espacial teria ocorrido por volta de 4000 anos AP, período em que notamos um aumento expressivo no número e no tamanho dos sítios na região.

O estudo a respeito dos sambaquis e de sua população já apresentou diversos resultados significantes para o entendimento do modo de vida destes. No entanto, algumas questões que concernem a mudanças e continuidades na tradição sambaquieira ainda precisam ser esclarecidas. 
Uma delas é a diferença composicional dos sítios. Retratados como monumentos, esses montes de conchas carregam um significado simbólico para as populações que os construíram. Dessa maneira, ao notarmos que a modificação do material construtivo dos sambaquis ocorreu de fato, precisamos pensar quais as questões que levaram a essa troca de material. As conchas parecem exercer um significado para esses povos, e então, porque a mudança de material ocorre?

De um lado, temos sítios compostos quase exclusivamente de Ostrea, de outro, quase exclusivamente de Anomalocardia, com uma ocupação final de sedimento preto. É sabido que os povos sambaquieiros permaneceram na região por pelo menos 6000 anos, e que estes mantiveram a construção de sítios de conchas por todo esse período, com exceção de um período tardio no qual a terra preta tomou o lugar das conchas na elevação do monumento.

A questão aqui proposta é se as duas mudanças ocorridas (Ostrea sp-Anomalocardia e Anomalocardia - Terra Preta) foram resultantes de implicações ambientais ou humanas. Ou seja, essa mudança teria sido ocasionada por superexploração, por mudanças ambientais como a Variação do Nível Marinho ou poderiam estar relacionadas com contato com outros povos que teriam chegado mais tardiamente na região?

Além disso, este trabalho pretende estabelecer diferentes períodos de ocupação sambaquieira na região, considerando a morfologia dos sítios, tamanho, composição e cronologia.

A Anomalocardia, material construtivo da maioria dos sambaquis encontrados na área de pesquisa, necessita de um ambiente específico para se desenvolver, assim como a Ostrea $s p$. Dessa maneira, tentaremos estabelecer os nichos explorados e as técnicas de captura utilizadas pela população sambaquieira ao longo do período de formação dos sambaquis trabalhados. Para isso, a definição das espécies encontradas, seu habitat e comportamento de cada uma serão descritas.

Os sítios mais antigos aparecem na encosta da Serra e apresentam material construtivo diferente dos mais recentes, localizados mais próximos a linha de costa atual.

Em um primeiro momento, os sítios seriam construídos basicamente de Ostrea $s p$, enquanto mais tardiamente (no momento em que começa a expansão sambaquieira) o material teria sido substituído pela Anomalocardia brasiliana, e ainda mais recentemente a Anomalocardia teria sido substituída como matriz construtiva de alguns sambaquis que estariam em atividade no período, por um sedimento escuro denominado de Terra Preta de sambaquis. 
São duas as hipóteses levantadas por nós, nas quais a explicação para a mudança do material construtivo pudesse ser decorrente da explotação humana dos recursos malacológicos das áreas imediatas aos sítios, ou seria de que as mudanças ambientais ocorridas na região, como por exemplo a redução dos corpos d'água devido a regressão marinha, acarretasse em uma diminuição da oferta de alguns destes recursos e consequentemente a alteração de material construtivo dos sítios.

Segundo Mannino e Thomas (2002), uma exploração acentuada e diária de recursos malacológicos acarretaria, ao longo do tempo, em uma diminuição do tamanho dos espécimens, fato que seria comprovado através do material arqueológico. Os autores crêem que esta forma de predação causaria um desequilíbrio significante nas populações de moluscos.

Estudos realizados por Keogh et al (1993) compararam populações de moluscos em costões rochosos de Victória - Austrália que foram protegidas da exploração forrageira por humanos por setenta anos, com outras de áreas não protegidas de exploração. Eles demonstraram que as espécies exploradas para alimentação eram menos abundantes e apresentavam menor tamanho que as espécies raramente coletadas.

Os critérios para inferir super-exploração de bancos de moluscos, baseados em Classen (1986 e 1998) são:

- Decréscimo das espécies preferenciais de coleta conforme o depósito se desenvolve.

- Diminuição do tamanho das conchas das amostras de base em relação às de topo do depósito.

- Espécies de captura mais difícil crescem em número conforme o depósito aumenta.

- Espécies de processamento mais difícil crescem em número.

- Redução continuada da idade das conchas desde a base até o topo do depósito.

No segundo caso, o de mudança ambiental, é sabido que na região de pesquisa, variações do nível do mar ocorreram nos últimos 7000 anos, sendo que o máximo transgressivo ocorreu por volta dos 5000 anos AP. Nesse caso, a hipótese é de que a mudança do material construtivo mudou de Ostrea sp para a Anomalocardia porque com a contínua regressão, o ambiente necessário para o desenvolvimento da Ostrea sp já não estaria mais 
próximo aos sítios, enquanto que a abundancia da Anomalocardia facilitaria a coleta e o transporte do material até a área a ser depositada.

O fato é que as ostras encontradas nas amostras recolhidas para o presente estudo não apresentam marcas de fixação em raízes, ou seja, elas são provenientes de costões rochosos e não de mangues. A ostra de mangue necessita de água doce misturada a salgada, podendo se desenvolver em ambientes de baixa salinidade, enquanto a ostra de costão se desenvolve na confluência de água salgada e salobra com uma base granitóide. Com a regressão marinha, e a conseqüente formação de lagoas, haveria uma proliferação dos bancos de Anomalocardia, enquanto que as ostras perderiam o habitat ideal para seu desenvolvimento, já que o granito necessário para que ela se fixe não estaria mais em contato com a água salgada.

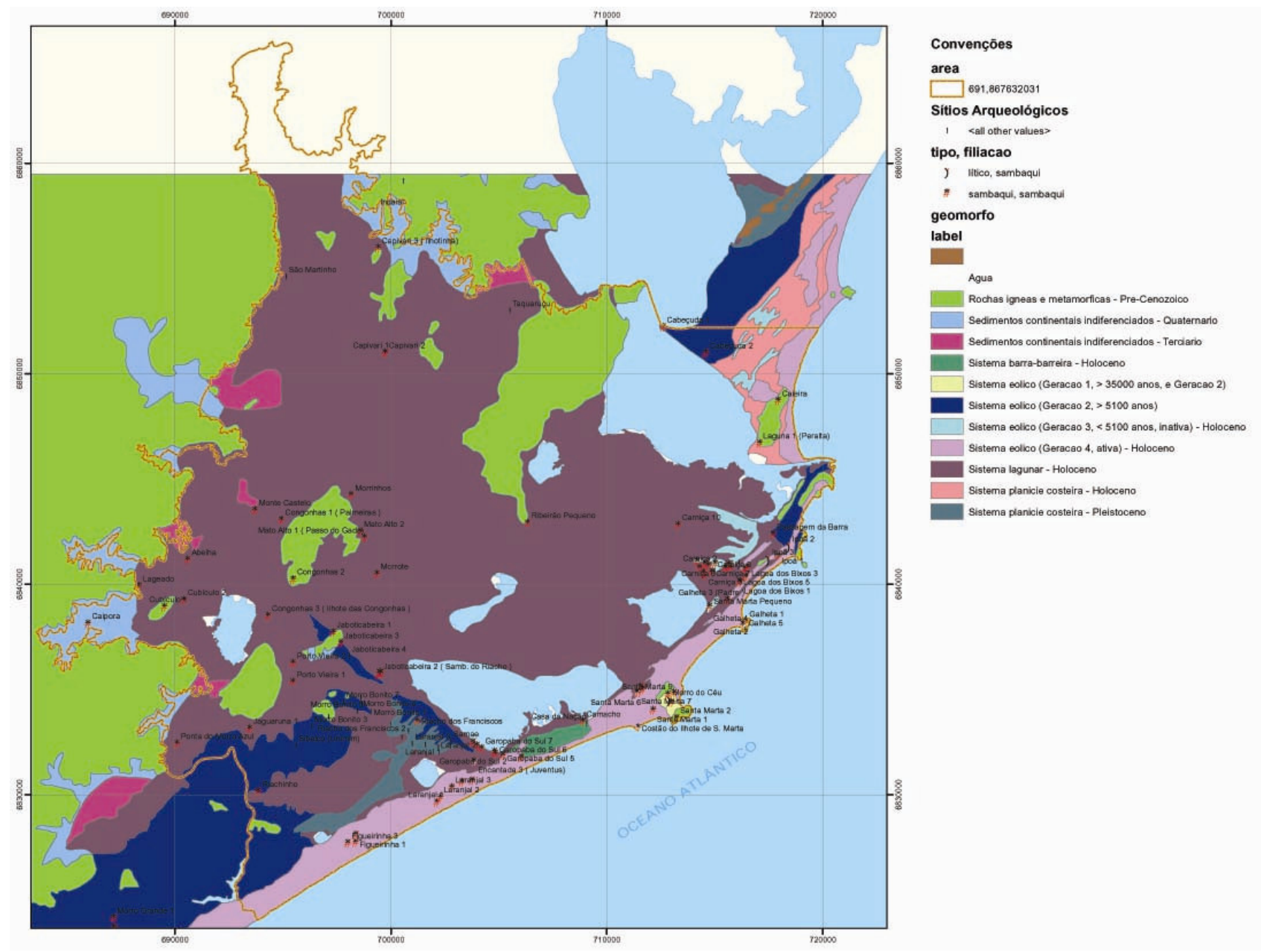

Fig 7 - Mapa geomorfológico da região de pesquisa 


\section{Ocupação atual na área de pesquisa}

A área de pesquisa do projeto temático Sambaquis e Paisagem já apresentou um número elevado de sítios do tipo sambaquis, aproximadamente 100 sambaquis, sendo que a grande maioria destes encontra-se em áreas de ocupação mais recente por colonizadores europeus.

Os sambaquis mais antigos compostos por ostras e de tamanho singelo, se comparado aos grandes sambaquis da área, como os Jaboticabeiras, Carniças e Garopaba por exemplo apresentam-se em menor número. Acreditamos que esse número baixo de sítios ocorre porque, além de uma maior dificuldade de encontrá-los devido ao seu tamanho reduzido, eles podem ter sido destruídos, já que se encontram em áreas de ocupação mais antiga e é sabido que as conchas de sambaquis são utilizados como material de exploração para a fabricação de cal e outros fins desde os primeiros tempos da chegada dos portugueses ao território nacional.

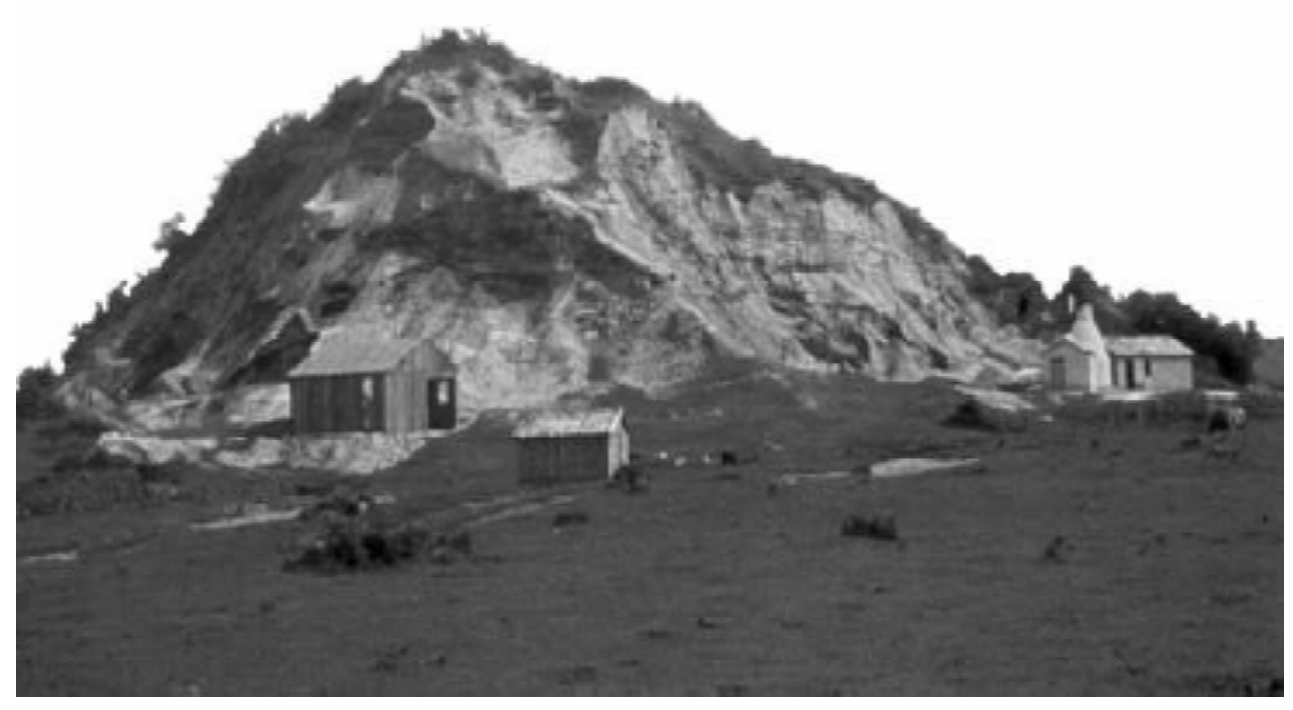

Fig 8: exploração de conchas do sambaqui Carniça I por volta dos anos 1980. 


\section{Capítulo III - Ambiente e sociedade}

A ecologia cultural é definida por Julian Steward (1955) como uma série de princípios, metodologias e conceitos que podem ser aplicados em diferentes condições espaciais e temporais ao estudo do homem, sua sociedade e sua cultura. Ela estuda a rede de relações que existem entre as comunidades e o ambiente em que vivem. Um exemplo é como as sociedades utilizam seu acervo cultural para se adaptar socioculturalmente a condições ambientais particulares. Em outras palavras, trata-se de uma ferramenta metodológica para investigar as causas e conseqüências das constantes transformações das culturas humanas em seu processo de adaptação ao ambiente (Steward, 1955).

Para Stewart, a ecologia cultural se preocupa em verificar o equilíbrio entre o sistema sócio-cultural e o sistema ambiental. Ela estaria preocupada na forma pela qual os sistemas se ajustam ao ambiente total, baseada em três princípios fundamentais: a análise das interrelações entre tecnologia de exploração e/ou produção e o ambiente, padrões de comportamento implicados na exploração de uma área particular por meio de uma tecnologia particular e, na medida em que as formas de conduta envolvidas na exploração do ambiente afetam outros aspectos da cultura.

A Ecologia Cultural pregava que as sociedades simples eram produtos de ambientes pobres, que encorajavam a mobilidade e colocava em cheque a acumulação. A evolução social caracterizava negativamente as sociedades pré-agrícolas, considerando-as como o estágio inicial da evolução humana; em sua visão, o desenvolvimento de instituições ligadas à complexidade se daria passo a passo até que estas alcançassem um modo de vida agricultora, na qual as formas institucionais viriam a emergir com uma produção voltada para tornar o meio rico e seguro. As sociedades caçadoras - coletoras atuais teriam sofrido uma espécie de "involução", no que se refere ao modo de vida social e produtora de bens. Esta é uma afirmação que já foi superada, e as sociedades caçadoras e pescadoras não são mais interpretadas desta maneira.

No caso das sociedades sambaquieiras em questão, é de se supor que o nível de complexidade social alcançada por ela é bem maior do que se pensava até poucos anos atrás (DeBlasis et al, 1998). Na década de 80, Perlman (1980) estudou sociedades pescadoras com base em dois modelos (apud De Masi, 2001). O primeiro baseado em produtividade primária marinha, e o segundo na otimização como resposta as mudanças de produtividade ocorridas 
devido principalmente a variação do nível do mar. Segundo o primeiro modelo, mangues e pântanos se tornaram o nicho mais produtivo em áreas costeiras depois que o nível do mar estabilizou, por volta de 5000 anos atrás. Segundo ele, as áreas mais produtivas são as que mantém mais material em suspensão, como as plataformas continentais rasas com baixo estresse de ondas e zonas estuarinas. O segundo modelo, caracteriza-se pelo menor esforço e risco e pela seleção ordenada dos ambientes, assim, devido às mudanças ambientais, ocorrerá uma mudança das estratégias locais de exploração (De Masi, 1999).

Seguindo os modelos de Perlman, podemos esperar que áreas com alta produtividade apresentem evidências arqueológicas com uso de recursos marinhos, que movimentos populacionais são resultados de área de baixa produtividade e recursos dispersos e que, portanto, em ambientes mais produtivos é esperado um alto grau de sedentarização. Os moluscos só seriam utilizados como alimento em tempos de escassez dos recursos principais (Perlman, apud DeMasi, 1999). Para ele, os grupos costeiros tornaram-se sedentários devido a uma resposta oportunística à alta produtividade destes ambientes unidas a alta densidade populacional.

Para Renouf (1984), o modelo Man, the Hunter (Lee \& Devore, 1968) - proposto na Conferência de Chicago em 1966, que estabeleceu parâmetros para classificação de sociedades caçadoras-coletoras - é inadequado para as sociedades costeiras pescadoras. Este modelo caracterizava as sociedades simples como grupos de caçadores-coletores igualitários, altamente móveis, com baixa densidade de população, falta de territorialidade e fluidez na composição do bando. As características dos grupos estudados por Renouf em regiões costeiras não apresentaram a definição clássica de caçadores-pescadores-coletores estabelecido nesta conferência, mas semelhantes às sociedades produtoras de alimentos. Estas sociedades seriam menos móveis, com alta densidade populacional, limites territoriais definidos e com tecnologia especializada. Dessa maneira, em áreas onde a flutuação de recursos é alta, os assentamentos serão sedentários, e esta redução de mobilidade implicará em outras características sociais do grupo, permitindo um grau de complexidade mais alto. Para ele, as características complexas dos grupos estudados são resultados de condições ambientais específicas e de distribuição de recursos.

A ocupação sambaquieira na região de pesquisa demonstra que existe a presença de estruturas de organização territorial bastante estáveis e articuladas em âmbito regional, com epicentro na laguna. A dinâmica de distribuição de sítios demonstra que o centro dos 
recursos e de realização de atividades cerimoniais estariam distribuídos em torno da área ocupada pela água na época de atividade dos sambaquis.

Segue abaixo a seqüência proposta por Kneip (2004) para a regressão marinha que ocorreu no holoceno, e que influenciou todo um sistema de assentamento das populações sambaquieras que viveram na região durante milhares de anos.

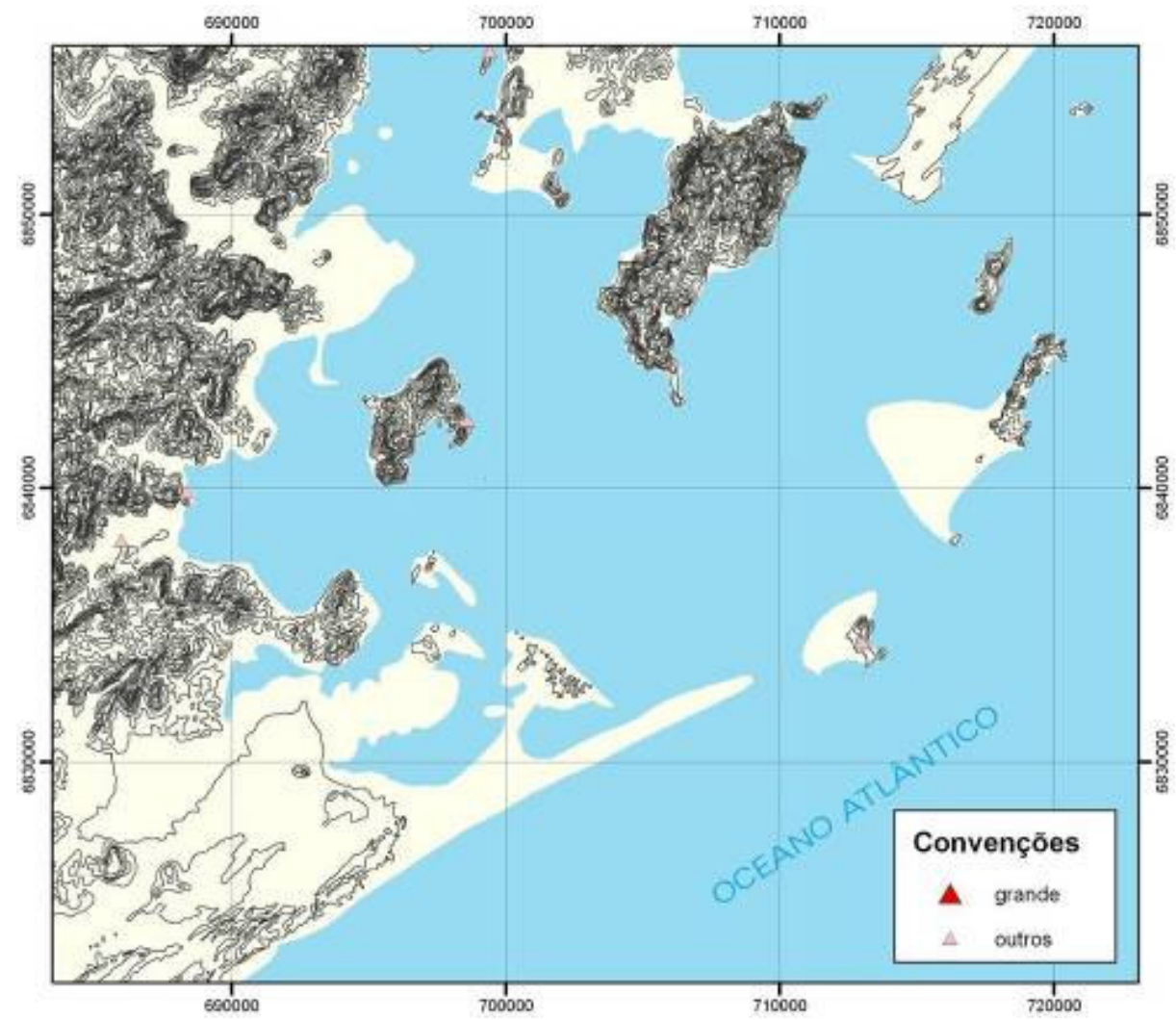

Fig 9. Maximo transgressivo 5100 anos ap 


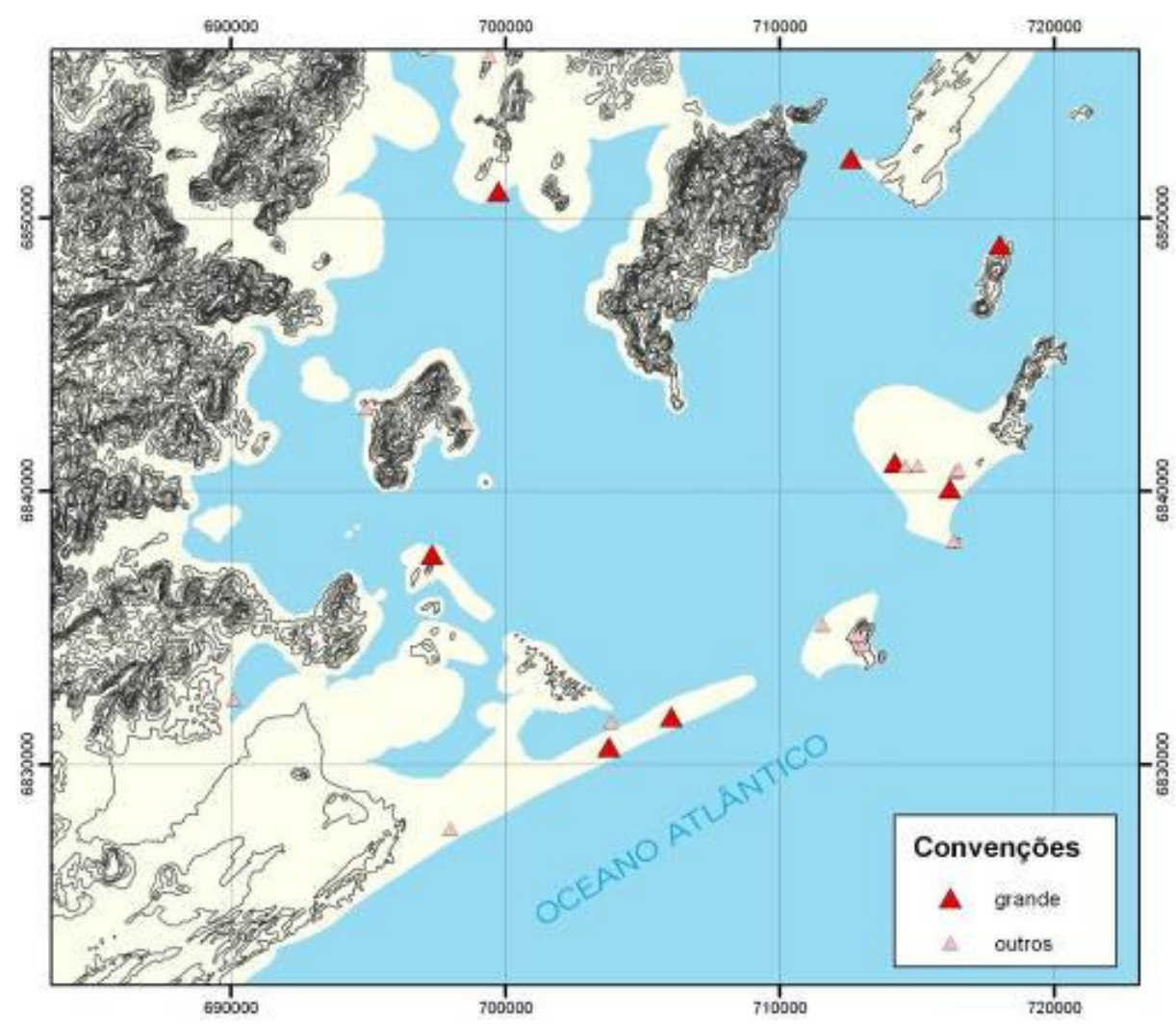

Fig 10. 4200 anos AP

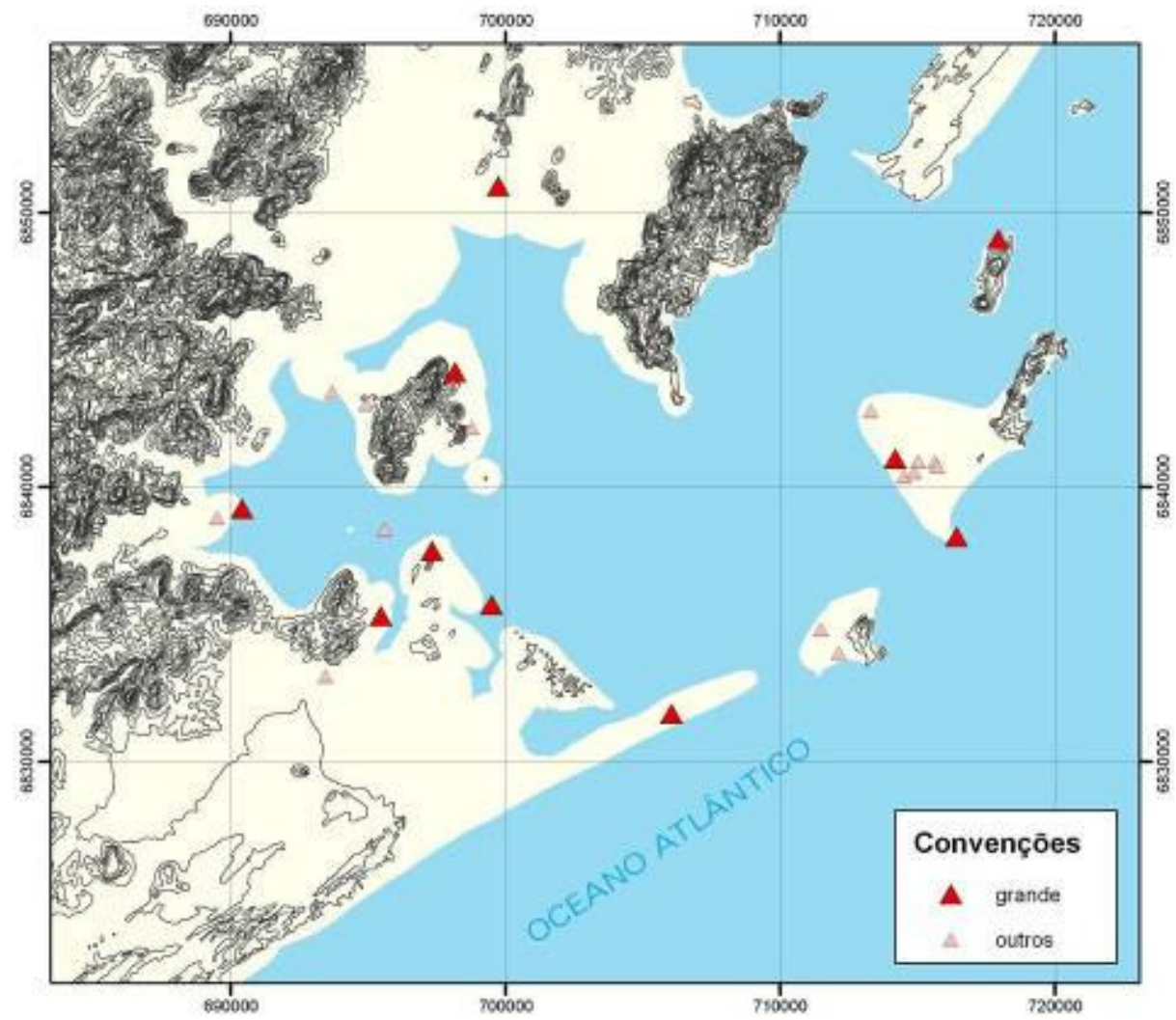

Fig 11. 3700 anos AP 


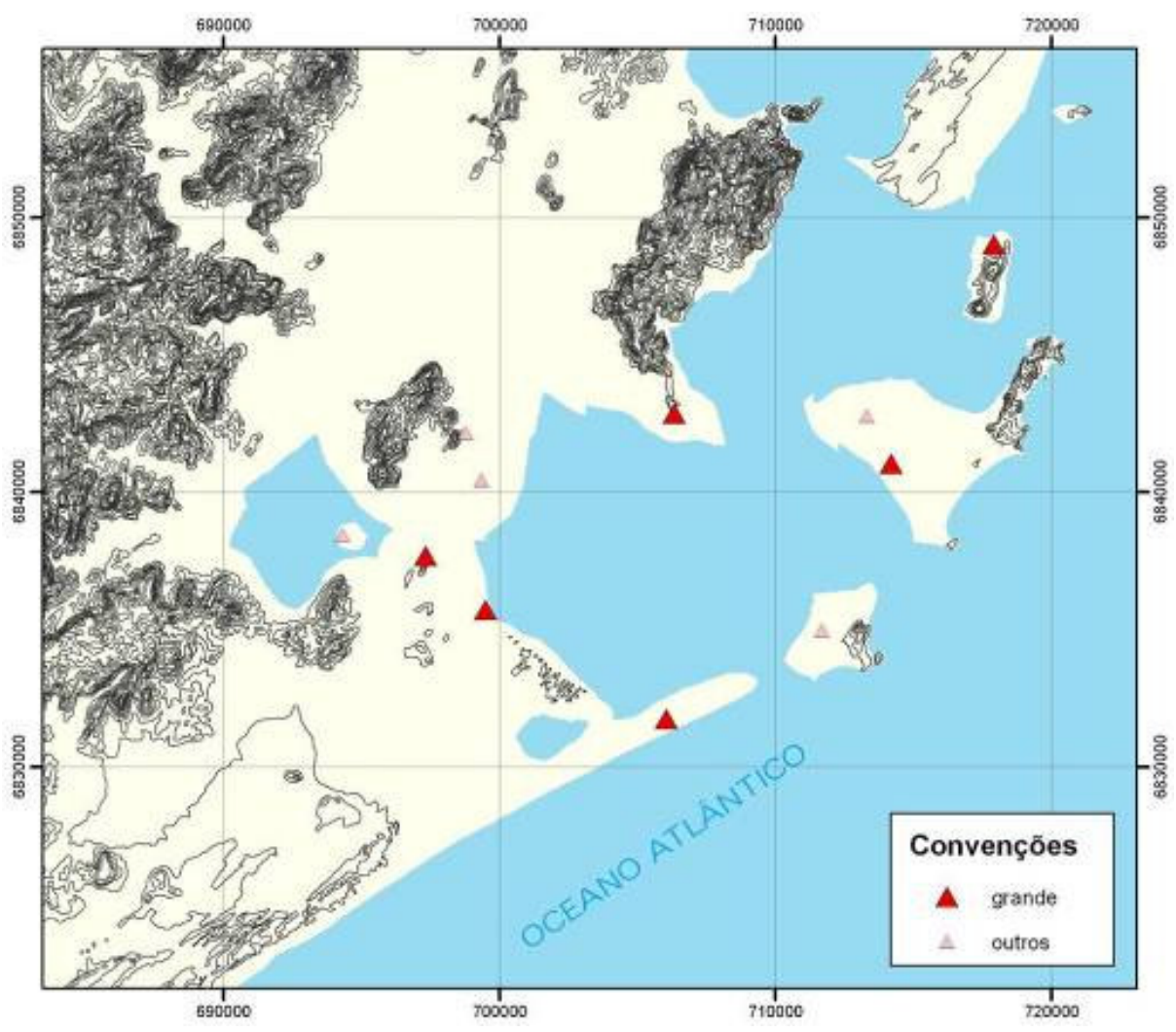

Fig 12. 3000 anos AP

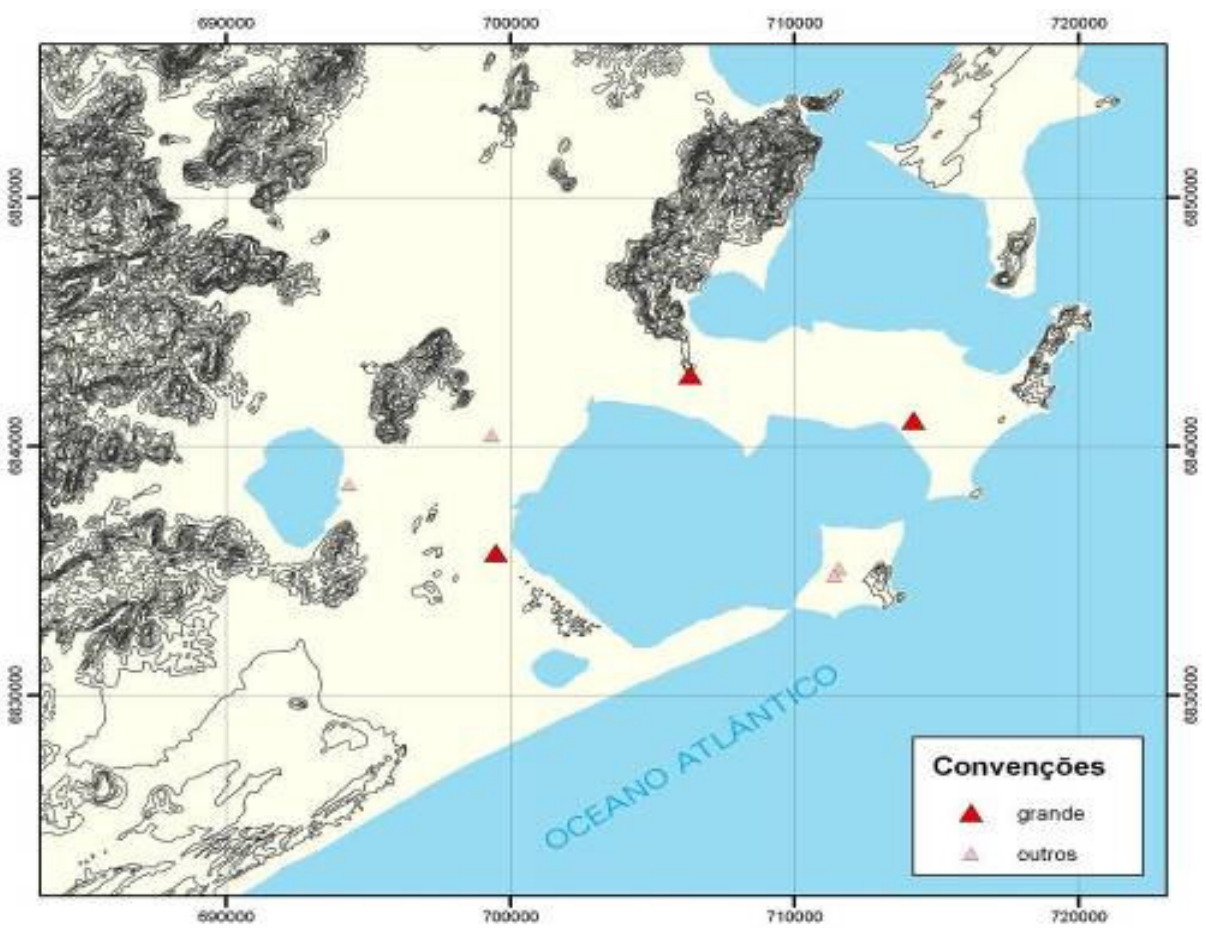

Fig 13. 1500 anos AP 


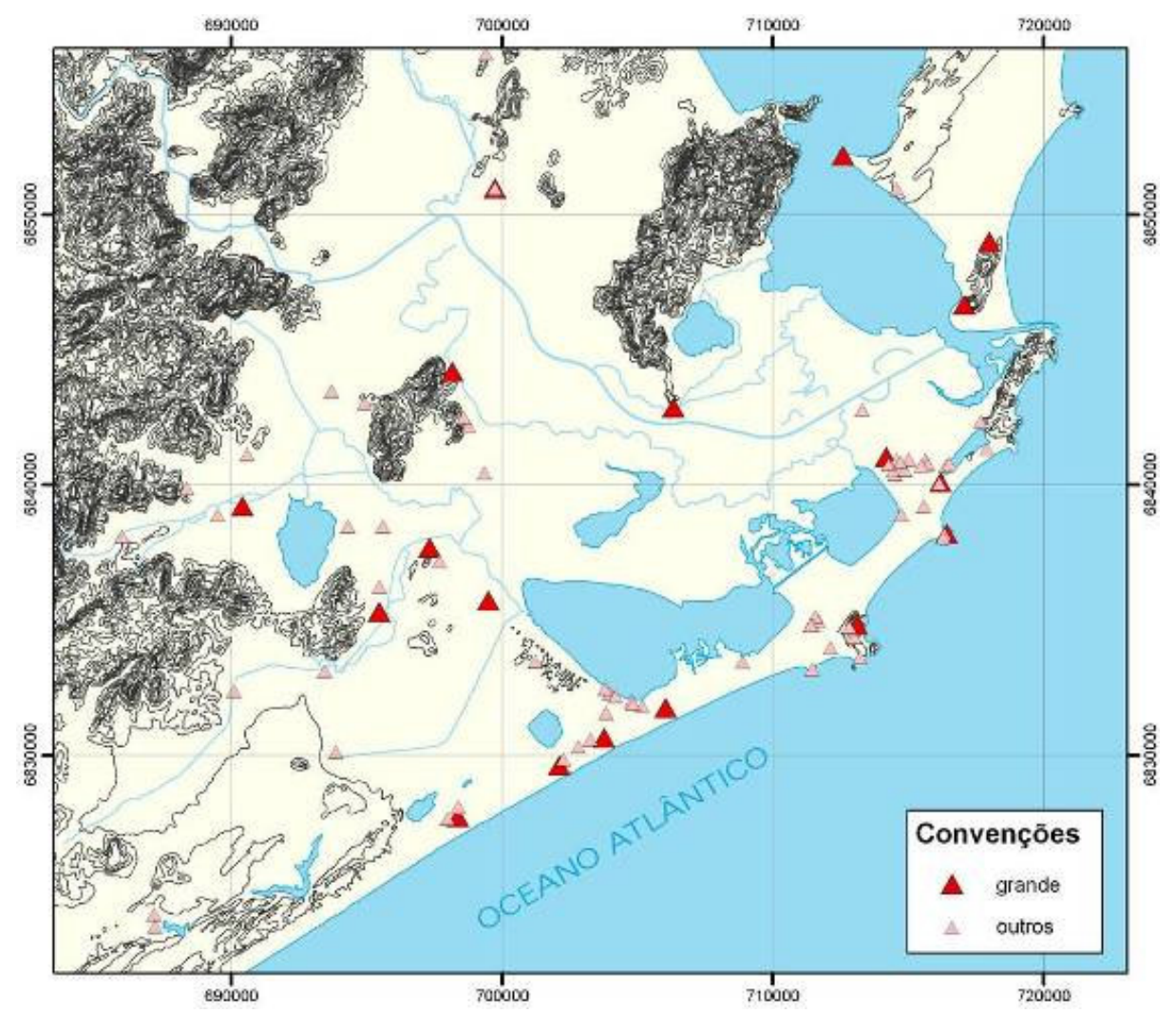

Fig 14. Atual

Estes mapas acima colocados contém alguns dos grandes e pequenos sambaquis que foram sendo erigidos conforme a lagoa foi recuando.

Isso demonstra a importância das atividades econômicas e simbólicas (pesqueiras e de coleta de material construtivo para a elevação dos sítios) baseadas nos recursos provenientes da lagoa e seus arredores.

Nas imagens acima (Figs. 9 a 14), notamos de que maneira a dinâmica geomorfológica da região afetou a paisagem. Em um primeiro momento, a região se caracterizava como uma baía, e alguns sambaquis em atividade na época estavam dispostos a beira da água, tanto nas beiradas da serra como em ilhas que mais tarde viriam a fazer parte do continente. Conforme o recuo do mar e a conseqüente formação de estuários e lagoas, outros sítios foram sendo elevados seguindo a disposição verificada nos mapas, ou seja, sua construção acompanhava o recuo do mar e os recursos estariam sempre ao alcance próximo das populações que ali se instalavam. Tanto os recursos marinhos e lagunares como os recursos provenientes das formações graníticas na região. 
É necessário compreendermos que, apesar de estes grupos provavelmente possuírem embarcações e de que o território de captação seja difícil de ser calculado, dado que, em se tratando de sociedades costeiras as distancias são mais facilmente percorridas devido a utilização deste tipo de transporte, poucos são os vestígios arqueofaunísticos encontrados nos sítios que demonstrem que seu território estaria além das áreas imediatas destes e consequentemente das formações lagunares. Ou seja, eles teriam deixado de consumir alimentos provenientes da mata atlântica em detrimento de um consumo voltado para recursos aquáticos e da vegetação de restinga que estaria mais próxima. Por sinal, nem mesmo nos sambaquis mais antigos que localizam-se nas encostas da serra, encontramos vestígios que pudessem aferir uma dieta voltada para os recursos da mata. Dessa maneira, cremos que tanto o material construtivo dos sítios quanto a economia sambaquieira está, e sempre esteve voltada para o mar, baías, estuários e lagoas.

O conteúdo malacológico presente nos sambaquis revela como a variação do nível do mar afeta o ambiente em termos de manutenção, distribuição e abundância das espécies que dependem de certo grau de salinidade para se desenvolverem.

O estudo do ambiente unido ao contexto arqueológico tem por objetivo a compreensão dos processos através dos quais uma sociedade se adapta culturalmente ao seu ambiente, e de como essas sociedades, para serem entendidas devem ser analisadas como adaptações a ambientes específicos. Para Steward, os padrões de comportamento cultural permitem a adaptação do homem ao ambiente mediante uma série de interações dinâmicas. Esta adaptação se realiza mediante ajustes comportamentais e variam de acordo com o sucesso alcançado pelas populações. O ser humano possui a capacidade de lidar com o ambiente por conta do acervo cultural, transmitido de uma geração a outra através da observação, da prática e da experiência (conhecimento empírico).

A cultura seria um instrumento de ajuste, um sistema de adaptação gerado por sociedades sob condições ambientais, espaciais, temporais e históricas particulares. A relação entre cultura e adaptação proporciona a sociedade elementos básicos para identificar e manejar os recursos disponíveis no ambiente. Esta permite a sobrevivência das populações estabelecendo estratégias de adaptação que variam ao longo do tempo.

O ambiente aparece para traçar oportunidades ou limitações ao desenvolvimento cultural do homem. Diferentes manipulações do ambiente criam vários tipos de configuração e sistemas culturais. Os componentes físicos e biológicos do meio podem ser utilizados de distintas maneiras por diversas populações que ocupam um mesmo ambiente. $\mathrm{O}$ processo de 
adaptação não se baseia somente na organização sociocultural, econômica e ambiental. Alguns dos fatores que podem explicar os diferentes modos de viver em um mesmo ambiente podem ser explicados principalmente pela ideologia de cada sociedade. Cada grupo social responde aos efeitos do ambiente de diferentes maneiras.

Por esse motivo, a nosso ver, o ambiente não determina necessariamente uma única maneira de utilizar e explorar os recursos que a paisagem lhe confere, mas abre um leque de possibilidades que cabe a cada uma das sociedades decidirem qual será a sua. No caso das sociedades sambaquieiras, sabemos que ocuparam por milhares de anos ambientes litorâneos, próximo aos grandes corpos d'água, e estavam totalmente adaptadas a esse modo de vida que influiu diretamente em sua cultura.

A nosso ver, existe uma relação definitiva entre a cultura desenvolvida pelo homem e o clima de uma zona particular. Por exemplo, o tipo de flora e fauna disponíveis no local de implantação de um sítio é importante para a seleção do habitat humano. É de se esperar que as populações que ocuparam o litoral sul de Santa Catarina não sejam exceção.

A maioria dos sítios pré-históricos litorâneos se encontra em áreas protegidas ou por morros ou pela vegetação, que diminui o impacto dos ventos vindos diretamente do oceano (Hurt, 1974). No entanto, diversos sambaquis se encontram em áreas abertas, aonde o vento sul e nordeste aparecem com grande força em determinadas épocas do ano. Apesar de esses sítios estarem muito expostos a ação dos ventos, eles se localizam em áreas aonde a produtividade para a captação de recursos é alta, normalmente a beira das lagoas aonde a pesca e a coleta de moluscos é abundante.

Segundo Hurt (1974), a seleção dos locais de implantação dos sítios, sejam eles de habitação ou de qualquer outra função pelos habitantes pescadores-coletores da costa sul catarinense se deveu a dois fatores principais: a disponibilidade de recursos e a capacidade de drenagem do sítio.

Dado que a pesca é a base principal da dieta dos povos sambaquieiros, e a coleta de moluscos é a base para a edificação das estruturas sambaquieiras, os sítios estão estrategicamente localizados em áreas aonde ambos os recursos aparecem em abundância. As baías, estuários e lagoas da região proporcionam os recursos para estas populações, e foram mais explorados do que as áreas de mar aberto, que por sua vez apresentam águas mais frias e espécies de coleta mais difíceis e que aparecem mais escassos no registro arqueológico. Os sítios costumam aparecer, portanto, em áreas mais próximas a caminhos d'agua interiores com mais freqüência que em áreas mais próximas ao mar (Hurt, 1974). 
Para os fins deste trabalho acreditamos ser necessária a descrição do entorno dos sítios, ou seja, da paisagem em que se inserem, ou que se inseriam na época de construção dos sambaquis para podermos verificar o modo pelos quais os sambaquieiros se apropriaram dos recursos disponíveis na época em que os sítios foram erigidos.

Do ponto de vista ecológico, a paisagem é o meio em pelo qual os grupos pré históricos encontram sua sobrevivência, uma vez que esta se dá através da captação de recursos que o ambiente disponibiliza. Recursos estes que devem estar presentes no registro arqueológico, tanto na função de refugo alimentar, como de elementos de manufatura de artefatos.

Gaspar apud Klokler (2001) diz que a estrutura do conceito de captação está ligada a uma tendência de minimizar os esforços para a obtenção de alimentos e matérias primas para a confecção de artefatos através do local de implantação do sítio, ou seja, o sítio deve se localizar próximo às fontes. A localização dos sítios desempenharia um papel predominante no que se refere as decisões relacionadas a manutenção do grupo.

No caso das sociedades sambaquieiras, notamos através do registro deixados por eles, e através da localização dos sítios em relação à paleolaguna que a área de exploração dos recursos alimentícios e de material para a construção dos sambaquis estava na lagoa e áreas adjacentes. As espécies encontradas nas camadas dos sambaquis são de fácil captura, tanto no que se refere aos peixes quanto aos moluscos. A facilidade de coleta, abundância e previsibilidade fazem com que os moluscos e peixes representem um recurso especial para essas populações.

Já foi dito antes o quão produtivo é o ambiente estuarino, dado que a concentração de nutrientes causada pelo encontro de água doce e salgada, aliada a alta pluviosidade da região o torna um local privilegiado para o desenvolvimento de espécies aquáticas.

A mudança de material construtivo dos sítios pode estar relacionada com as mudanças ambientais ocorridas na região. Ela poderia ser uma resposta cultural dos sambaquieiros em relação às pressões ambientais aos quais estavam sujeitos, tais como a variação do nível do mar e a evolução geomorfológica da planície costeira.

A possibilidade de superexploração ligada a um aumento demográfico também é viável, dado que como já foi dito antes, a sociedade sambaquieira estava instalada em uma área de alta produtividade de recursos, o que desencorajaria a mobilidade, fazendo com que essas populações se tornassem sedentárias, e provocaria um aumento populacional. É certo que o número de sambaquis funerários e consequentemente o de sambaquieiros sepultados 
cresceu vertiginosamente por volta dos 4000 anos AP. Ou seja, ocorreu de fato um aumento populacional na região, que, de alguma maneira pode ter interferido no ambiente.

\subsection{Distribuição dos sítios e cronologia}

A área de pesquisa concentra um grande número de sambaquis, com datas que variam de 7500 anos AP até 1000 anos AP aproximadamente. Trata-se de uma região que evoluiu geomorfologicamente de maneira que a construção de sambaquis foi direcionada para a constante presença dos corpos d'agua provedores de alimentos.

Em um primeiro momento, a morfologia, composição e localização dos sítios se apresenta diferente dos clássicos sambaquis da região, conhecidos pelas suas grandes dimensões.

O projeto temático no qual esta pesquisa está inserida tem como um dos seus pontos principais compreender cronologicamente a ocupação da área pelos povos construtores de sambaquis. Sendo assim, inúmeras datações foram realizadas pela equipe do projeto, o que resultou em um grande quadro cronológico que pode enfim elucidar um pouco desta questão.

Os sambaquis mais antigos estão situados em áreas mais próximas as encostas da serra, e ainda sim estão ligados diretamente com o modo de viver de populações litorâneas sambaquieiras conhecidas em todo o litoral brasileiro. Em um primeiro momento, estes povos teriam ocupado a região e nela encontraram um local propício para o desenvolvimento de sua cultura. Conforme o aumento demográfico foi ocorrendo, novas áreas foram sendo ocupadas, áreas estas que seguiriam o deslocamento dos corpos d'água e que, por fim atingiriam a parte mais ao leste da região. Sambaquis antigos também são vistos na beira da praia, dado que o processo geomorfológico ocorrido propiciou a formação de uma barreira arenosa que dividiu a formação lagunar do mar aberto já por volta de 4200 AP.

O primeiro passo para compreender os diferentes momentos de ocupação no litoral de Santa Catarina foi entender os contextos ambientais relativos a formação do litoral na região (VNM), para depois correlacioná-los com a cronologia obtida através das datações realizadas pelo projeto, e assim construir um quadro espaço-temporal para a ocupação sambaquieira na área. 


\subsection{Espaço x Tempo}

Durante esta evolução cronológica, é possível notar que a morfologia, dimensão e composição dos sítios se alteraram. Eles, em determinado momento - por volta de 4500 anos AP - se tornaram gigantescas obras monumentais de culto aos ancestrais, - muito provavelmente marcadores territoriais (Gaspar 1991), e deixaram de ser construídos com o material que compunha os sítios mais antigos. Mais tarde, os sítios então em atividade, começaram a apresentar outras mudanças relativas ao material construtivo. Alguns sambaquis apresentaram, em sua porção superior camadas de Terra Preta utilizadas para a elevação do monumento, com pouquíssimas conchas.

Temos então três diferentes períodos de ocupação na região pela sociedade sambaquieira. Estes períodos serão aqui denominados como o período Pré-Clássico num primeiro momento (7500 AP a $4500 \mathrm{AP}$ ), e em um segundo momento - quando ocorre a expansão demográfica e territorial- como o período Clássico (4500 AP a 1500 AP). O terceiro e último, aqui chamado de período Tardio (a partir de 1500 anos AP) se refere ao final da ocupação sambaquieira, quando em alguns sítios as conchas são substituídas pela Terra Preta e aparecem sítios com elementos de outras culturas como as culturas Jê por exemplo (Farias \& DeBlasis, 2006) misturadas a elementos culturais sambaquieiros. O período Tardio ainda apresenta sambaquis tradicionais, construídos de conchas, com sepultamentos e artefatos associados, mas para fins didáticos os períodos são aqui divididos pela razão cronológica.

Num primeiro momento, fica claro que há uma tendência de construir sambaquis em áreas mais próximas às encostas da serra, interpretadas como resultado da transgressão marinha que ocorreu no Holoceno. Como já apontou Kneip (2004), seguiu-se um segundo momento de ocupação relativo à regressão marítima, com os sambaquis localizados em áreas mais baixas e mais próximas a linha de costa atual.

O ponto aqui colocado remete à ocupação do litoral brasileiro pelos sambaquieiros. Hurt (1983) e Calippo (2004), já haviam levantado esta questão em trabalhos anteriores.

Calippo propõe duas rotas de ocupação dos grupos sambaquieiros em Cananéia, litoral sul do estado de São Paulo. A primeira seria que eles tivessem vindo do planalto através do Vale do Ribeira, já que são encontrados ao longo do Vale diversos sambaquis fluviais. A outra proposta é que eles tivessem ocupado a região através de um litoral que estaria hoje submerso. Hurt acredita na possibilidade de os grupos do interior terem atingido o litoral já adaptados a uma exploração de recursos naturais da praia. Esta pré adaptação estaria 
marcada pela coleta de moluscos por diversas tradições tecnológicas que ocorrem nos abrigos, e pela ocorrência de anzóis na fase Serranópolis (Schimitz, 1980).

Por mais diferentes em termos de tamanho e composição que os sambaquis da região se apresentem (considerando a variação cronológica), a função da maioria dos sítios e seu modo de construção perdurou por milênios. Temos portanto uma mesma cultura ocupando a área por aproximadamente 6000 anos. Em relação à formação e construção dos sítios, temos a elevação de pequenos mounds que, conforme o tempo foram sendo construídos um ao lado do outro até se unirem em uma grande plataforma que apresentaria uma dimensão elevada (Bendazolli, 2007).

A função da maioria dos sítios da área é bem conhecida: tratam-se de sítios exclusivamente funerários, sem evidências de moradia nos próprios sambaquis - como ocorre em sambaquis do Rio de Janeiro (Barbosa et al 1994). São exceções pequenos sambaquis encontrados nas últimas campanhas do projeto que aparentemente apresentam apenas uma ou duas camadas de conchas, normalmente sobre pacotes arenosos, cuja função ainda não foi esclarecida. Peixoto (2008) sugere que estas áreas poderiam ser referentes ao acúmulo de conchas para posterior transporte para os grandes sítios, no entanto ela não esclarece o porquê da estratigrafia destes sítios se apresentarem definidas.

O que vale é compreender que a ocupação desta região se deu de maneira tão bem sucedida por tantos milênios, com um mesmo modo de vida e de culto aos mortos que o que diferencia os períodos Pré-Clássico e Clássico, é basicamente a composição malacológica do material construtivo dos sítios e as dimensões dos sambaquis. O ambiente e a economia, apesar da dinâmica da paisagem, não deve ter alterado significantemente na vida dos povos sambaquieiros da região sul do litoral catarinense. O material faunístico encontrado nos sítios pesquisados permaneceu basicamente o mesmo, com exceção da matriz construtiva dos sítios, e a industria lítica aparentemente também permaneceu a mesma.

Em relação a industria lítica é preciso esclarecer que não foi feita nenhuma análise em laboratório, apenas registradas as impressões de campo com o material encontrado em superfície no sítio. Segundo Belém (2007), a indústria sambaquieira se caracteriza por ser uma industria polida, que utiliza como suporte principalmente seixos, sendo que a matéria prima preferencial é a Rocha Básica. Lascamentos ocorrem também, porém, dado que o material utilizado pela pesquisadora se baseia principalmente em material do sítio Jaboticabeira II, que é um sítio funerário, a maioria dos artefatos já se encontram prontos, consequentemente encontrar vestígios de preparação destes é raro, pois os artefatos são 
carregados já terminados para o sítio. São também, na maioria das vezes artefatos multifuncionais, que recebem retoques conforme o grau de utilização.

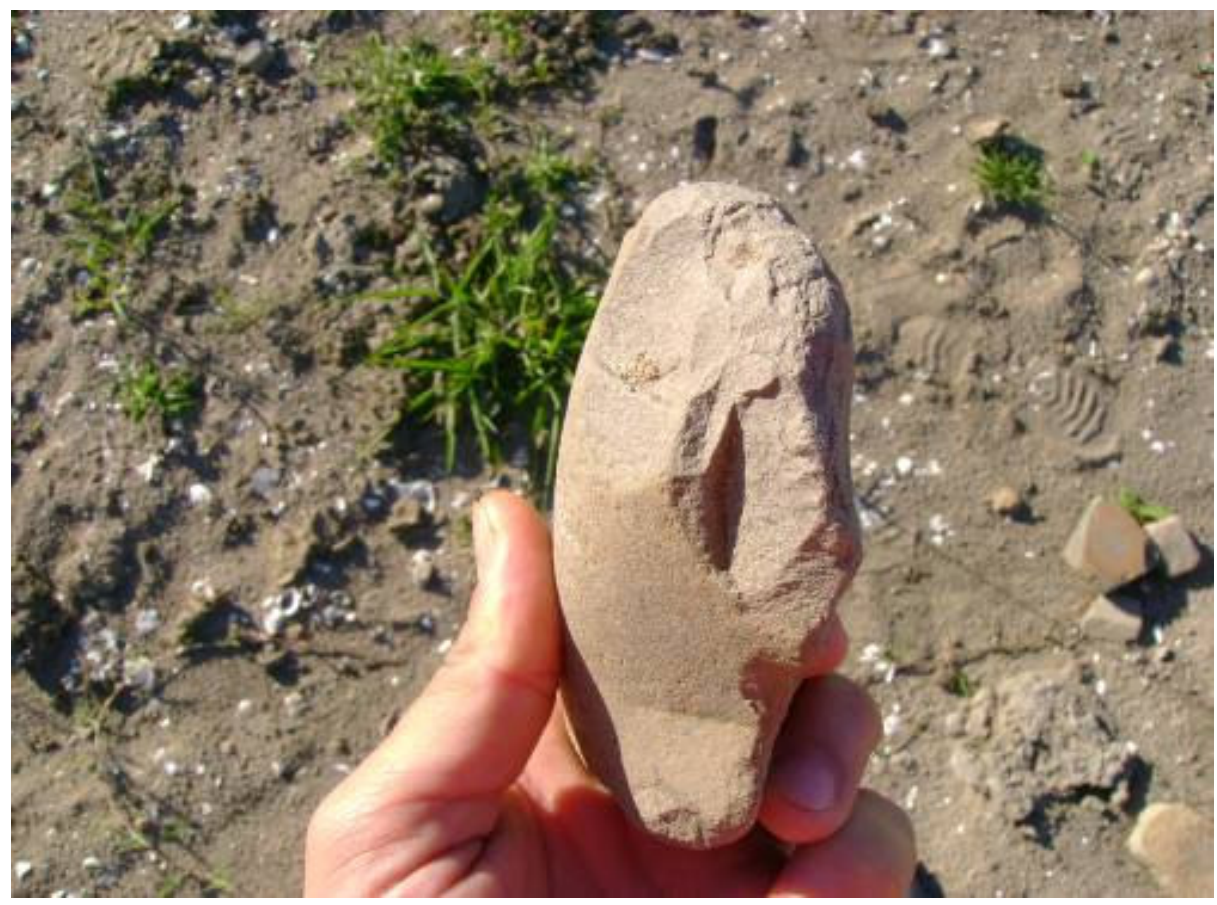

Fig 15 - Material lítico encontrado no sítio Lageado

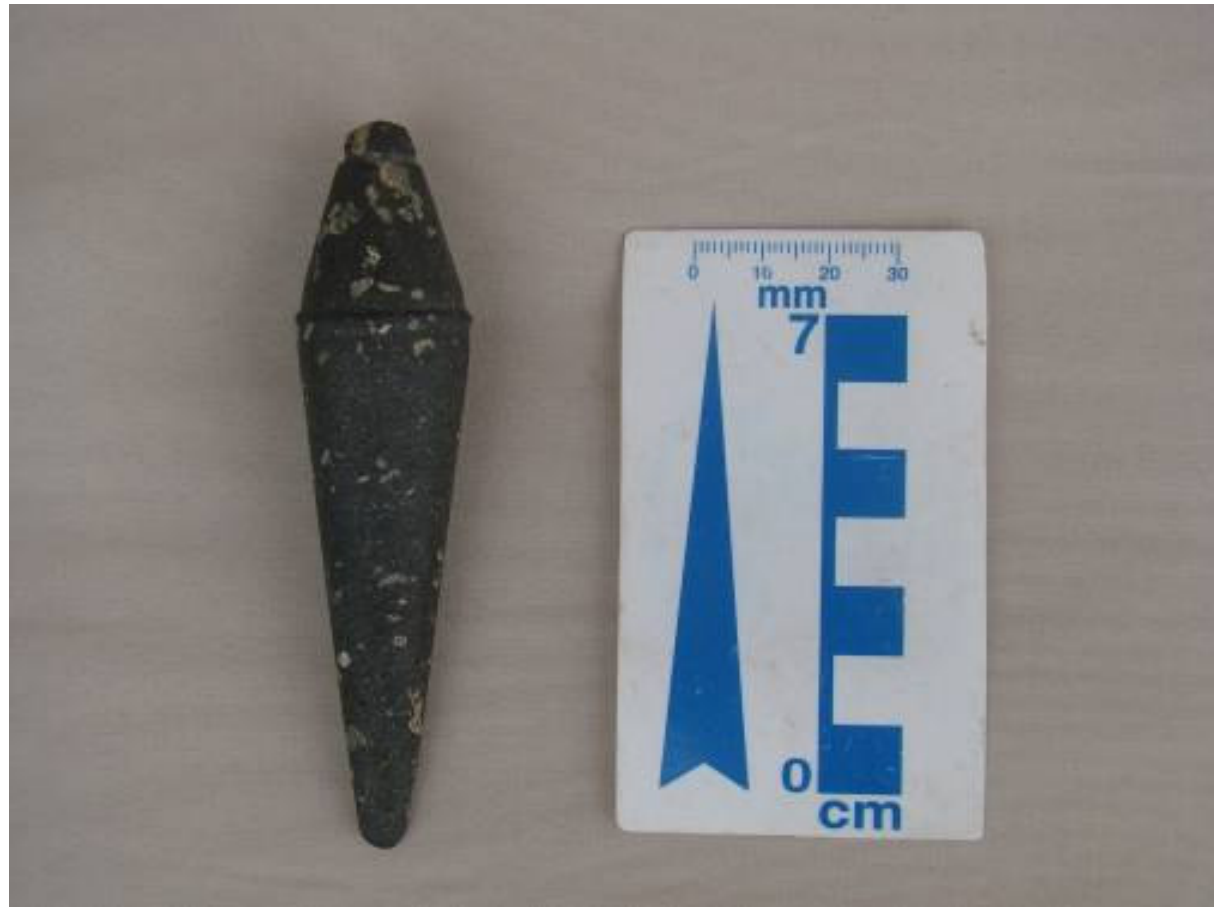

Fig 16 - Fuso encontrado no sítio Lageado 
Essa Indústria, apesar de parecer um tanto rudimentar, como já foi classificada anteriormente (Beck, 1972), não deve ser assim considerada. Zoólitos foram encontrados em diversos sambaquis, e se tratam de artefatos elaborados com o máximo de cuidado e rigor estético. Em um dos sítios trabalhados nesta pesquisa inclusive, o sambaqui Lageado, foi encontrado um zoólito em forma de pássaro.

Ou seja, desde o início da ocupação sambaquieira na região (o sítio Lageado é um dos sambaquis mais antigos, apresentando uma data de 5980 anos cal AP) estes artefatos minuciosamente trabalhados já estavam em circulação. Prous (1992) crê que seriam necessárias muitas horas dispendidas para se realizar uma escultura deste tipo, o que talvez pudesse nos remeter a uma especialização do trabalho nessas sociedades desde a entrada destas populações no litoral sul de Santa Catarina.

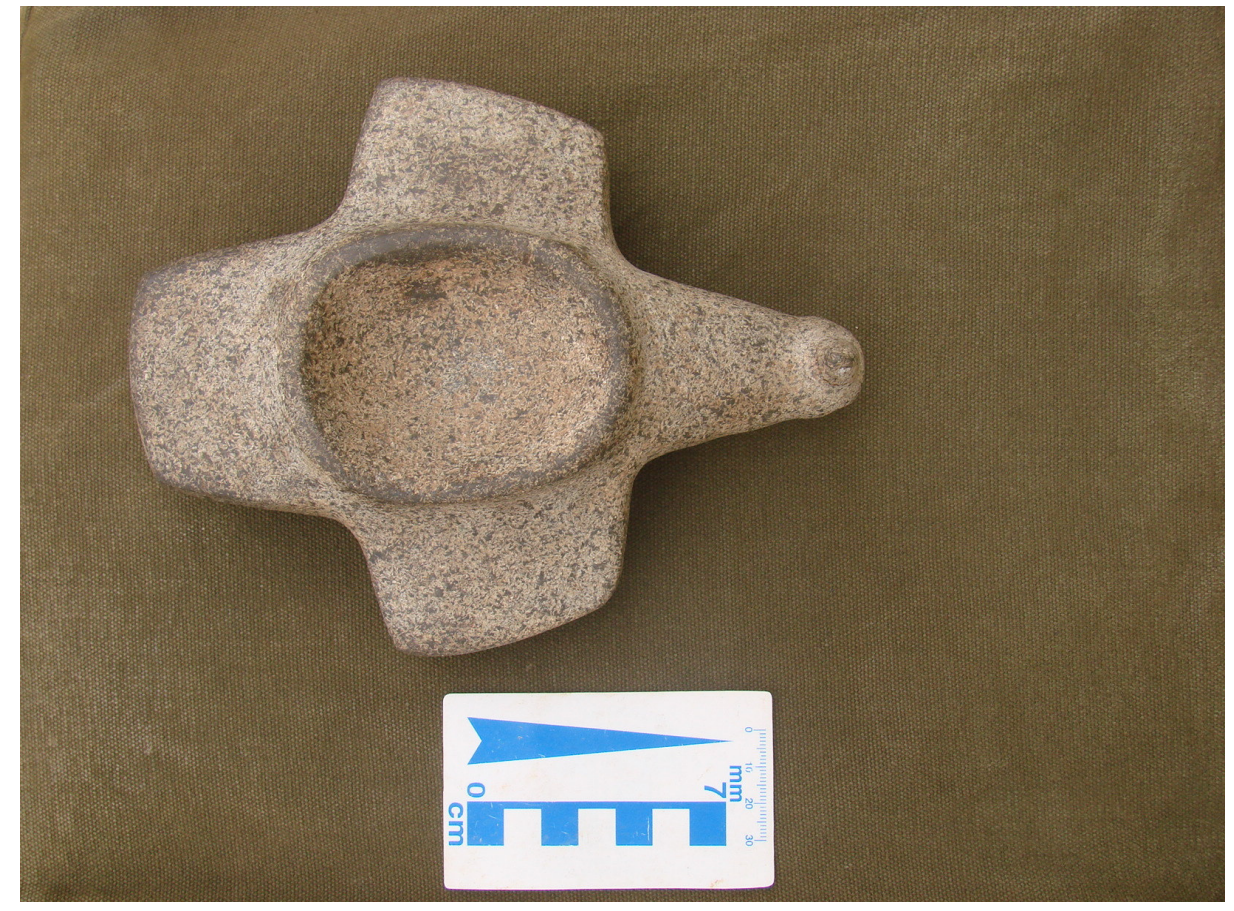

Fig. 17. Zoólito encontrado no sítio Lageado

O litoral meridional de Santa Catarina teria sido um local de fixação dos povos construtores de sambaquis devido a diversos motivos: o primeiro seria a paisagem, no sentido geográfico, na qual a formação de lagoas e estuários poderiam prover a essa população uma dieta muito rica, além disso, a formação de ambientes lagunares, com águas mais quentes e menos salobras é favorável a proliferação de moluscos, material utilizado para a construção de seus monumentos. Esta dissertação parte do princípio de que os moluscos não teriam um 
papel relevante na dieta diária desses povos, mas serviriam como material de elevação de plataformas, sejam elas mortuárias ou apenas para a drenagem de determinados locais de uso sambaquieiro. Isso não exclui a possibilidade dos moluscos serem consumidos como parte da dieta, no entanto a base desta, como já foi comprovado por Plens (2007) e De Masi (2001) através de análises de isótopos estáveis de Carbono e Nitrogênio não estava relacionada diretamente com o consumo de moluscos, mas sim de peixes e no caso dos sambaquis fluviais, de mamíferos.

Conforme a população cresce, ela tende a se expandir e demarcar sua presença através da elevação de sambaquis cada vez maiores. É nesse estágio que a denominação Clássico se torna mais clara. Ocorre uma explosão demográfica e os grupos passam a compartilhar o território, porém divididos em grupos menores, cada um demarcando sua presença, sem que isso afete as relações pacíficas entre esses grupos. Eles partilhariam a lagoa e seus recursos, a mata e seus recursos, e no entanto cada grupo deveria ter seu local de culto aos mortos e do qual eles mesmos deveriam fazer parte em algum momento.

Esta seria uma tradição que viria desde os princípios da ocupação sambaquieira, dado que os sítios mais antigos apesar de menores, podem ser considerados monumentos funerários. A diferença mais marcante entre os períodos seria a alta demográfica que viria a acontecer mil e quinhentos anos mais tarde. 


\section{Capítulo IV - Material e Métodos}

Apesar de seu grande potencial, a análise da fauna presente nos sítios era antigamente incorporada nos relatórios apenas como uma simples listagem das espécies que apareciam no registro, sem que interpretações de ordem social e cultural fossem realizadas. No entanto, a partir dos anos 60, as pesquisas arqueológicas direcionaram o foco das suas investigações para os sistemas adaptativos e abordagens ecológicas relacionando os processos culturais a possíveis mudanças ambientais (Andrade Lima, 1991).

A fauna que integra o registro arqueológico de um sítio é normalmente associada a escolhas culturais pré-determinadas pelas populações pretéritas, ou seja, resultantes do comportamento humano.

A Zooarqueologia desenvolve-se então como uma subdisciplina da arqueologia, focando seus estudos nos vestígios faunísticos encontrados em sítios arqueológicos. Ela reflete a perspectiva antropológica do estudo de vestígios faunísticos provenientes de sítios arqueológicos, com o objetivo de obter informações sobre o comportamento humano pretérito e as condições paleoambientais (Reitz \& Wing, 1999). Através do resgate e análise de restos de animais vertebrados e invertebrados, a disciplina procura, além de contribuir no entendimento de possíveis mudanças climáticas e ambientais, compreender antigos padrões de comportamento, subsistência e adaptação cultural. Dessa maneira ela apresenta uma abordagem mais cultural do que propriamente zoológica.

Para o desenvolvimento deste trabalho foi utilizada uma metodologia de coleta e amostragem específica para o trabalho e análise zooarqueológica. Poucos estudos de caráter zooarqueológico feitos anteriormente (Klokler, 2001; Barbosa 2007) tiveram a preocupação em realizar uma amostragem que fosse sistemática, não-seletiva e parcimoniosa. Dessa maneira, adotamos o padrão de amostragem já utilizado com sucesso no sítio Jabuticabeira II, o qual permite comparações intersítios, tentando assim evitar desvios de coleta e reduzindo a redundância nos resultados.

Muitos pesquisadores, ao realizar coletas de material faunístico em campo, sem um critério específico para o estudo zooarqueológico, optavam por coletas seletivas, prejudicando dessa maneira a interpretação dos resultados obtidos após a análise laboratorial. O presente estudo utiliza uma coleta sistemática do material faunístico de modo que nenhum conhecimento se perca no transporte entre o campo e o laboratório. 
Devido a grande importância que a estratégia de amostragem exerce em estudos zooarqueológicos, optamos por realizar a análise das camadas dos sambaquis em questão baseadas no protocolo de amostragem desenvolvido por Sheel-Ybert et al. (2005/2006) para coletas antracológicas e zooarqueológicas. Dessa maneira pudemos tratar a análise faunística como análise de sedimento, evitando assim qualquer tipo de intervenção do coletor em campo.

A intenção ao optarmos por este tipo de coleta é evidenciar a ocorrência de variação significativa entre as camadas.

\subsection{Amostragem por colunas}

A amostragem por colunas foi a estratégia de coleta selecionada por consideramos a mais eficiente para o estudo da matriz sedimentar do sítio, uma vez que possibilita a identificação de variações dos componentes das camadas do sambaqui.

Apesar da aparente constância dos elementos, constatamos que a variabilidade interna dos componentes dos sambaquis é alta, no entanto como veremos mais tarde, as principais espécies que constituem a matriz dos sítios se mantém as mesmas, diferenciando-se apenas de sítio pra sítio.

As amostras foram realizadas da seguinte maneira:

No sambaqui Jabuticabeira I, usufruímos da experiência prévia das análises no sambaqui Jabuticabeira II (Klokler, 2001; Barbosa 2007) e utilizamos os cortes presentes no sítio, feitos pela mineração-extração de conchas ocorrida no século XX. Portanto, conforme o procedimento adotado anteriormente algumas áreas dos cortes foram escolhidas, limpas e retificadas, e minuciosamente mapeados, desenhados, fotografados e descritos.

Uma vez estabelecida a sequiência estratigráfica de cada perfil a ser analisado, foram coletadas amostras de $15 \times 15 \times 15 \mathrm{~cm}$ de cada camada descrita e considerada relevante. Desta maneira poderíamos obter uma análise detalhada acerca da matriz sedimentar do sambaqui.

Cada amostra foi pesada e colocada em sacos plásticos etiquetados e referenciados em relação a camada do perfil. Deste modo pudemos obter informações que iam da base dos sambaquis ao topo atual.

Para os outros sítios estudados, Caipora e Lageado foi necessária a abertura de cortes para evidenciar os perfis, pois estes dois sambaquis não parecem ter sofrido uma superexploração como o Jaboticabeira I, o que não significa que eles estavam intactos, mas 
melhor preservados que o primeiro. Após a abertura dos perfis a metodologia aplicada foi a mesma, de registro e amostragem.

Para a realização desta pesquisa, este tipo de coleta é a ideal, no entanto o tamanho da amostra $(15 \times 15 \times 15 \mathrm{~cm})$ acabou se mostrando muito grande, pois nos forneceu muito material, e o trabalho acabou por se tornar muito dispendioso, acarretando em anos de laboratório para a realização apenas da triagem. Em compensação, não corremos risco algum de perdermos elementos raros. As amostras têm tamanho mais do que suficiente para refletir a distribuição das espécies presentes no depósito onde a coleta foi realizada, e a observação cuidadosa dos perfis nos permitiu evidenciar as estruturas presentes.

\subsection{Metodologia de análise em laboratório}

Em relação às análises laboratoriais, optamos por utilizar o método de pesagem para a verificação das proporções entre as espécies presentes em cada camada dos sambaquis. Este método desenvolvido pela "California School of Midden Analysis", nos Estados Unidos, destaca-se por utilizar o peso dos fragmentos de conchas para determinar as porcentagens relativas de abundância dos moluscos.

A crítica ao emprego desse método está relacionada aos aspectos pós deposicionais, já que durante o processo de decomposição das valvas, estas perderiam massa e essa perda estaria refletida nos resultados obtidos em laboratório.

Alguns autores argumentam que o método de pesagem não é tão confiável comparado ao NMI (Número Mínimo de Indivíduos), pois os dados baseados no peso são afetados em diferentes graus por diversas variáveis tais como grau de preservação do sítio, tamanho individual do molusco, idade, tamanho da malha da peneira, diferenças entre peso individual entre espécies, grau de fragmentação e dissolução química (Klokler, 2001). É fato que conchas expostas as intempéries tendem a ter uma perda de peso em relação às camadas mais protegidas, no entanto "essas diferenças de peso são importantes mas não alteram muito a conservação das proporções das espécies dentro de uma amostra" (Hesse \& Prieur 1999, apud Klokler 2001).

Portanto a seguinte sequiência de procedimentos foi adotada em laboratório ( Klokler, 2001) :

Cada amostra seca foi pesada antes de qualquer outro procedimento. 
1) Lavagem da amostra em água corrente com peneiras de malhas de $4 \mathrm{~mm}$ e $2 \mathrm{~mm}$.

2) Após secarem (naturalmente, sem o auxilio de estufas elétricas para evitar maior fragmentação térmica) as amostras foram submetidas ao processo de triagem de seus componentes.

3) A pesagem de cada componente foi realizada em uma balança eletrônica de precisão, e os resultados devidamente registrados.

Optamos por utilizar as malhas de 4 e $2 \mathrm{~mm}$ por estar de acordo com as proposições propostas por outros autores (Waselkov, 1987) que julgam a malha de $2 \mathrm{~mm}$ a que permite melhores condições de reconhecimento e análise do material (Klokler, 2001). Além disso o uso de duas peneiras já permite verificar o grau de fragmentação das conchas em cada camada e agiliza o processo posterior de triagem.

Em relação aos ossos, efetuamos a contagem de cada elemento por camada arqueológica, especificando os componentes e as espécies a que estes se referem. Quando algum artefato era encontrado, recebia um tratamento diferenciado, sendo guardado em sacos bolha e devidamente registrado. Dessa maneira foi possível verificar as espécies e a freqüência com estas aparecem no registro arqueológico de cada sítio.

Após a triagem e a última pesagem, foi colhida uma subamostra de cada camada, composta por 50 valvas inteiras do mesmo lado de Anomalocardias colhidas aleatoriamente. Cada valva teve sua largura e comprimento medido. O objetivo desta analise foi de tentar verificar variações nas dimensões das populações de berbigões exploradas para a formação das camadas. As ostras tiveram suas valvas e as charneiras medidas.

\subsection{Os sítios estudados}

\subsubsection{Sambaqui Caipora}

O sambaqui Caipora foi encontrado em 2006 por meio de prospecções realizadas pela equipe do projeto para o levantamento de sítios na região que compreende os municípios da área do Projeto temático Sambaquis e Paisagem.

O interesse no sítio se deveu ao fato de sua composição faunística e sedimentar apresentar-se bastante diferente da composição do Jaboticabeira I, pelo fato de se encontrar mais próximo as encostas da serra, mas principalmente devido a sua data ter apresentado-se 
bastante recuada (7570 anos cal AP) para os padrões sambaquieiros conhecidos em Santa Catarina.

O sítio localiza-se no município de Treze de Maio, mais especificamente no bairro São Gabriel, em propriedade do Sr. Pedro Fraganini UTM: (22J 0685972/ 6838075). O acesso ao sítio é possível através da pequena estrada que segue ao dito município.

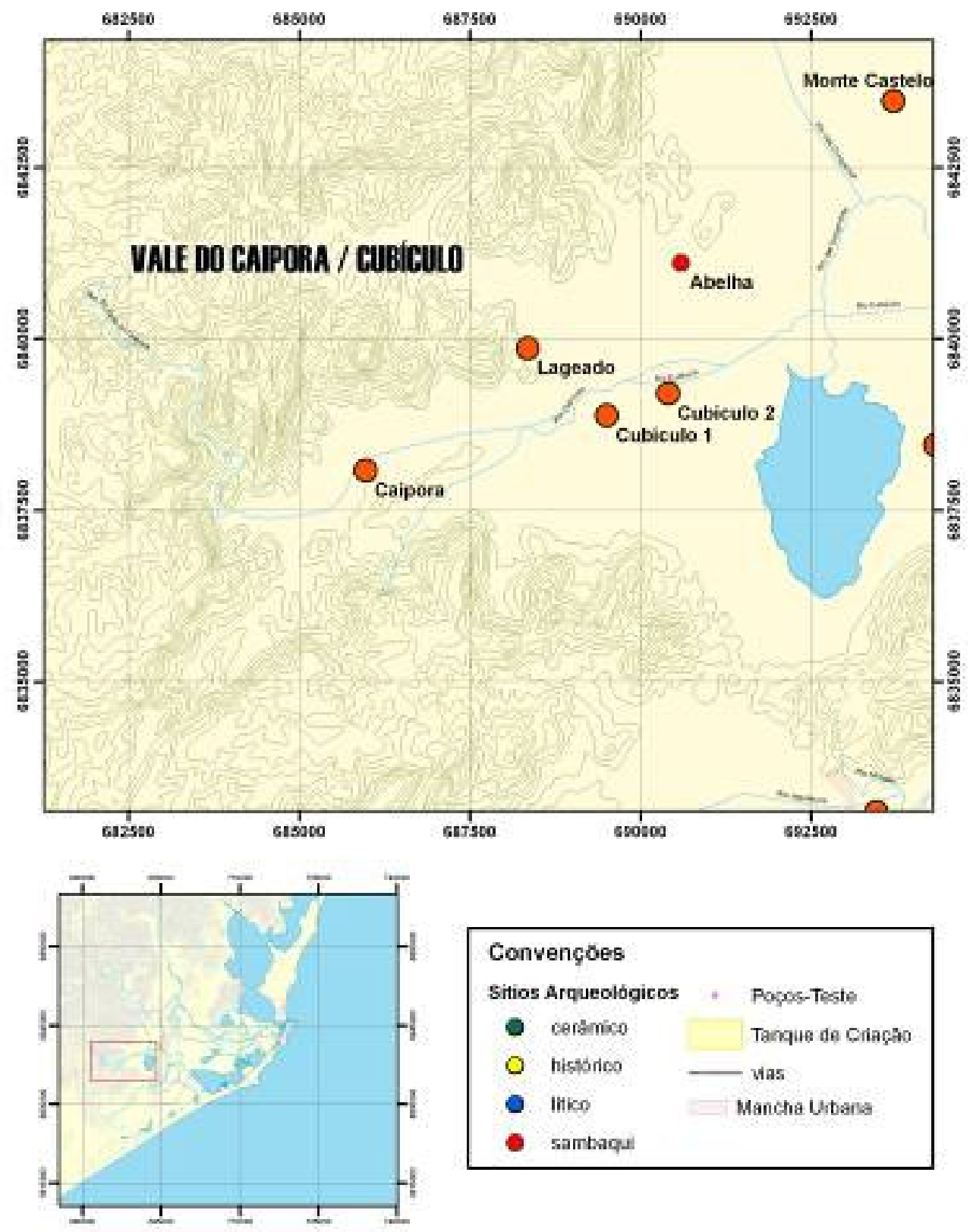

Fig. 18 - Localização dos sítios Caipora e Lageado 
Este pequeno sambaqui monticular de base arrendondada apresenta $25 \mathrm{~m}$ de comprimento e $20 \mathrm{~m}$ de largura, com aproximadamente $3 \mathrm{~m}$ de altura, e está assentado sobre um afloramento granítico que faz parte já do início dos patamares da Serra Geral. O sítio situa-se as margens do leito retificado do rio Caipora, ancorado em uma das encostas cristalinas do que seria um paleoístmo em meio a paleolagoa de Santa Marta no momento da máxima transgressão marinha. O terreno em torno é charcoso e hoje é utilizado como pasto pelo morador. No alto dos morros que circundam a área alagadiça em torno do sítio, a vegetação é composta por floresta ombrófila de alto porte, enquanto nas baixas encostas existe ocupação humana mais intensa e a área encontra-se desmatada.

Infelizmente o sítio encontra-se em um alto grau de deterioração, dado que a retirada de conchas do sambaqui para usos particulares causou um grande impacto na forma e no tamanho do sítio. Além disso, foi construído um forno para a fabricação de cal em sua porção norte, e uma pequena estrada de acesso ainda corta o sambaqui em sua porção central.

Moradores locais afirmam ter encontrado diversos artefatos líticos, além de sepultamentos no entorno do sambaqui.

Em campo:

Aproveitando os cortes recentes feitos pelos moradores para a colocação do forno e da estrada, pudemos retificar as paredes expostas, realizar os desenhos dos perfis e fazer as coletas necessárias de sedimento e zooarqueologia. No primeiro corte de $1 \mathrm{~m}$ x 1,8m que fica na porção Norte do sambaqui alcançamos a base do sítio e no segundo, localizado no topo atual, descemos ate $1 \mathrm{~m}$ de profundidade. 


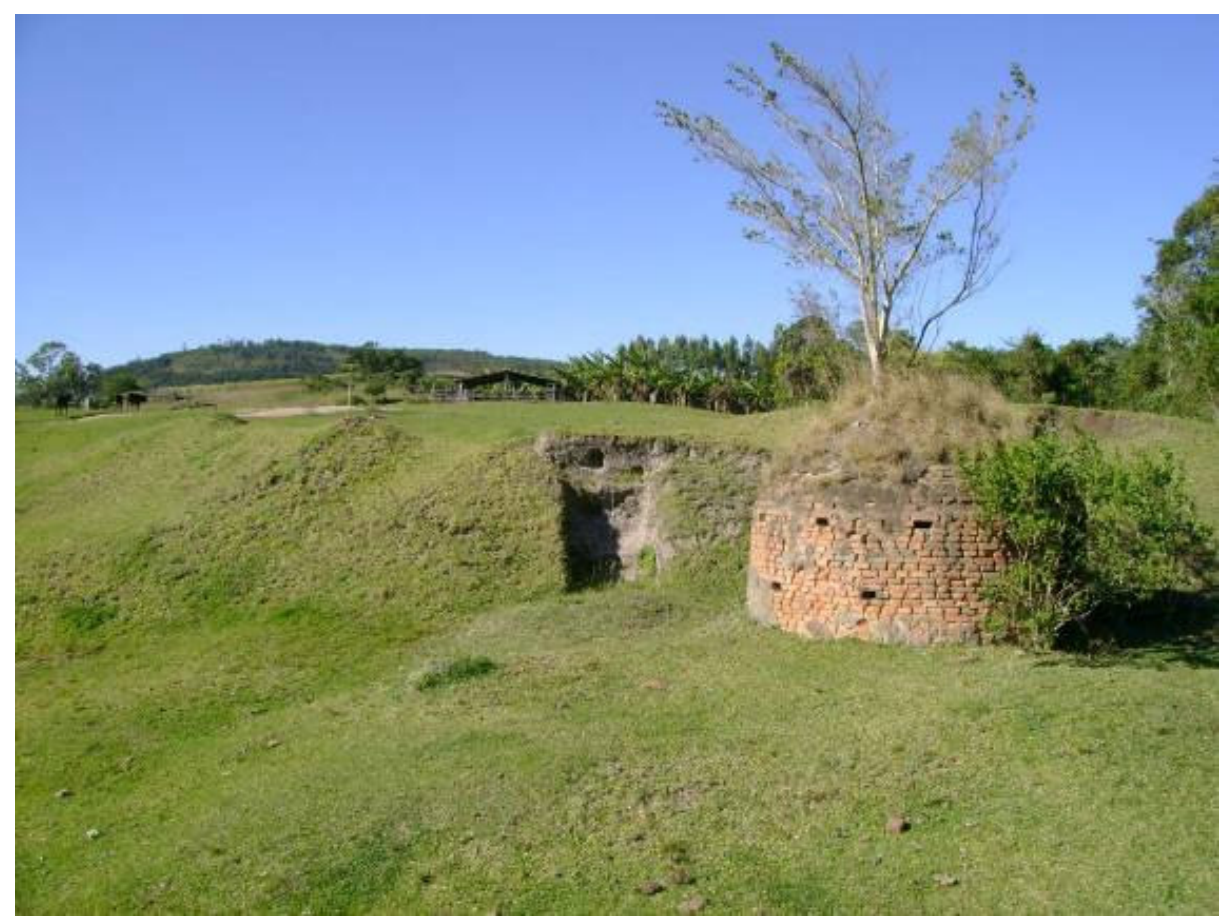

Fig. 19. Sambaqui Caipora - foto: Tania Ferraz

\section{Descrição das camadas estratigráficas do Sambaqui Caipora}

\section{Perfil Noroeste (topo do sambaqui) UTM (22J 0685969/683806)}

Camada 1: sedimento areno-argiloso, compactado, de coloração marrom acinzentada, com muitos fragmentos de rocha granítica em decomposição, sem a presença de conchas.

Camada 2: sedimento areno-argiloso, compactado, de coloração negra, com muitos fragmentos de rocha granítica em decomposição, sem a presença de conchas

Camada 3: sedimento areno-argiloso, de coloração acinzentada, com a presença de grande quantidade de conchas inteiras de ostra e berbigões.

Camada 4: sedimento areno-argiloso, de coloração marrom acinzentada com fragmentos de conchas moídas em grande quantidade

Camada 5: sedimento areno-argiloso, de coloração acinzentada, associado a conchas inteiras de ostras e berbigões, semelhante a camada 3.

Camada 6: sedimento areno-argiloso, de coloração marrom acinzentada, com a presença de conchas fragmentadas e moídas, semelhante a camada 4. 


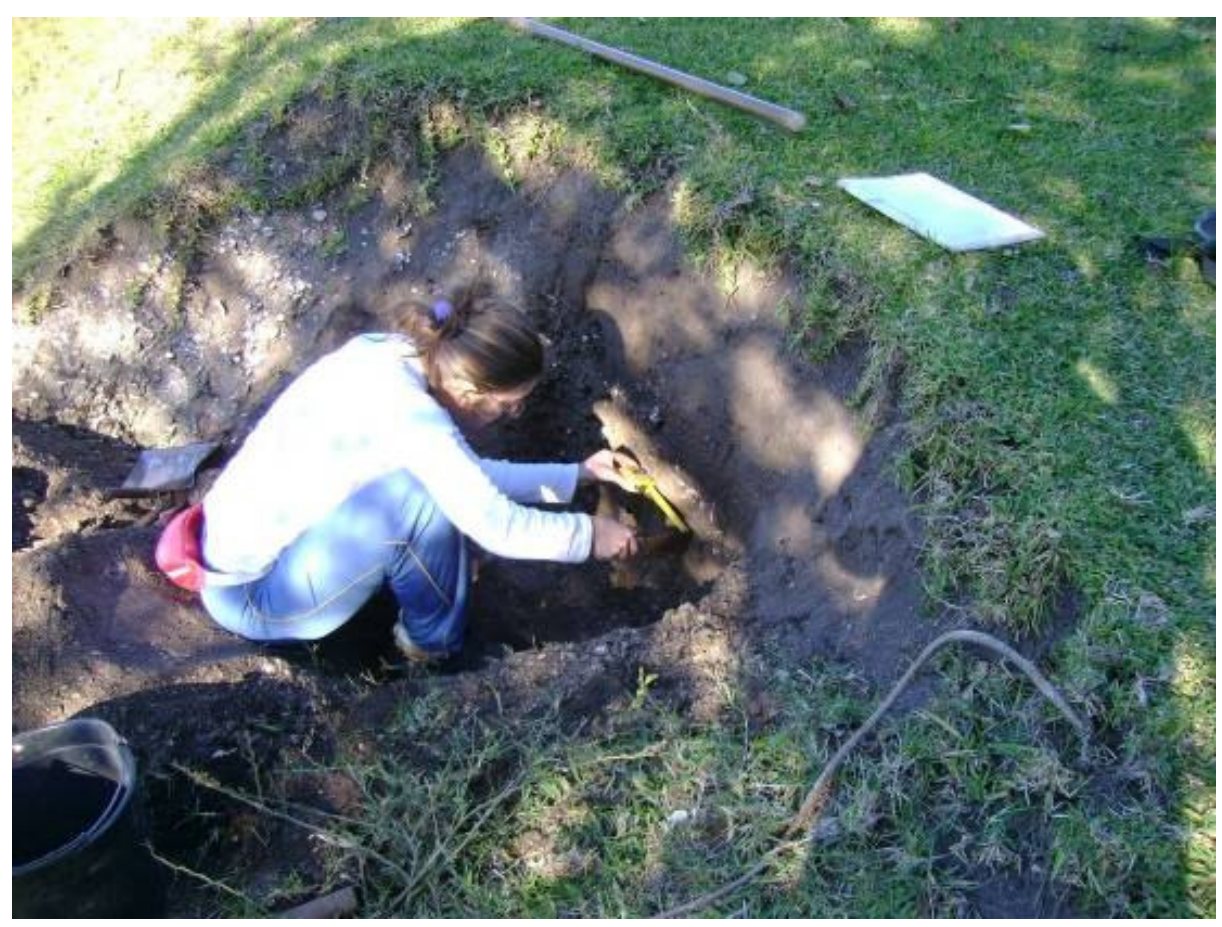

Fig. 20. Coleta zooarqueológica do perfil NW - Foto: Danilo Assunção

Perfil Norte (base do sambaqui) UTM (22J 0685973/68380

Camada 1: camada húmica. Sedimento areno-argiloso, de coloração negraacinzentada, com fragmentos de conchas moídas. Esta camada, pelo fato de apresentar as características das camadas húmicas comuns não foi contemplada com uma amostra zooarqueológica. Não acreditamos que ela seja parte da camada construtiva do sambaqui.

Camada 2: Sedimento areno-argiloso, de coloração acinzentada, com grande quantidade de conchas moídas e fragmentadas de ostras e berbigões.

Camada 3: sedimento argilo-arenoso, marrom acinzentado, com a presença de conchas inteiras e fragmentadas de ostras e berbigões.

Camada 4: sedimento argilo-arenoso, de coloração marrom, com a presença de conchas inteiras de lucinas, berbigões e ostras.

Camada 5: sedimento arenoso marrom claro, associado a conchas inteiras e fragmentadas de berbigões, ostras e lucinas.

Camada 6: sedimento argiloso de coloração negra, com pouca quantidade de conchas de ostras e berbigões. Aparece um sepultamento na base do sambaqui marcado com uma estrela no desenho do perfil abaixo. 
Os perfis foram confeccionados a partir de padrões definidos pela equipe do Projeto. Estes padrões se encontram no Anexo I da presente dissertação.

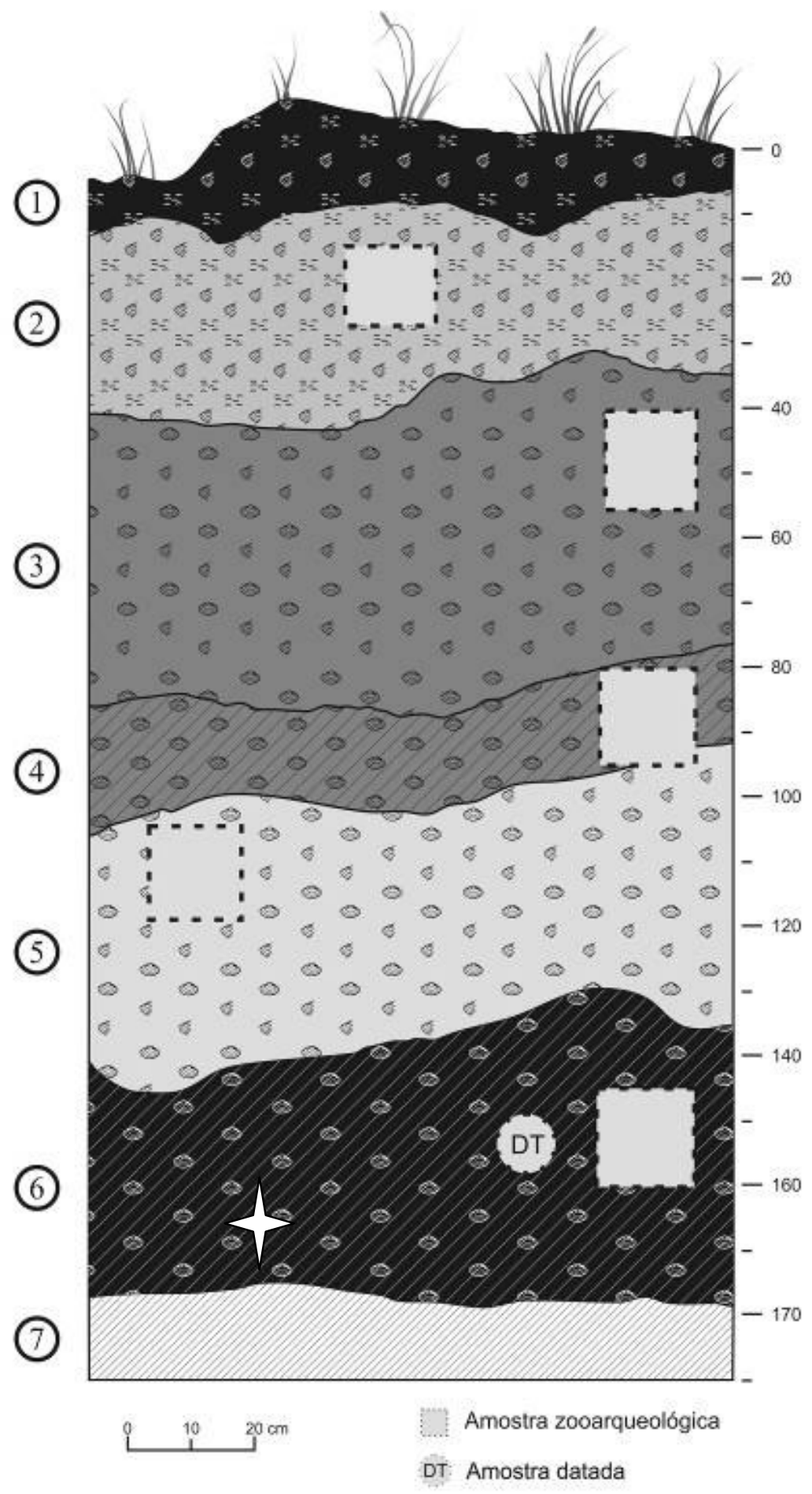

Fig. 21. Perfil norte Caipora. 


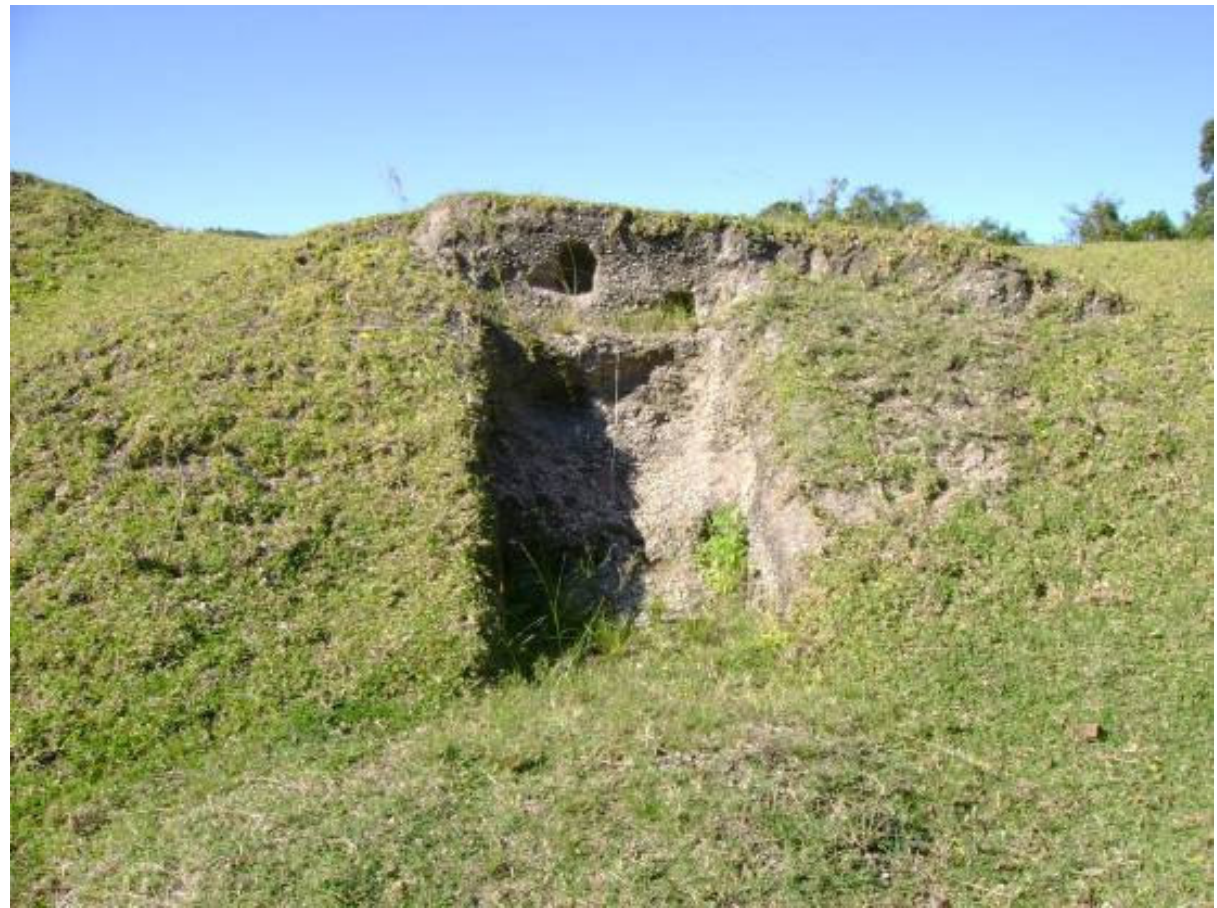

Fig. 22. Sambaqui Caipora Perfil Norte - Foto: Danilo Assunção

O sítio Caipora apresenta-se muito diferente do sítio Jaboticabeira I em sua composição. Neste, o elemento principal de construção do sítio é a Ostrea $s p$, e não a Anomalocardia, que não é muito expressiva, como será descrito no próximo capítulo, quando mostraremos os resultados das análises em laboratório.

\subsubsection{Sambaqui Lageado}

O proprietário do terreno e morador local sr. Renato iria aplainar seu terreno para a construção de uma casa e no momento em que passava o trator, diversos sepultamentos afloraram. Foi então que ele entrou em contato com a universidade UNISUL e esta mandou um estudante seu ao local para a confirmação do achado. Os sepultamentos (8) foram enviados para o laboratório do Grupo de Pesquisas em Educação Patrimonial e Arqueologia da UNISUL , o GRUPEP - Arqueologia para posterior análise.

Trata-se de um sambaqui bastante impactado antropicamente e localiza-se no município de Treze de Maio, mais especificamente no bairro Lageado, cujas coordenadas UTM são: (22J 0688352/6839863). O acesso ao sítio se dá pela estrada geral do bairro Lageado, próximo a BR 101. É um sítio de pequenas dimensões, com 60m de comprimento, 
$50 \mathrm{~m}$ de largura e aproximadamente $2 \mathrm{~m}$ de altura. Apresenta uma base ovalada e formato monticular.

Está implantado no vale do Rio Lageado, sobre um pequeno istmo cristalino às margens da planície quaternária sedimentar (antigo fundo de lagoa). A vegetação que recobre o sítio atualmente é composta por gramíneas e algumas poucas árvores de maior porte. Um pequeno açude foi construído às margens do sambaqui, aproveitando a nascente de água doce anexa ao sítio. Do sítio é possível avistar o morro das congonhas a nordeste, os cristalinos iniciais dos patamares da Serra Geral a oeste e a planície quaternária a leste, e em momento de transgressão marinha o acesso por canoas deve ter sido utilizado.

Em sua superfície pudemos encontrar diversos materiais líticos, como pedras de fogueira, fragmentos de lascamento em quartzo e rocha básica, além de batedores.

A escolha de trabalhar com este sítio se deveu ao fato deste se localizar próximo ao Sambaqui Caipora, estar implantado mais perto das encostas da Serra, pelo fato de sua datação ter resultado em mais um sítio muito antigo (5980 anos cal AP), e a sua conformação apresentar-se bastante parecida com o Caipora. Além disso, o proprietário nos mostrou uma coleção lítica impressionante retirada por ele no momento da retificação do terreno. Além de espátulas, quebra-coquinhos, um fuso muito bem polido e de dois objetos pontiagudos e polidos, ele nos mostrou um zoólito em forma de pássaro que teria sido encontrado ao lado da cabeça de um dos sepultamentos retirados por ele. 


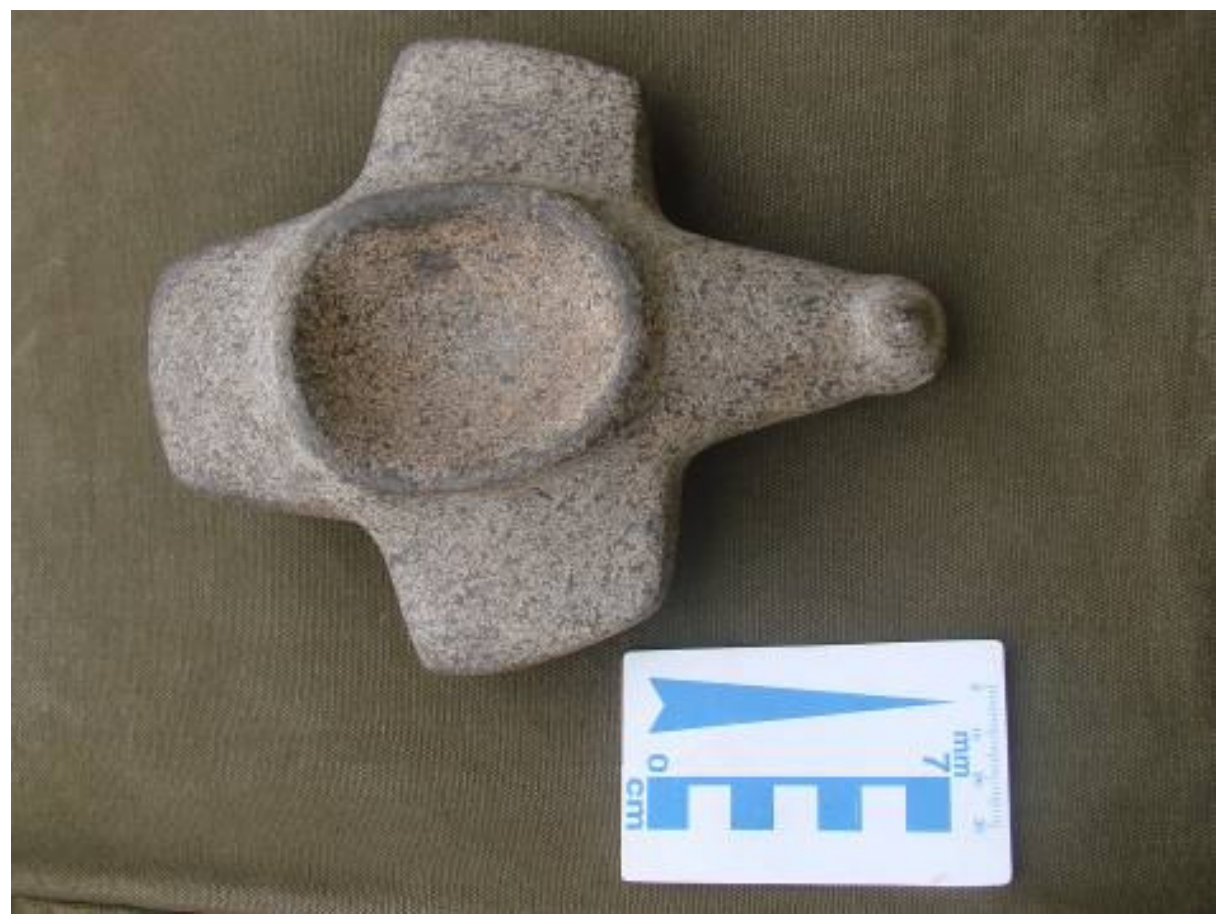

Fig. 23 - Zoólito em forma de pássaro encontrado pelo morador local ao lado de um sepultamento no sambaqui Lageado

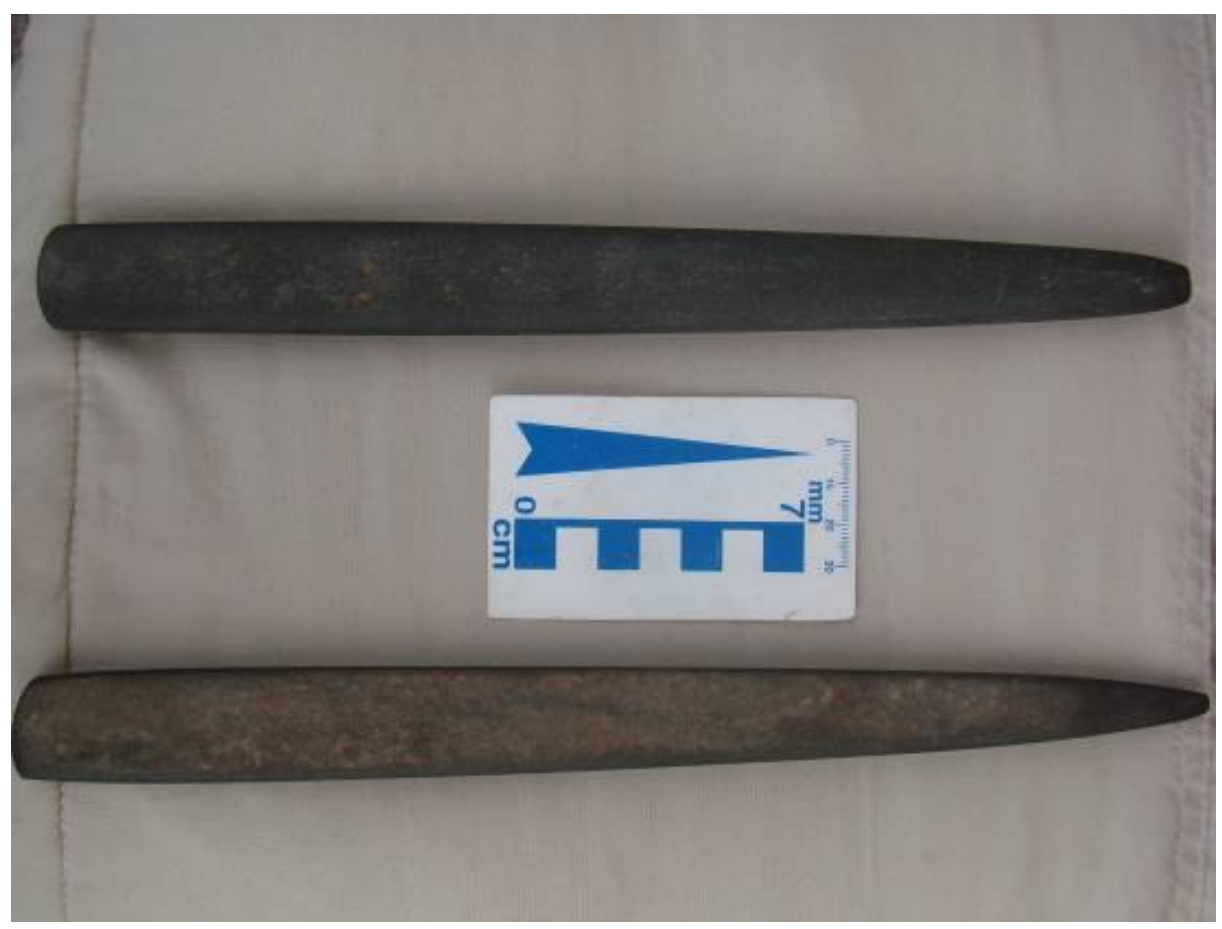

Fig. 24- Artefatos líticos encontrados no sambaqui Lageado 


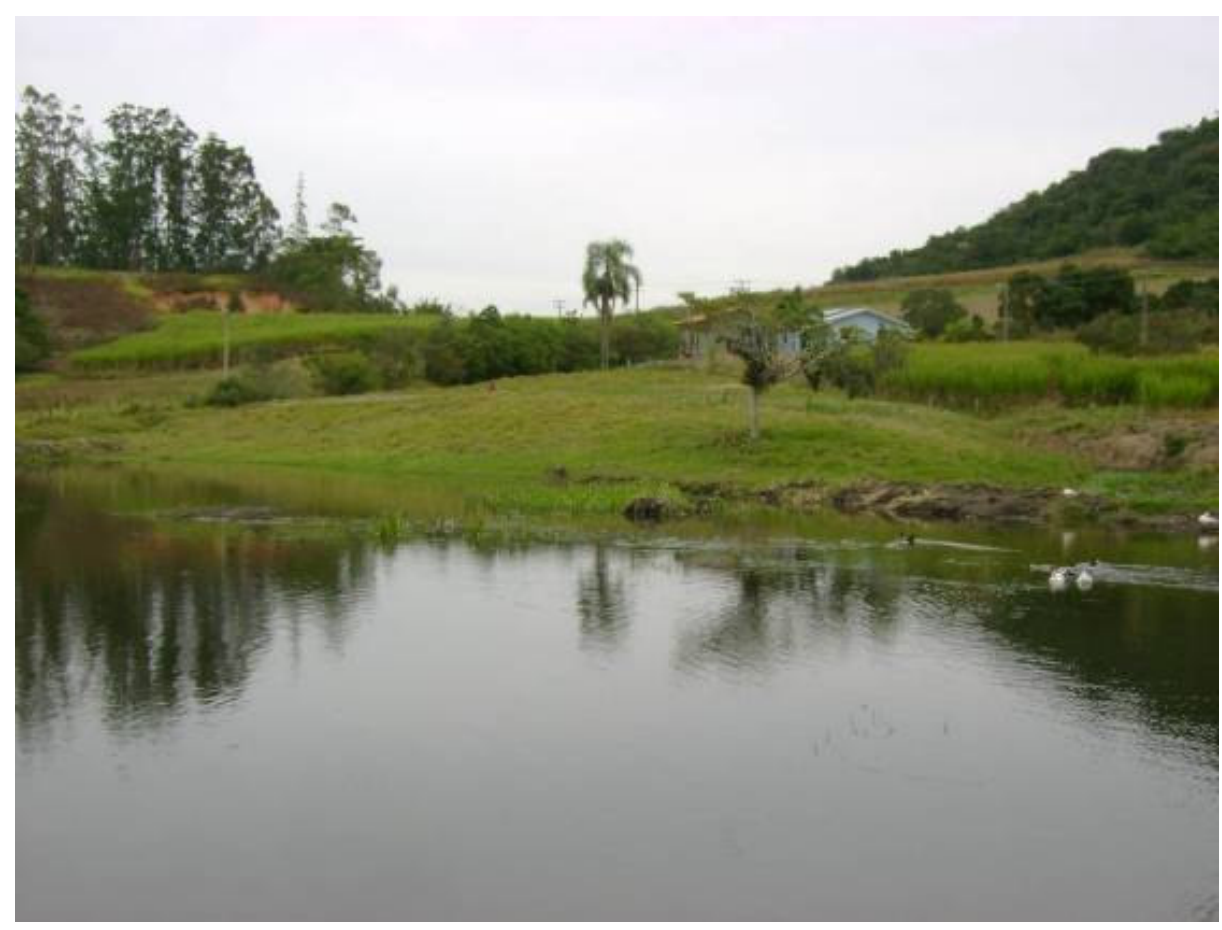

Fig. 25. Sambaqui Lageado - foto: Danilo Assunção

Os trabalhos realizados no sambaqui se restringiram a uma sondagem de $2 \mathrm{~m} \times 1 \mathrm{~m}$ na porção centro-leste do sítio, o suficiente para conseguirmos realizar coletas zooarqueológicas, de sedimento e de material para datação. Os perfis foram desenhados e fotografados. Nota-se claramente a presença maciça de conchas de ostra em detrimento de outras para a construção do sítio. 


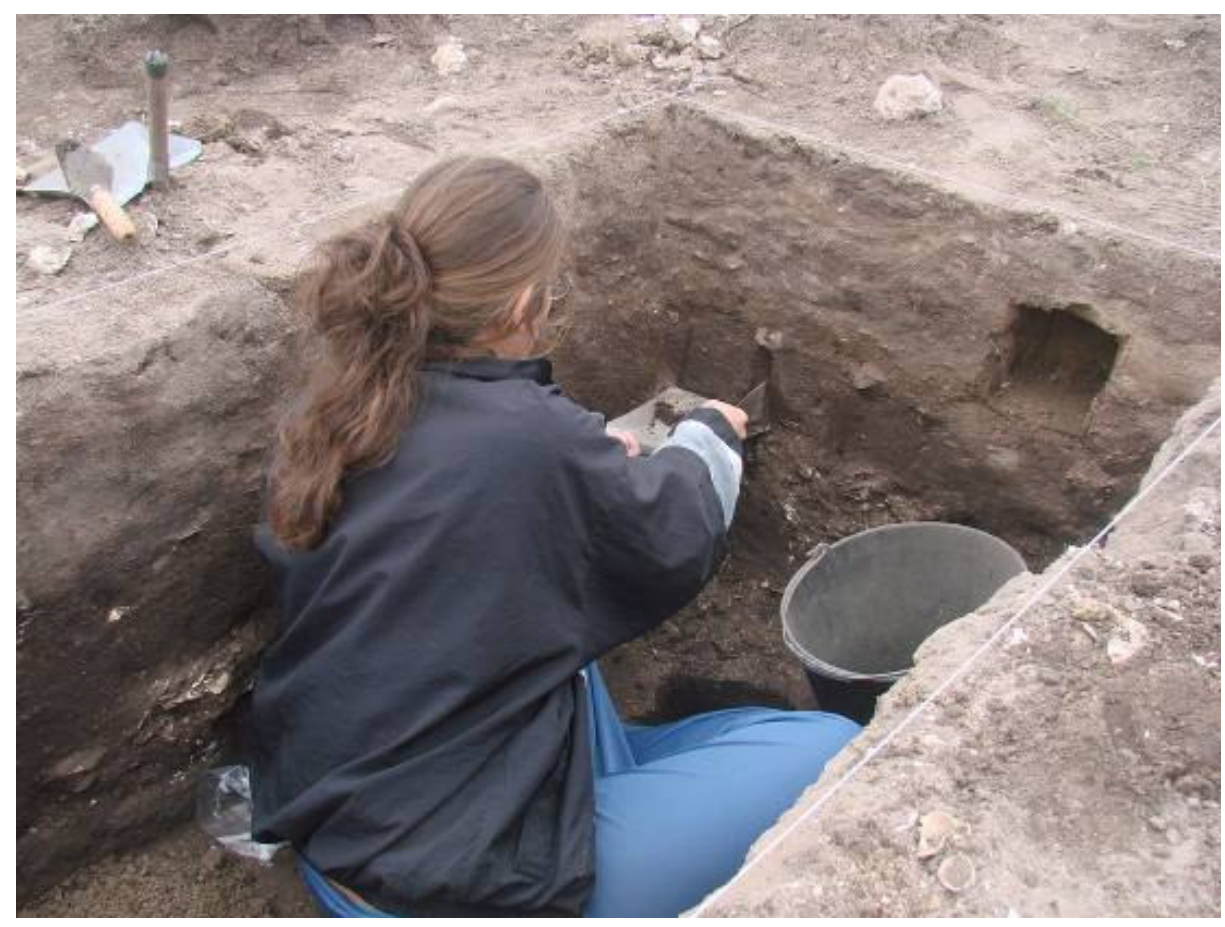

Fig. 26 . Coleta zooarqueológica do perfil E no sambaqui Lageado

Descrição das camadas Perfil Leste

Camada 1: sedimento areno-argiloso, de coloração bege escuro, com a presença de conchas de ostras e berbigões inteiras e fragmentadas e poucos ossos. A camada 1 foi considerada como resultante do impacto das escavações que o morador realizou e portanto não faz mais parte do sambaqui original. Consequentemente uma amostra para análise deste material não foi coletada.

Camada 2: sedimento argiloso, de coloração preta,composta de conchas de ostras inteiras e poucos ossos.

Camada 3: sedimento argiloso, de coloração marrom escura, sem a presença de conchas.

Camada 4: sedimento argiloso, de coloração preta,com a presença de conchas de ostra e berbigões inteiras e fragmentadas e poucos ossos.

Camada5: sedimento argiloso, de coloração marrom escura, sem a presença de conchas. 


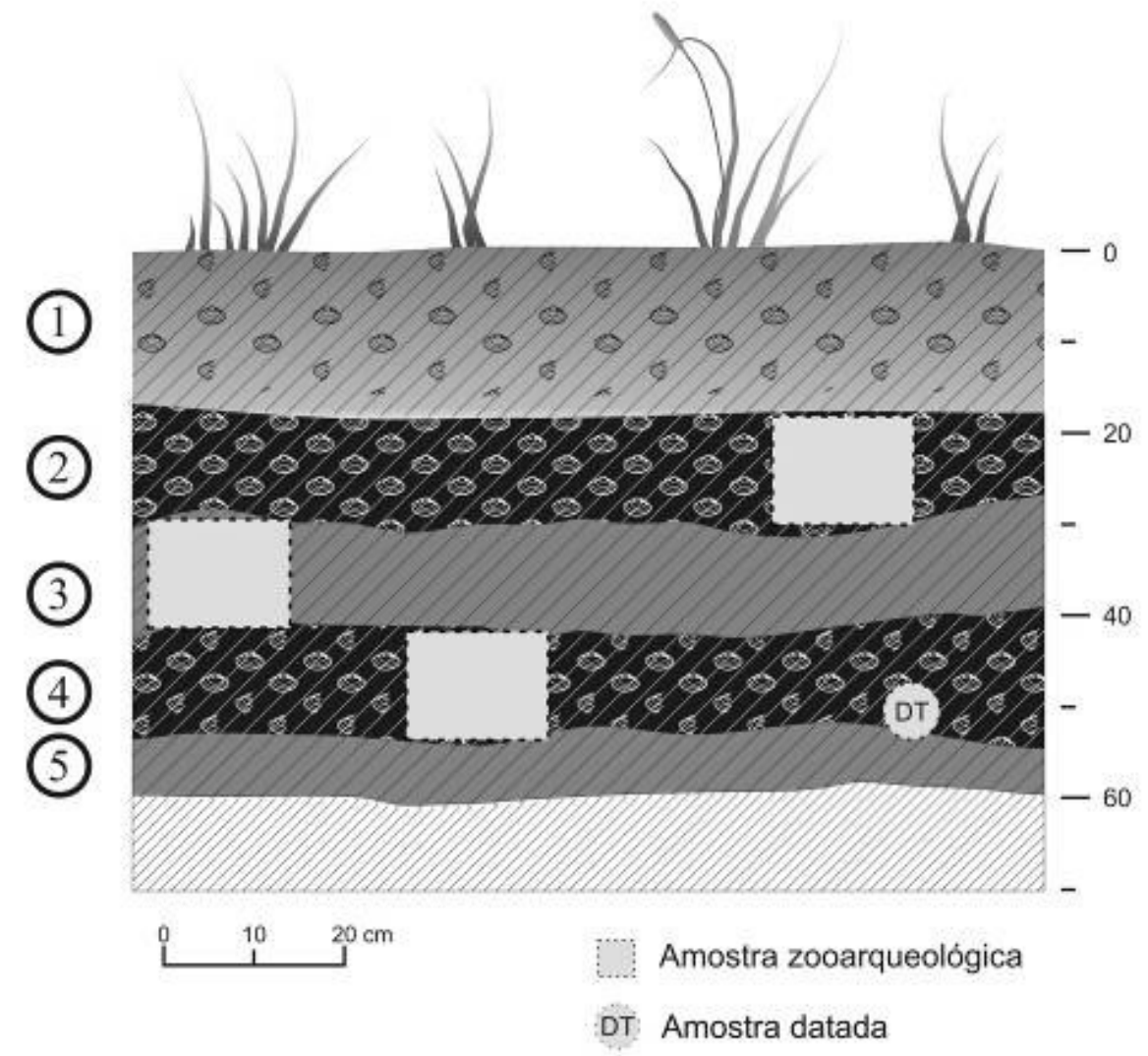

Fig. 27. Perfil leste Lageado

\subsubsection{Sambaqui Jaboticabeira I}

O Sambaqui Jaboticabeira I localiza-se no município de Jaguaruna, SC, no bairro da Jaboticabeira, em propriedade privada do Sr. Manoel Wendhausen Pereira. UTM (22J 0697349/6837715). O acesso ao sítio se dá através da estrada das congonhas, que liga a cidade de Jaguaruna aos bairros da praia, pelo caminho que corta o morro das Congonhas.

Este sambaqui situa-se próximo à Lagoa do Camacho, a aproximadamente $9 \mathrm{~km}$ a sul do mar, sobre uma linha de paleo dunas que está ancorada a um embasamento cristalino em meio a planície quaternária cercada de morros. Este sítio se encontra ao lado de um lençol conchífero que se estende pela planície charcosa quaternária da divisa entre Jaguaruna e Tubarão (rio das Congonhas) até a estrada do Camacho (SC 487), passando pelo sambaqui Jaboticabeira II, que se encontra a aproximadamente $3 \mathrm{Km}$ dali. 
A vegetação que recobre o sítio é composta por árvores de pequeno porte, mas bastante densas, o que consequentemente dificulta a visibilidade do entorno do sítio. A estratigrafia é bastante complexa, com espessas camadas de conchas que mergulham recobertas por outras mais horizontais, mostrando uma construção seqüencial e progressiva, com expansão para cima e também lateral. O Jaboticabeira I, segundo relatos de moradores locais foi um dos maiores sambaquis da região, e teria alcançado de 15 a 20 metros de altura. Ele foi minerado intensivamente para a extração de conchas para o fabrico de cal durante muitos anos, o que nos deixou menos de $25 \%$ do sítio intacto. Ainda sim ele apresenta grandes dimensões (400m de comprimento, $150 \mathrm{~m}$ de largura e aproximadamente $10 \mathrm{~m}$ de altura), o que confirma os relatos de que este teria sido um gigantesco sambaqui.

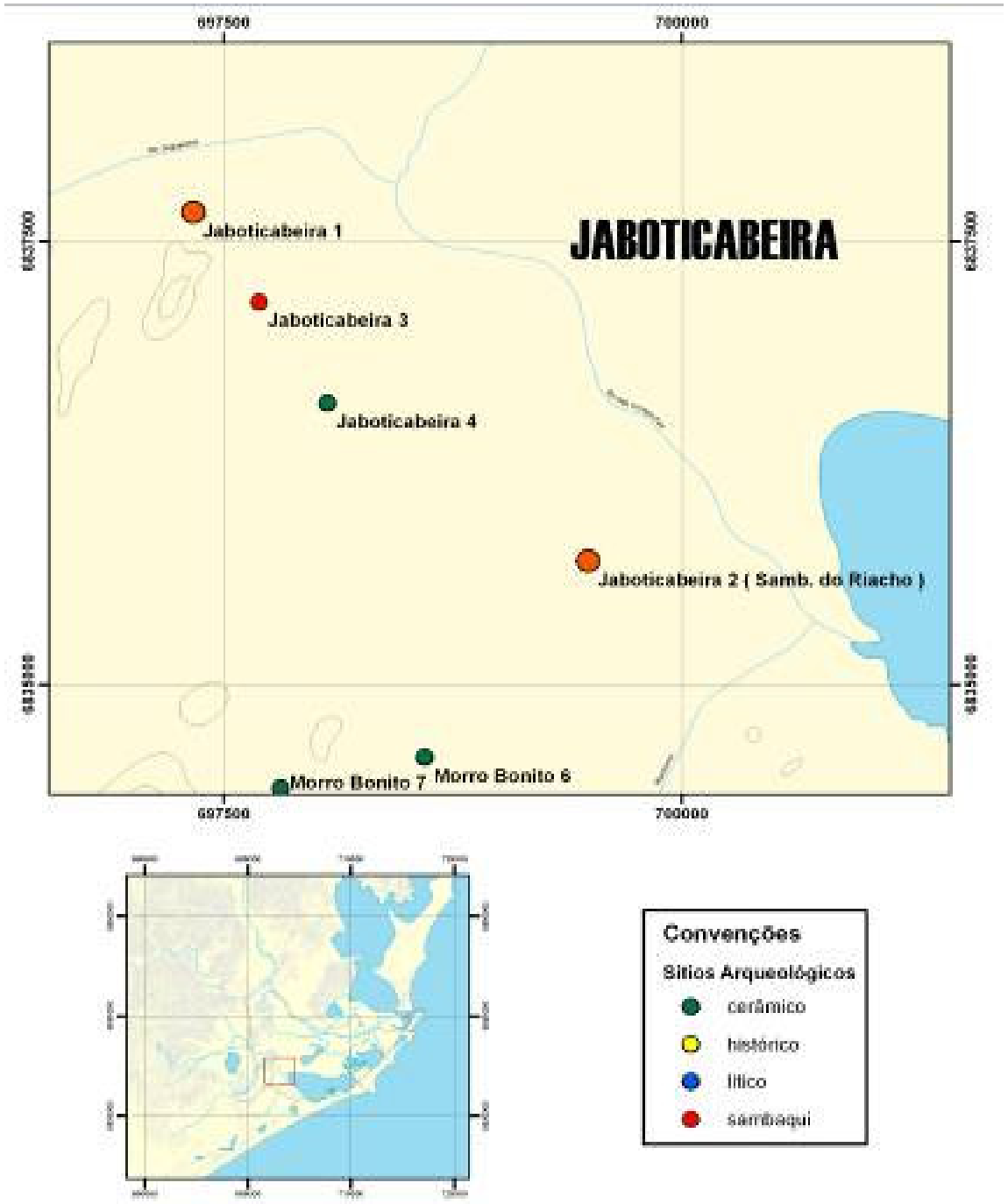

Fig. 28. Localidade da Jaboticabeira 
Campanhas realizadas no ano de 1999 pela equipe do projeto aproveitaram os grandes perfis deixados pela mineração do sambaqui para realizar a limpeza destes e seu registro, além de coletas de material para datação. Novamente, no ano de 2006 retornamos ao sítio, limpamos, fotografamos e redesenhamos os perfis para depois realizar as coletas zooarqueológicas para este trabalho. Estruturas de sepultamentos eram visíveis nos perfis, além de fogueiras. Quatro datações foram obtidas para este sítio, e vão de 4840 anos cal AP a 2750 anos cal AP, indicando um acúmulo de conchas realizado por quase dois mil anos, sem qualquer sinal de interrupção ou abandono do sítio.

Segundo informação dos moradores e mineradores locais que participaram da exploração econômica deste sambaqui, vários sepultamentos afloravam quando da extração das conchas, além de inúmeros artefatos líticos, inclusive um zoólito em forma de tubarão que mais tarde foi trocado por uma vaca entre os moradores e não se sabe mais seu paradeiro. Ainda segundo essas informações, este sítio apresentava uma camada preta muito parecida com a que ocorre no Jaboticabeira II, que recobria o sítio e apresentava muitos sepultamentos. Como o sítio foi muito explorado, não restou nada referente às camadas de topo para averiguarmos essa informação.

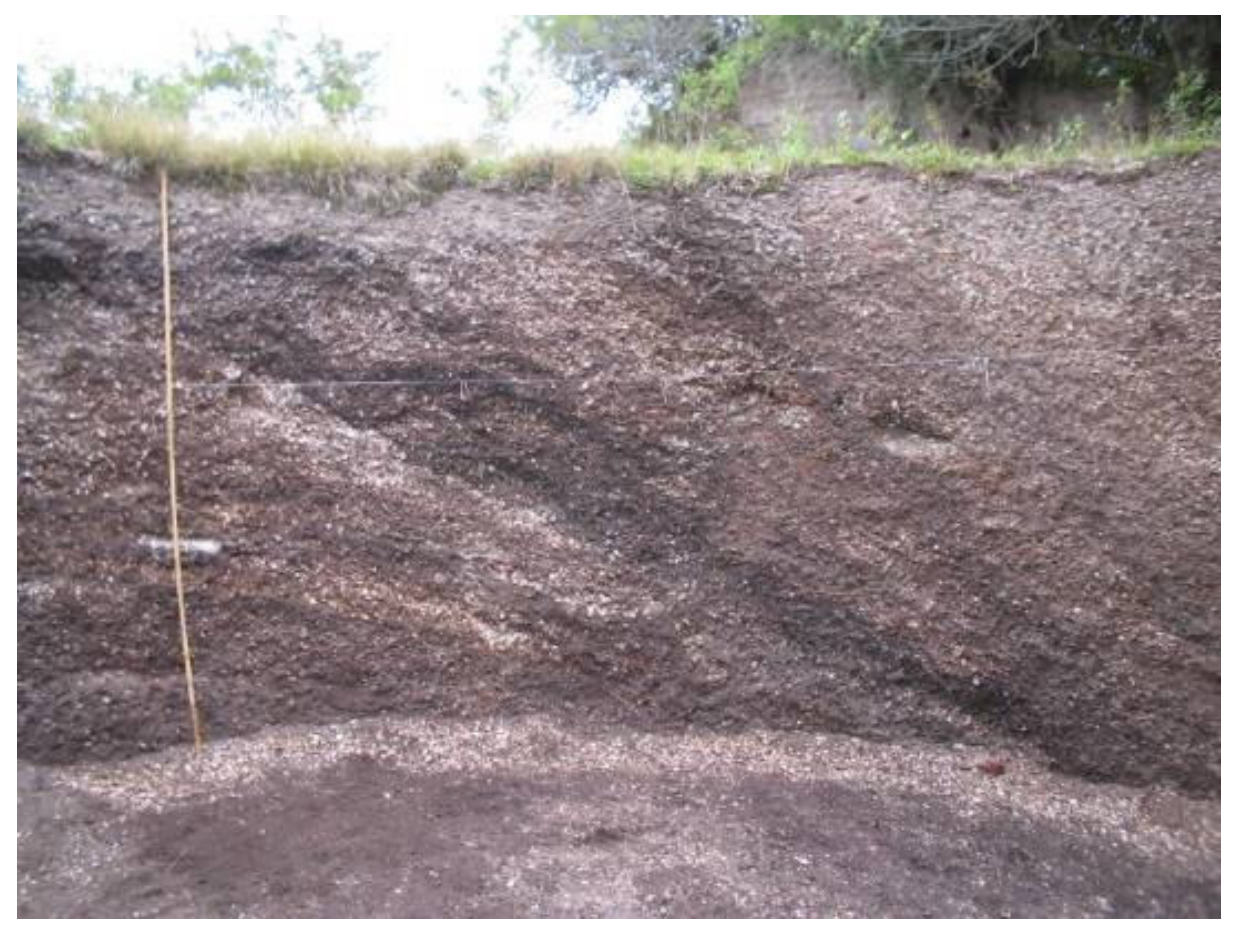

Fig. 29. Perfil oeste do sambaqui Jaboticabeira I- foto: Danilo Assunção 


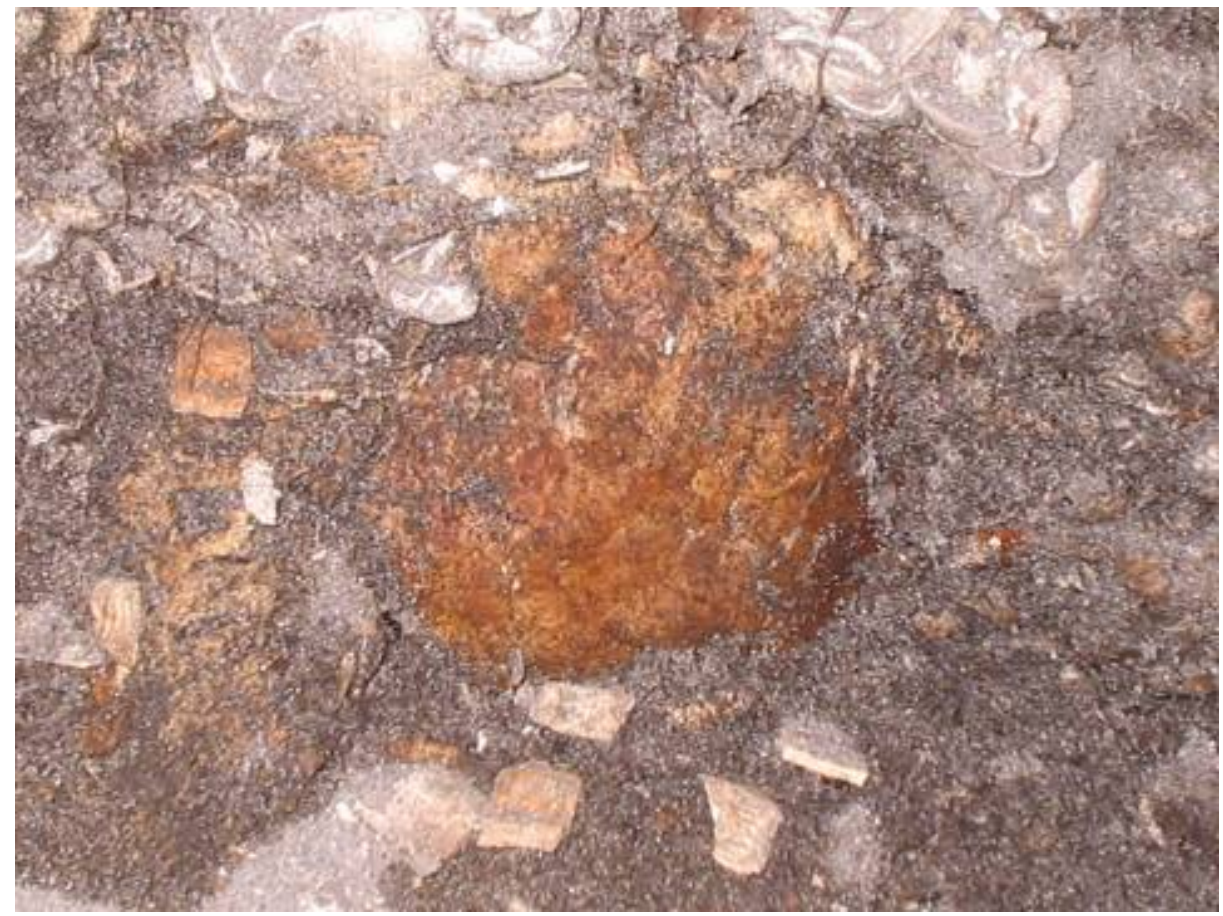

Fig 30. Crânio aparente na base do sambaqui (camada 2) cercado por placas de tatu

\section{Descrição das camadas estratigráficas do Jaboticabeira I}

Perfil 1 -Oeste (base do sambaqui) UTM: (22J 0697403/6837707)

Camada 1: sedimento arenoso de coloração escura, com a presença de conchas de berbigão inteiras e fragmentadas. (60\% sedimento, $40 \%$ conchas);

Camada 2: sedimento arenoso de coloração escura, com a presença de conchas de berbigão inteiras e fragmentadas, algumas queimadas.(60\% concha,40\% sedimento);

Camada 3: sedimento arenoso escuro, com a presença de ossos de peixe, fragmentos de carvão e conchas predominantemente de berbigão, mas há também a presença de ostras e caramujos, muitos queimados. Até os $50 \mathrm{~cm}$, a camada apresenta maior quantidade de ossos de peixe do que conchas ( $80 \%$ ossos de peixe) e daí pra frente a proporção se inverte. Sobre esta camada se encontra uma lente de carvão;

Camada 4: sedimento arenoso escuro, com a presença de conchas de berbigão, algumas queimadas. (50\% conchas, $50 \%$ sedimento); 
Camada 5: camada composta quase exclusivamente de conchas de berbigão não queimadas e inteiras, com pouco sedimento entremeado(95\% conchas);

Camada 6: camada de sedimento enegrecido, arenoso, com a presença de conchas de berbigão inteiras, além de fragmentos de carvão (50\% conchas, $50 \%$ sedimento);

Camada 7: camada composta por conchas de berbigão não queimadas, com pouco sedimento entre elas. O sedimento é arenoso e seu principal componente são conchas moídas. Há também a presença de carvão e fragmentos esparsos de ossos de peixe (90\% conchas, $10 \%$ sedimento);

Camada 8: camada composta por conchas inteiras de berbigão, algumas queimadas, entremeadas por ossos de peixe. Sua coloração é amarelada, e contem fragmentos de carvão e ostra ( $70 \%$ conchas)

Camada 9: sedimento arenoso marrom escuro, com a presença de conchas inteiras de berbigões e fragmentos de carvão (60\% conchas);

Camada 10: camada composta por conchas de berbigão inteiras e não queimadas, entremeadas por sedimento arenoso cinzento. Presença de fragmentos de carvão e conchas de mariscos (50\% sedimento, $50 \%$ conchas);

Camada 11: camada composta por conchas de berbigão inteiras, algumas queimadas, entremeadas por muitos ossos de peixe, o que lhe confere uma coloração alaranjada. Há também fragmentos de carvão ( $60 \%$ fauna, $40 \%$ conchas e sedimento);

Camada 12: camada composta por conchas de berbigão inteiras em sua maior parte, não queimadas e entremeadas por sedimento arenoso bege claro ( $70 \%$ conchas);

Camada 13: camada composta por sedimento areno-argiloso bege escuro com conchas de berbigão inteiras e não queimadas (60\% sedimento, $40 \%$ conchas);

Camada 14: camada composta por sedimento areno-argiloso acinzentado, associado a conchas de berbigão e Thais haemastoma inteiras e fragmentadas (50\% conchas, $50 \%$ sedimento);

Camada 15: camada composta por sedimento argilo-arenoso cinzento, com conchas fragmentadas e inteiras de ostras e berbigões (75\% sedimento, $25 \%$ conchas);

Camada 16: camada composta por conchas de ostras e berbigões, inteiras e fragmentadas, envolta em sedimento areno-argiloso cinzento claro (75\% conchas); 


\section{Feições:}

A) Lente de carvão recoberta por areia branca fina de praia.

B) Lente de ossos de peixe e conchas de berbigão queimados, com fragmentos de carvão.

C) Lente de carvão recoberta por areia branca fina de praia.

D) Feição composta por conchas de berbigão inteiras, com praticamente nenhum sedimento entremeado.

E) Lente de fragmentos de conchas calcinadas de coloração cinza.

F) Lente de fragmentos de conchas calcinadas de coloração cinza, entremeados por sedimento duro e pouco friável, areno-argiloso, de coloração alaranjada.

G) Lente de ossos de peixe, de coloração alaranjada com fragmentos de carvão e conchas de berbigão queimadas.

H) lente de fragmentos de conchas calcinadas e muito compactada, com coloração cinza.

Um sepultamento aparece na base do sambaqui, na camada 2. 


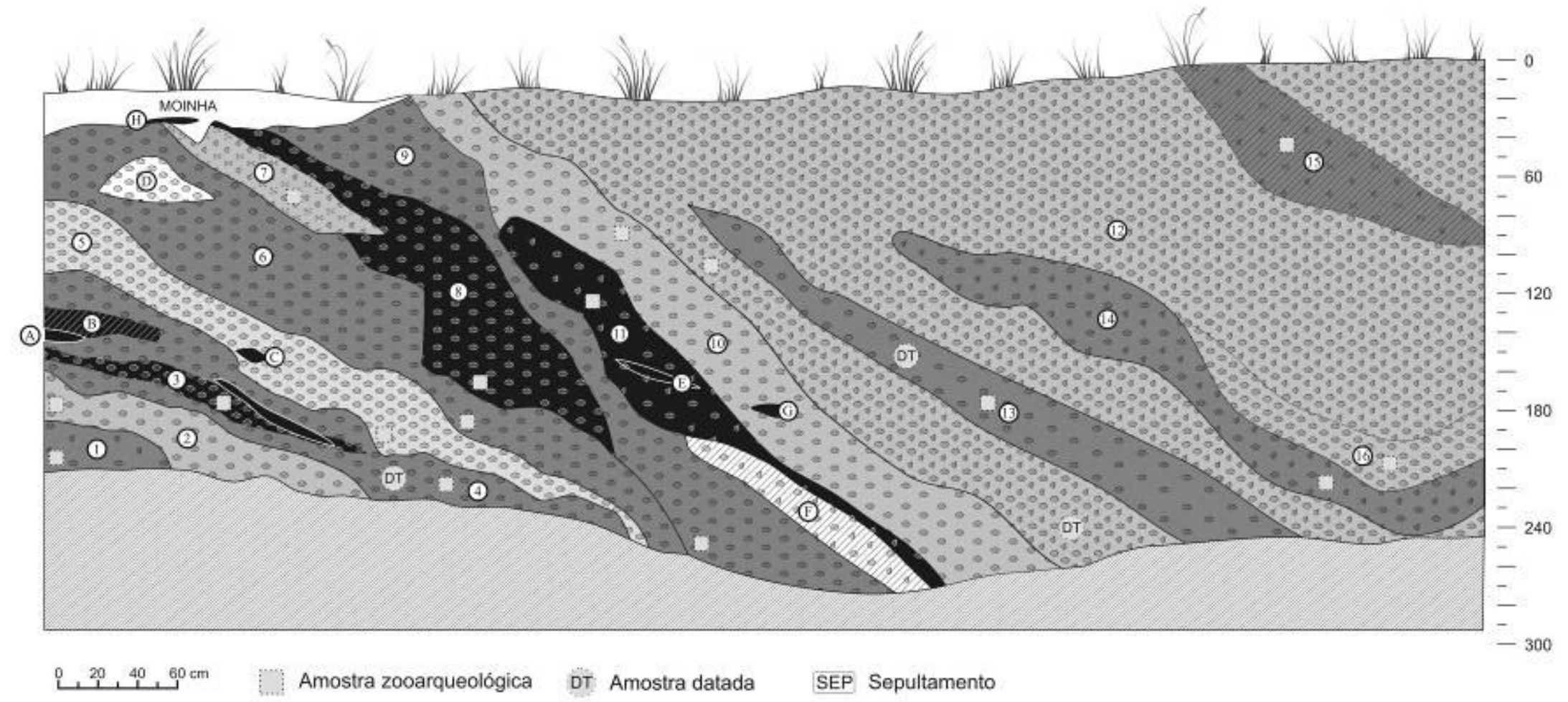

Fig. 31. Perfil oeste do Jab I 


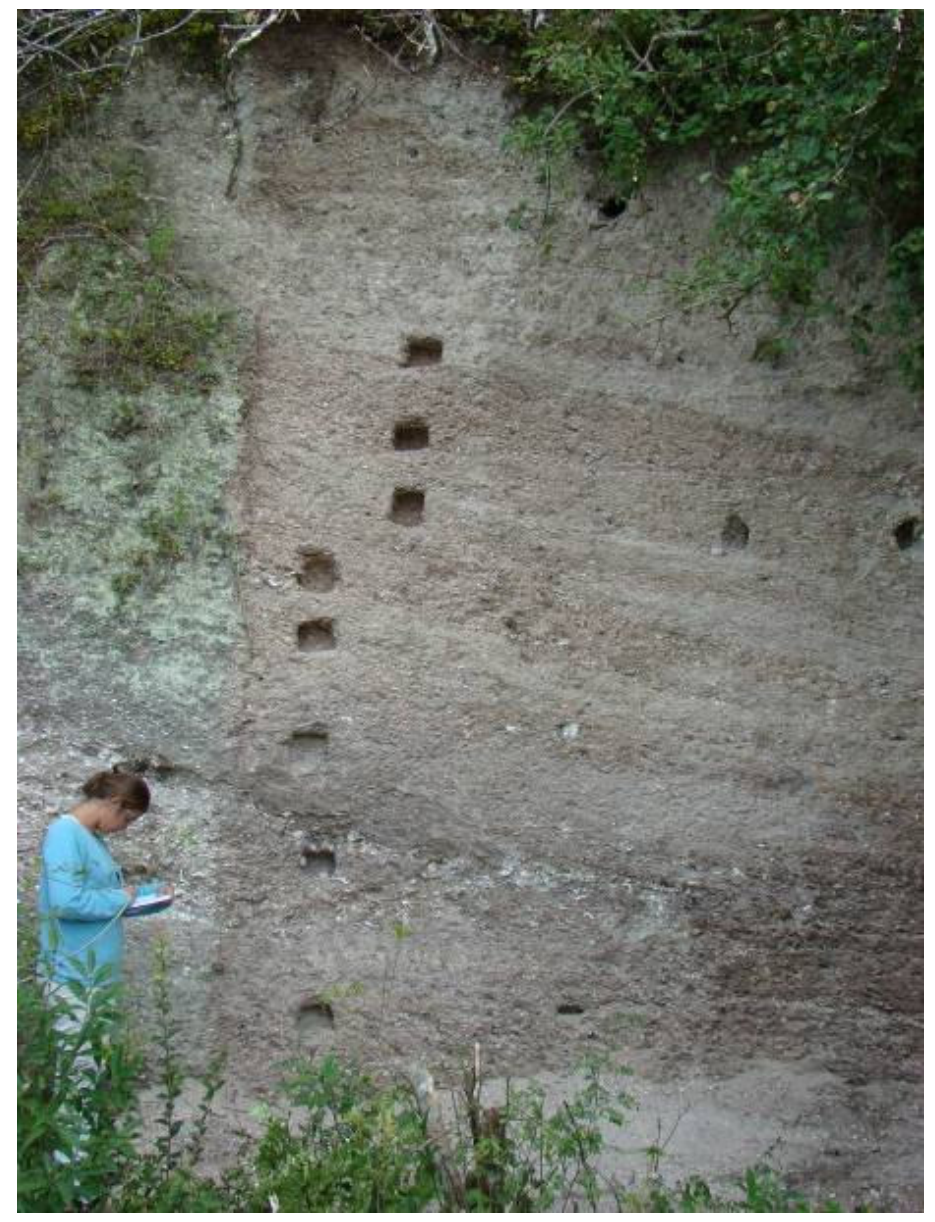

Fig. 32. Perfil Sul do Jaboticabeira I - Foto: Danilo Assunção

Camada 17: camada bastante compactada composta por sedimento arenoso cinza claro, com a presença de conchas inteiras de berbigão e ostras, com poucos ossos de peixe e carvão.

Camada 18: camada composta por conchas de ostras inteiras e fragmentadas. Também há a presença de berbigões e muito pouco carvão.

Camada 19: camada composta por berbigões fragmentados, muito compactada, quase como uma concreção.

Camada 20: camada composta por um sedimento muito compactado, com a presença de conchas de Thais haemastoma, berbigões e ostras. As conchas aparecem muito fragmentadas e há pouco sedimento entre elas. 
Camada 21: camada composta por sedimento arenoso entre as conchas de berbigão, ostra, fragmentos de carvão e ossos de peixe. As ostras inteiras ocupam os primeiros 10 centímetros das camadas.

Camada 22: camada composta por sedimento areno-argiloso com a presença de ossos de peixes, carvão, berbigões inteiros e fragmentados e também muito marisco.

Camada 23: camada composta por sedimento arenoso com a presença de conchas de berbigão inteiras, fechadas e algumas fragmentadas, além de fragmentos de ossos de peixe e carvão.

Camada 24: camada composta por sedimento arenoso claro, com a presença de fragmentos de conchas de gastrópodes e berbigões, além de fragmentos de ossos de peixe.

O sepultamento aparece na base da camada18. 

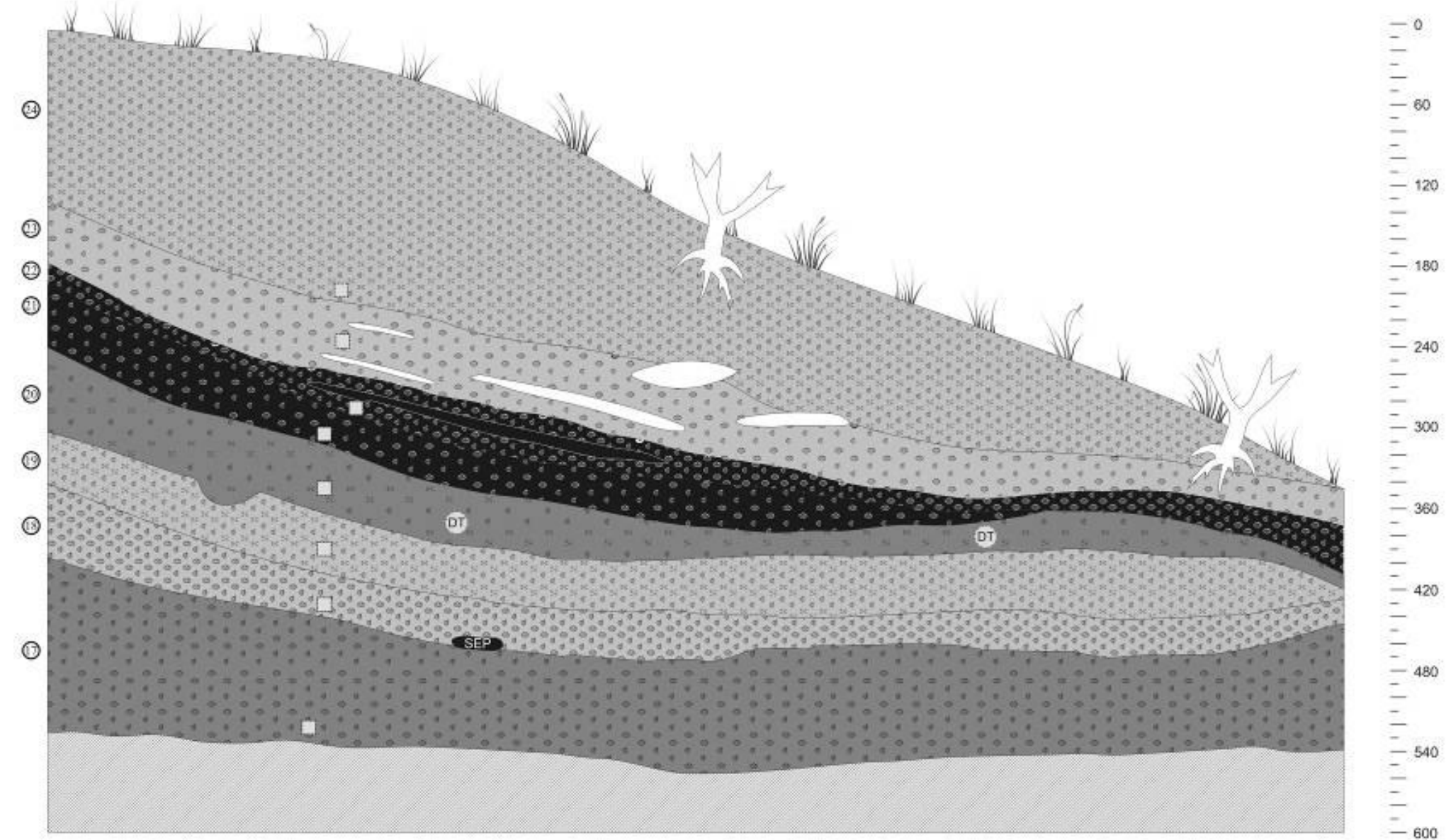

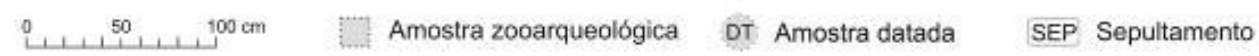

Fig. 33. Perfil sul do Jab 1 . 


\section{Cap. V Apresentação dos resultados}

A análise dos vestígios faunísticos dos sítios Jaboticabeira I, Caipora e Lageado resultou em diversos gráficos e tabelas que serão apresentados a seguir. Os três sítios estudados neste trabalho fazem parte da historia de ocupação dos grupos sambaquieiros no litoral sul do estado de Santa Catarina, apresentando-se de diferentes maneiras em relação ao seu conteúdo malacológico, faunístico, cronológico e de implantação na paisagem.

\subsection{O Sítio Caipora}

O sambaqui Caipora, UTM: (22J 0685972/ 6838075) é um sambaqui de médias dimensões, de aproximadamente $25 \mathrm{~m}$ x 20 × $3 \mathrm{~m}$. Está ancorado em um afloramento granítico, as margens do que hoje é o rio Caipora retificado. Localiza-se bem próximo as encostas da Serra, em meio a um terreno alagadiço utilizado como pasto atualmente pelo proprietário do terreno.

A tabela abaixo apresenta os componentes encontrados em todas as camadas amostradas no sítio e a representatividade de cada um deles na composição do sambaqui.

\begin{tabular}{|c|c|c|c|}
\hline Material & Peso Total & Material & Peso Total \\
\hline Carvão & $0,008 \%$ & Crepidula $\mathrm{sp}$ & $0,291 \%$ \\
\hline Megalobulimus sp & $0,012 \%$ & Chione sp & $0,365 \%$ \\
\hline Olivela sp e Olivancelaria $\mathrm{sp}$ & $0,030 \%$ & Vermetídeo & $0,389 \%$ \\
\hline Cyrtopleura sp & $0,041 \%$ & Ossos & $0,435 \%$ \\
\hline Mesodesma sp & $0,042 \%$ & Neritina virginea & $0,545 \%$ \\
\hline Craca & $0,045 \%$ & Pinctada radiata & $0,718 \%$ \\
\hline caramujo terrestre & $0,050 \%$ & Gastrópodes & $2,153 \%$ \\
\hline Trachycardium muricatus & $0,070 \%$ & Artefato lítico & $2,563 \%$ \\
\hline Sanguinolaria sp & $0,117 \%$ & Marisco & $3,796 \%$ \\
\hline Atrina seminuda & $0,128 \%$ & Anomalocardia brasiliana & $10,475 \%$ \\
\hline Macoma sp & $0,190 \%$ & Rochas & $25,468 \%$ \\
\hline Outros & $0,200 \%$ & Ostrea $\mathrm{sp}$ & $51,667 \%$ \\
\hline Lucina pectinata & $0,203 \%$ & *Nassarius sp, Cerithium at & gilina morio \\
\hline
\end{tabular}

Tabela 2. Sítio Caipora - Perfil Norte. Componentes da matriz sedimentar. 


\begin{tabular}{|lllr}
\multicolumn{1}{c}{ Material } & Peso Total & \multicolumn{1}{c}{ Material } & Peso Total \\
\hline Concreção & $0,001 \%$ & Crepidula sp & $0,190 \%$ \\
\hline Olivela sp e Olivancelaria sp & $0,002 \%$ & Chione sp & $0,263 \%$ \\
\hline Trachycardium muricatus & $0,004 \%$ & Marisco & $0,440 \%$ \\
\hline Litorina sp & $0,008 \%$ & Ossos & $0,530 \%$ \\
\hline Pinctada radiata & $0,011 \%$ & Lucina pectinata & $0,541 \%$ \\
\hline Dusinia sp & $0,018 \%$ & Neritina virginea & $0,594 \%$ \\
\hline Vermetídeo & $0,022 \%$ & Macoma sp & $0,624 \%$ \\
\hline Craca & $0,025 \%$ & Gastrópodes & $2,598 \%$ \\
\hline Argila & $0,039 \%$ & Anomalocardia brasiliana & $13,059 \%$ \\
\hline Thais haemastoma & $0,043 \%$ & Rochas & $38,342 \%$ \\
\hline Outros & $0,090 \%$ & Ostrea sp & $42,458 \%$ \\
\hline Mesodesma sp & $0,098 \%$ & *Nassarius sp, Cerithium atratus, Pugilina morio \\
\hline
\end{tabular}

É possível notar a alta expressividade de Ostrea sp na matriz conchífera do sambaqui, em ambos os perfis. A segunda categoria de maior expressividade são as rochas, com praticamente $30 \%$ do total dos componentes que compõe o sambaqui. A grande presença de rochas (estas são caracterizadas como fragmentos de granito em decomposição) pode ser explicada pelo motivo das ostras encontradas no sítio serem provenientes de costões rochosos, o que significa que os fragmentos de rochas graníticas estão sendo colocados no sítio por que vêm incrustados nas conchas de ostras. Muitas das conchas analisadas em laboratório apresentavam fragmentos de granito presas às valvas. O terceiro componente é a Anomalocardia, com pouco mais de $13 \%$ do total das conchas do sítio. A quantidade de ossos presente nas amostras deste sítio é muito pequena, não atingindo sequer uma porcentagem significativa nas amostras. A categoria outros indica fragmentos de conchas não identificadas.

\begin{tabular}{|c|c|c|c|}
\hline Material & Total & Material & Total \\
\hline origem diversa & $0,02 \%$ & marisco & $2,70 \%$ \\
\hline ossos & $0,47 \%$ & gastrópodes & $2,94 \%$ \\
\hline outros & $0,47 \%$ & Anomalocardia brasiliana & $11,32 \%$ \\
\hline artefato lítico & $1,73 \%$ & rochas & $29,65 \%$ \\
\hline outros bivalves & $2,03 \%$ & Ostrea $s p$ & $48,67 \%$ \\
\hline
\end{tabular}

Tabela 4 - Porcentagem dos componentes da matriz sedimentar do sítio Caipora 


\section{Caipora}

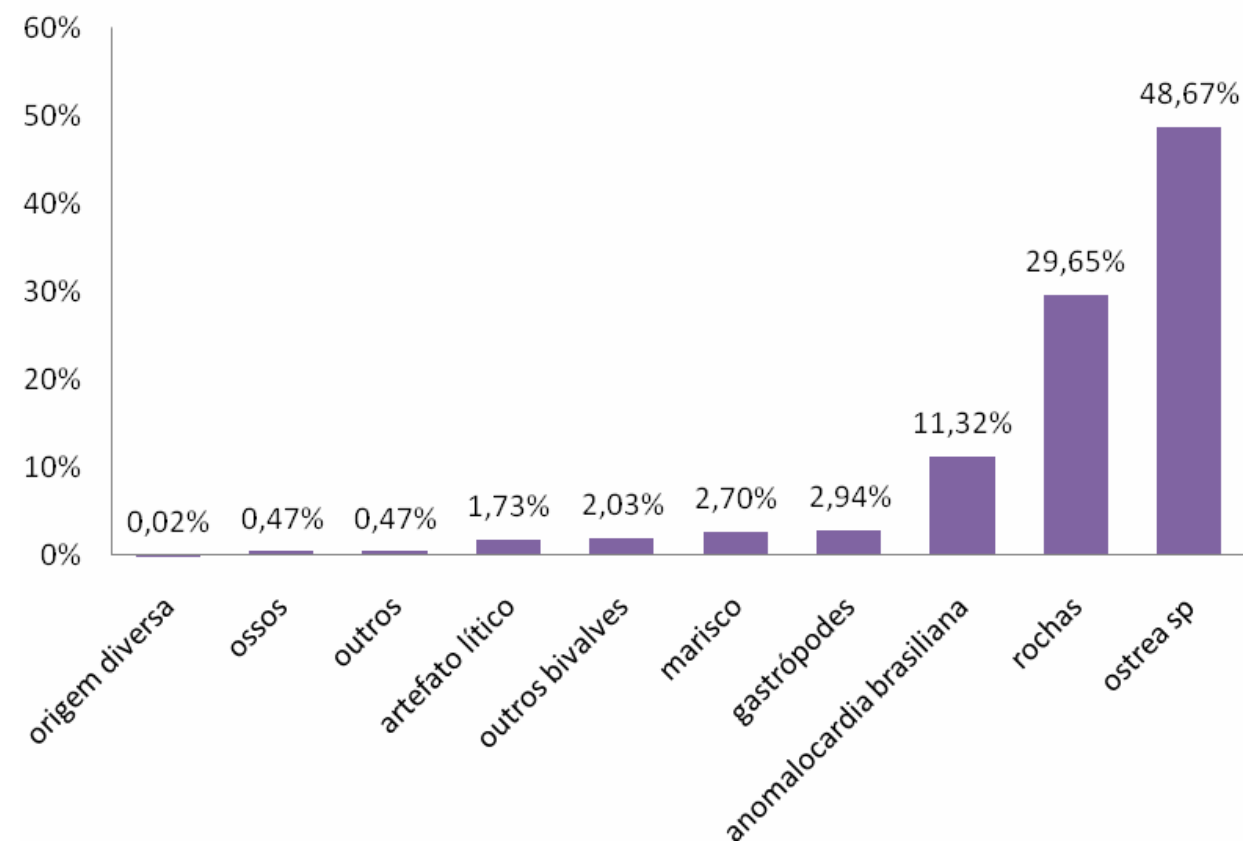

Fig. 34. Porcentagem dos componentes da matriz sedimentar do sítio Caipora

Estes gráfico (Fig. 34) e tabela (tab 4) representam todo o material analisado do sítio, dos dois perfis. Dessa maneira é possível confirmar o majoritismo da Ostrea sp em relação aos outros componentes das camadas do sítio, seguido das rochas e depois pela Anomalocardia.

\begin{tabular}{|c|r|r|r|}
\hline \multicolumn{4}{|c|}{ Caipora - Perfil Noroeste } \\
\hline P1 - Total $(\mathrm{g})$ & \multicolumn{2}{|c|}{$18.710,00$} & $100 \%$ \\
\hline P2 - Total $(\mathrm{g})$ & \multicolumn{2}{|c|}{$2.279,04$} & $12 \%$ \\
\hline Camada & P1 (g) & P2 (g) & P2 (\%) \\
\hline 1 & $4.232,00$ & 288,46 & $6,82 \%$ \\
\hline 2 & $3.196,00$ & 135,86 & $4,25 \%$ \\
\hline 3 & $3.216,00$ & 716,76 & $22,29 \%$ \\
\hline 4 & $4.210,00$ & 333,67 & $7,93 \%$ \\
\hline 5 & $3.856,00$ & 804,29 & $20,86 \%$ \\
\hline
\end{tabular}

Tabela 5. Peso inicial (P1) e peso do material triado (P2) do Perfil NW, e suas porcentagens relativas a cada camada. 


\begin{tabular}{|c|r|r|r|}
\hline \multicolumn{4}{|c|}{ Caipora - Perfil Norte } \\
\hline P1 - Total (g) & $26.416,00$ & $(\%)$ & $100 \%$ \\
\hline P2 - Total (g) & $4.728,45$ & $(\%)$ & $17,90 \%$ \\
\hline Camada & P1 (g) & P2 (g) & P2 (\%) \\
\hline 2 & $5.320,00$ & 846,88 & $15,92 \%$ \\
\hline 3 & $5.228,00$ & 989,04 & $18,92 \%$ \\
\hline 4 & $5.170,00$ & 993,49 & $19,22 \%$ \\
\hline 5 & $5.184,00$ & 820,40 & $15,83 \%$ \\
\hline 6 & $5.514,00$ & $1.078,64$ & $19,56 \%$ \\
\hline
\end{tabular}

Tabela 6. Peso inicial (P1) e peso do material triado (P2) do Perfil N, e suas porcentagens relativas a cada camada.

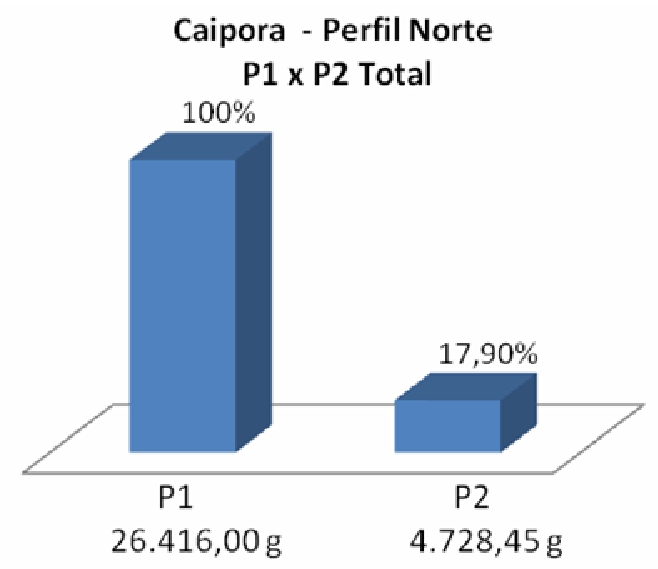

Fig. 35. Sítio Caipora. Porcentagem do Material triado do Perfil N

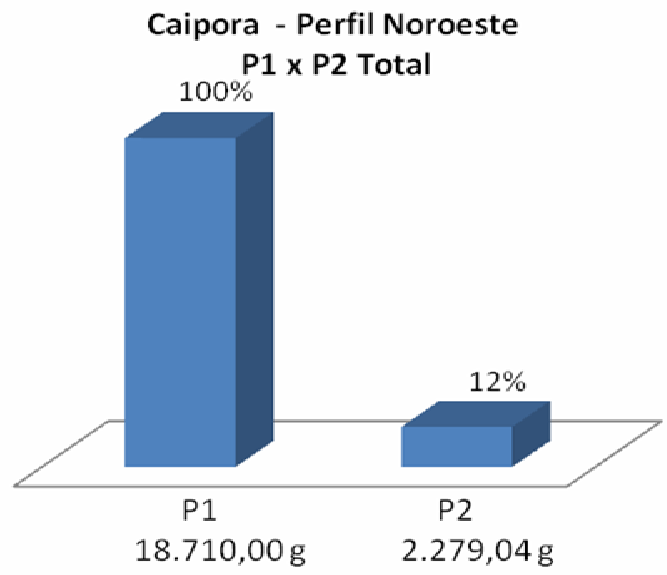

Fig. 36. Sítio Caipora. Porcentagem do Material triado do Perfil NW 
Em relação à quantidade de material triado, ou seja, a relação entre sedimento terroso que no momento da lavagem do material foi perdido e o material faunístico efetivamente analisado, é possível notar a pequena quantidade de conchas e ossos em relação ao total do peso da amostra (12\%). Este fato pode ser explicado dado que este sambaqui é composto de muito sedimento terroso entremeado ao material conchífero construtivo do sitio, além das conchas apresentarem-se muito fragmentadas, o que diminui o tamanho da amostra analisada.

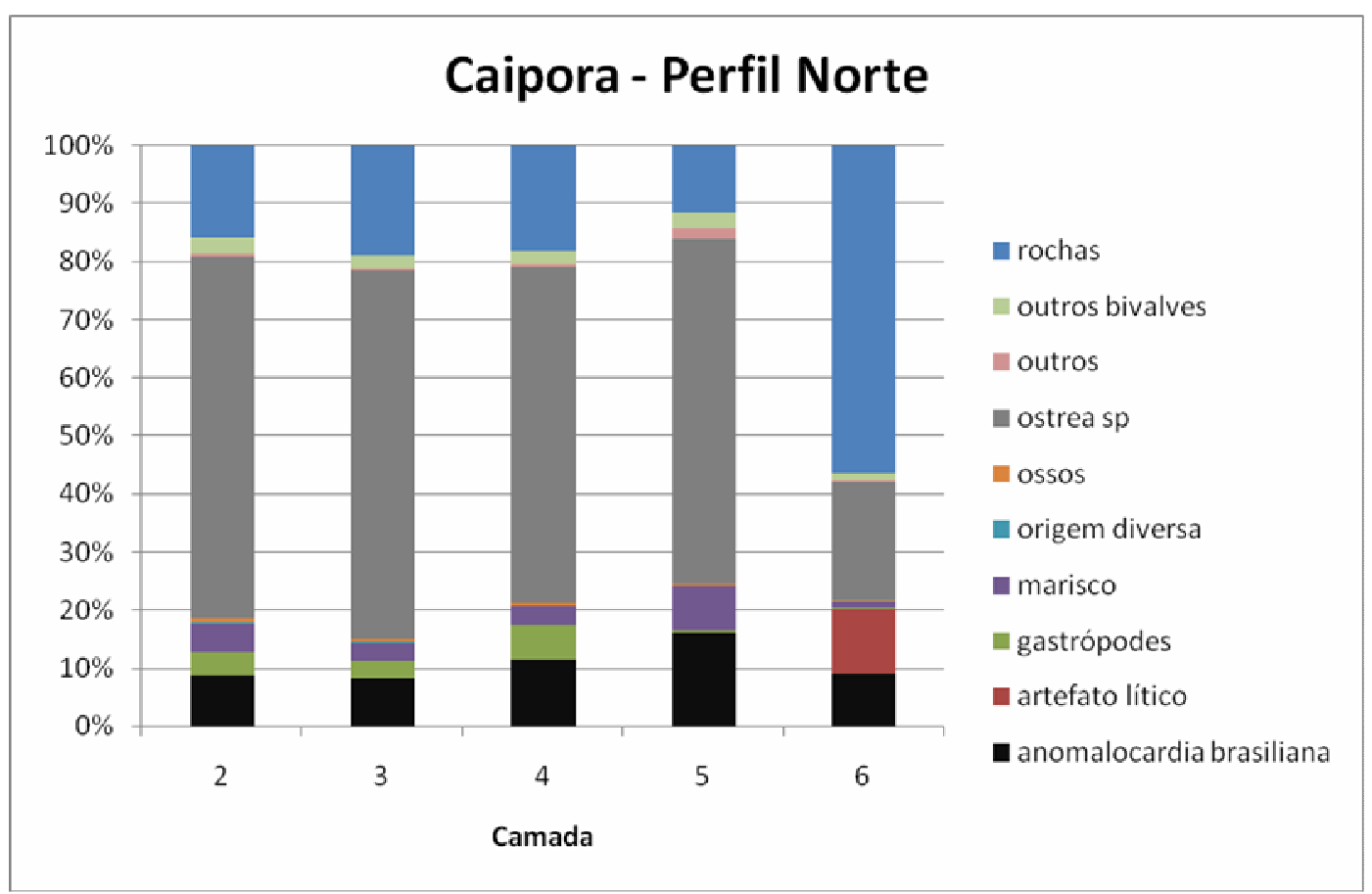

Fig. 37. Sítio Caipora. Perfil N. Componentes da matriz sedimentar. 


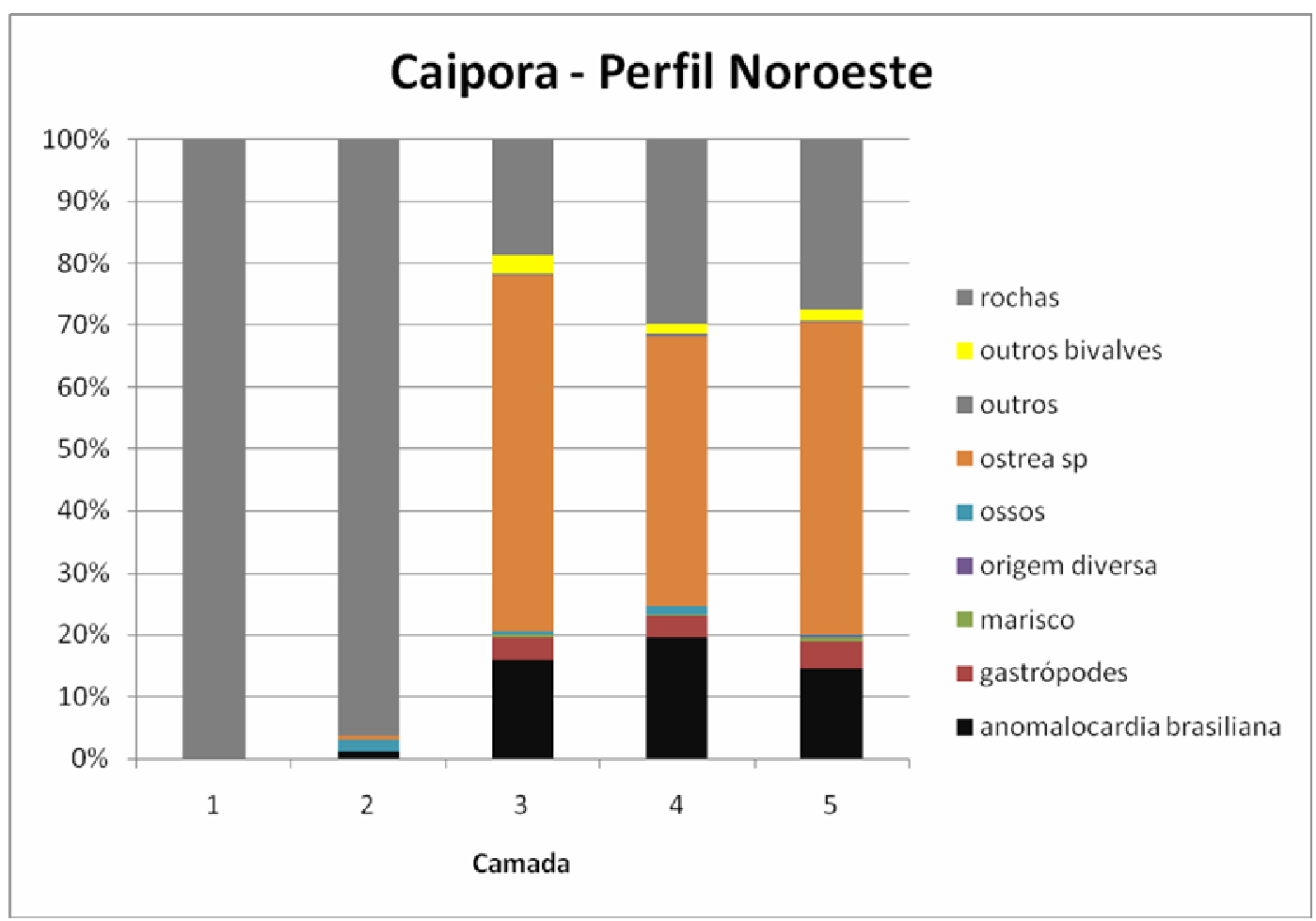

Fig. 38. Sítio Caipora. Perfil NW. Componentes da matriz sedimentar.

Estes dois graficos (Fig 37 e 38) representam as tabelas de composição dos dois perfis abertos para a amostragem e análise do material faunístico do sítio. Para uma melhor visualização dos componentes, eles foram divididos em algumas grandes categorias identificadas na legenda. As categorias marisco, Ostrea sp e Anomalocardia brasiliana estão separadas da categoria outros bivalves, por que a intenção é verificar melhor a expressividade de cada um destes na amostra, a fins de comparação com os outros sítios analisados.

É possível notar a grande quantidade de rochas, principalmente nas camada 1 e 2 , que apresentaram praticamente só este material misurado ao sedimento.

A partir da categoria ossos, realizamos uma análise na qual foram definidos os componentes faunísticos e sua representatividade dentro das amostras zooarqueológicas retiradas do sítio. 


\begin{tabular}{|c|c|c|c|c|c|c|c|c|}
\hline \multirow{2}{*}{ Caipora - Perfil Noroeste } & \multicolumn{2}{|c|}{ Camada 2} & \multicolumn{2}{|c|}{ Camada 3} & \multicolumn{2}{|c|}{ Camada 4} & \multicolumn{2}{|c|}{ Camada 5} \\
\hline & Fragmentos & $(\%)$ & Fragmentos & $(\%)$ & Fragmentos & $(\%)$ & Fragmentos & $(\%)$ \\
\hline dentário sargo & . & . & . & & 1 & $2 \%$ & $\cdot$ & . \\
\hline dente tubarão & . & . & 2 & $2 \%$ & . & . & . & . \\
\hline dentes miraguaia & . & . & . & . & 1 & $2 \%$ & . & \\
\hline fragmentos ossos cranias & 6 & $60 \%$ & 30 & $31 \%$ & 21 & $42 \%$ & 5 & $19 \%$ \\
\hline otolitos bagre & . & . & . & & 2 & $4 \%$ & . & . \\
\hline otólitos corvina & . & . & 1 & $1 \%$ & 1 & $2 \%$ & 2 & $8 \%$ \\
\hline otólitos pescada & . & . & . & . & . & . & 1 & $4 \%$ \\
\hline placa dentaria corvina & 1 & $10 \%$ & . & . & . & & . & . \\
\hline pré-maxilar sargo & . & . & 1 & $1 \%$ & . & . & . & . \\
\hline raio de nadadeira & 1 & $10 \%$ & 2 & $2 \%$ & 2 & $4 \%$ & . & . \\
\hline raio de nadadeira bagre & . & . & . & 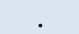 & 1 & $2 \%$ & . & \\
\hline vertebras condrícteos & . & . & 5 & $5 \%$ & 1 & $2 \%$ & 12 & $46 \%$ \\
\hline vertebras de peixe & 2 & $20 \%$ & 56 & $58 \%$ & 20 & $40 \%$ & 6 & $23 \%$ \\
\hline
\end{tabular}

Tabela 7. Sítio Caipora. Perfil NW. Componentes faunísticos da categoria ossos.

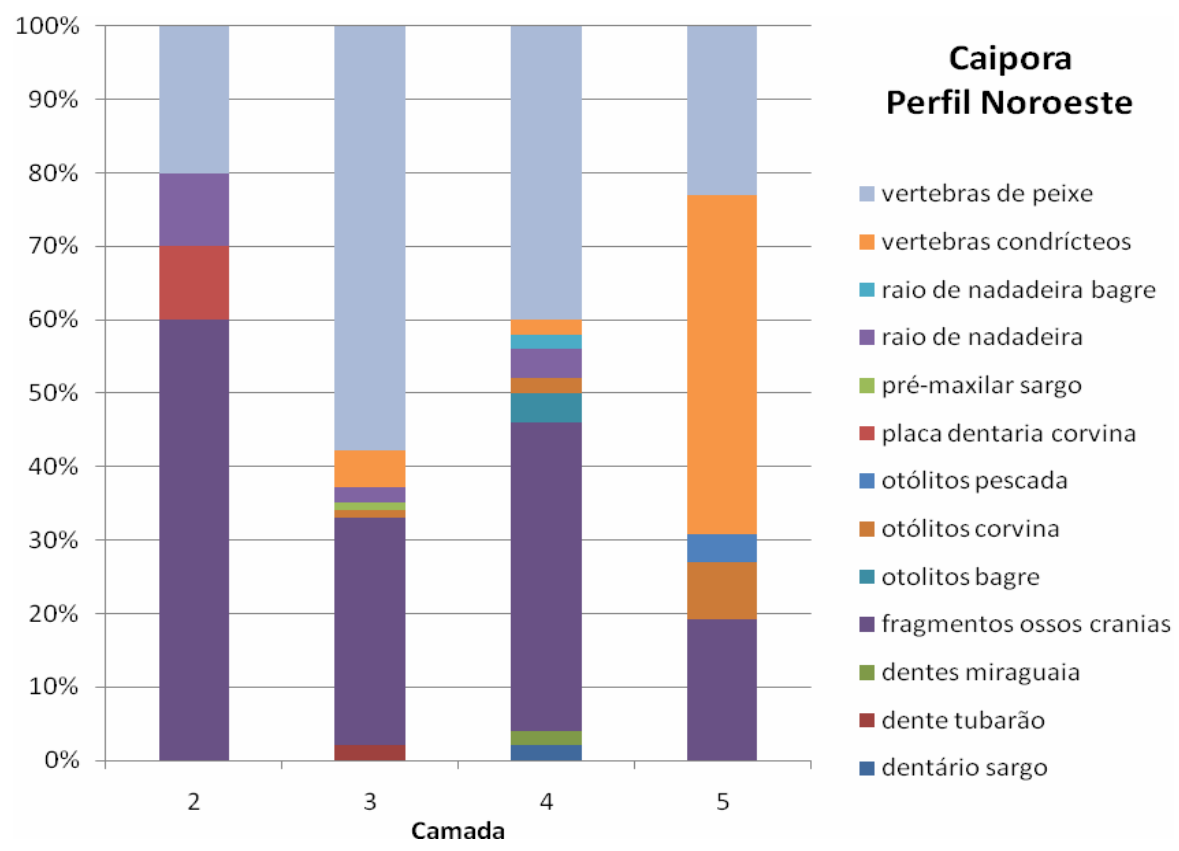

Fig.39. Sítio Caipora. Perfil NW. Componentes faunísticos da categoria ossos. 


\begin{tabular}{|c|c|c|c|c|c|c|c|c|c|c|}
\hline \multirow{2}{*}{ Caipora Perfil Norte } & \multicolumn{2}{|c|}{2} & \multicolumn{2}{|c|}{3} & \multicolumn{2}{|c|}{4} & \multicolumn{2}{|c|}{5} & \multicolumn{2}{|c|}{6} \\
\hline & Frags & $(\%)$ & Frags & $(\%)$ & Frags & $(\%)$ & Frags & $(\%)$ & Frags & $(\%)$ \\
\hline dentário sargo & . & . & . & . & . & . & & . & 1 & $3 \%$ \\
\hline dente tubarão & . & $\cdot$ & 1 & $1 \%$ & . & . & $\cdot$ & . & . & . \\
\hline dentes miraguaia & . & & . & . & 1 & $1 \%$ & & . & . & . \\
\hline fragmentos ossos cranias & 54 & $48 \%$ & 62 & $58 \%$ & 26 & $32 \%$ & 5 & $33 \%$ & . & . \\
\hline garra carangueijo & 1 & $1 \%$ & . & . & . & . & . & . & . & . \\
\hline osso longo (tibia) roedor & . & . & 1 & $1 \%$ & . & . & . & . & . & . \\
\hline otolitos bagre & 1 & $1 \%$ & . & r & 2 & $2 \%$ & . & . & 2 & $6 \%$ \\
\hline otólitos corvina & . & . & 1 & $1 \%$ & 1 & $1 \%$ & 2 & $13 \%$ & 2 & $6 \%$ \\
\hline otólitos pescada & 1 & $1 \%$ & . & . & . & . & 1 & $7 \%$ & . & $0 \%$ \\
\hline placa dentaria corvina & . & . & . & . & 1 & $1 \%$ & . & . & 1 & $3 \%$ \\
\hline placa dentaria raia & 1 & $1 \%$ & . & . & . & . & . & . & 1 & $3 \%$ \\
\hline raio de nadadeira & 8 & $7 \%$ & 6 & $6 \%$ & 3 & $4 \%$ & 1 & $7 \%$ & 7 & $22 \%$ \\
\hline raio de nadadeira bagre & . & & 1 & $1 \%$ & . & . & . & . & . & . \\
\hline vertebras condrícteos & 1 & $1 \%$ & 3 & $3 \%$ & . & . & . & . & . & . \\
\hline vertebras de peixe & 45 & $40 \%$ & 31 & $29 \%$ & 47 & $58 \%$ & 6 & $40 \%$ & 18 & $56 \%$ \\
\hline
\end{tabular}

Tabela 8. Sítio Caipora. Perfil N. Componentes faunísticos da categoria ossos.

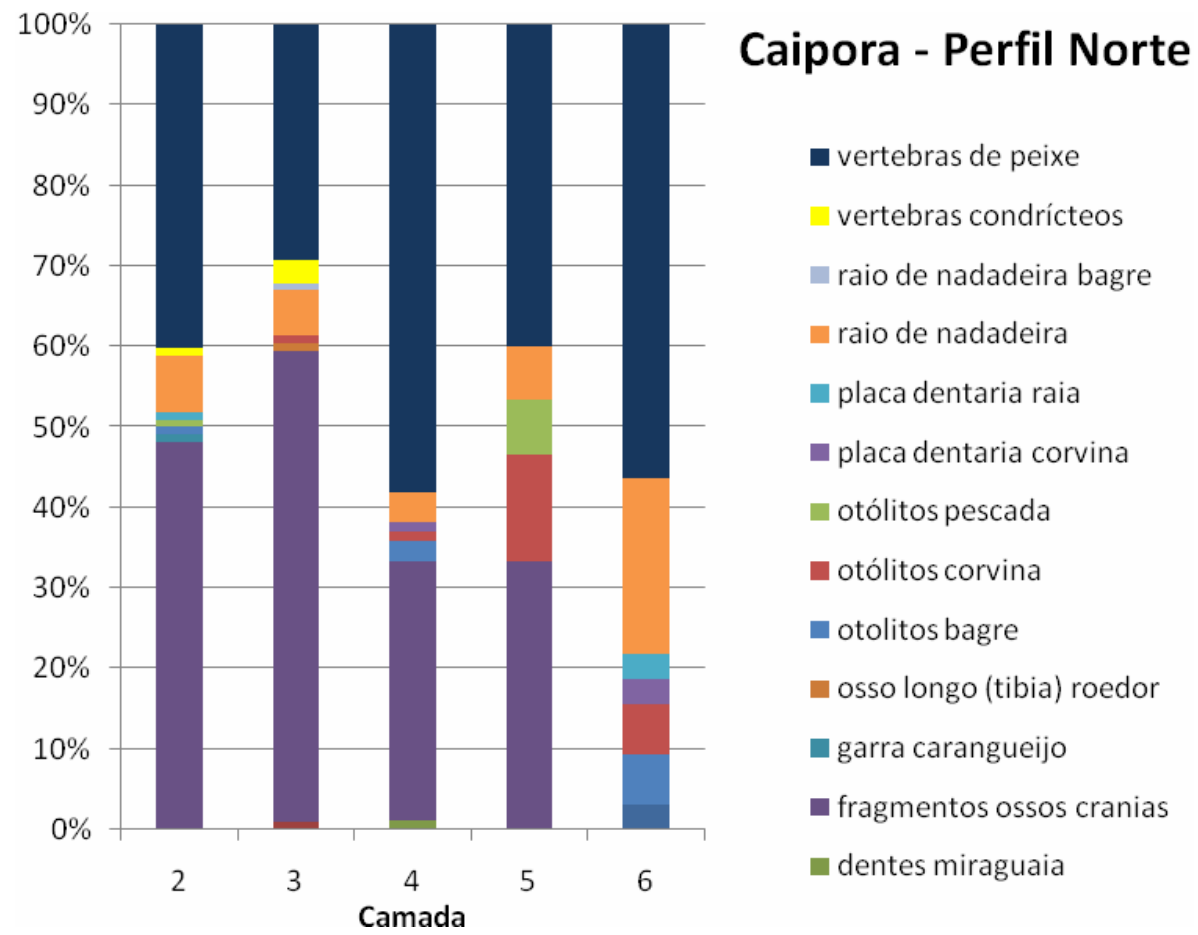

Fig.40. Sítio Caipora. Perfil N. Componentes faunísticos da categoria ossos. 
Analisando as tabelas e graficos pudemos verificar que, com exceção de apenas um fragmento de roedor, todos os outros fragmentos encontrados no sítio Caipora são provenientes dos recursos marinhos e lagunares. Os peixes consumidos podem ser caracterizados como peixes de agua salgada e salobra.

Os graficos abaixo apresentam os valores médios dos comprimentos e largura das valvas e das charneiras de uma subamostra de ostras para a avaliação se ocorreu ou não uma diminuição no tamanho destas.

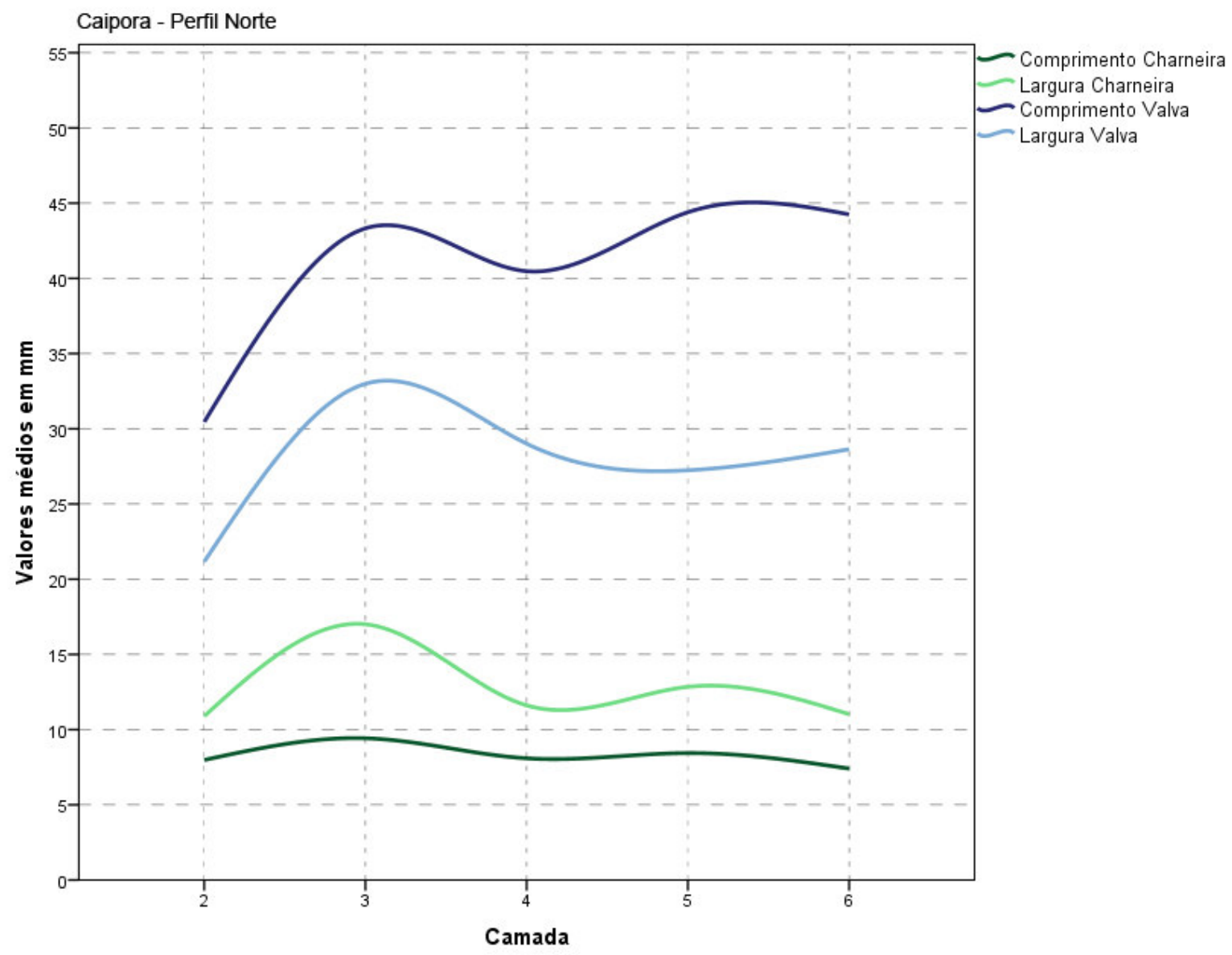

Fig. 41. Sítio Caipora. Perfil N. Dimensões das valvas e charneiras de Ostrea sp. 


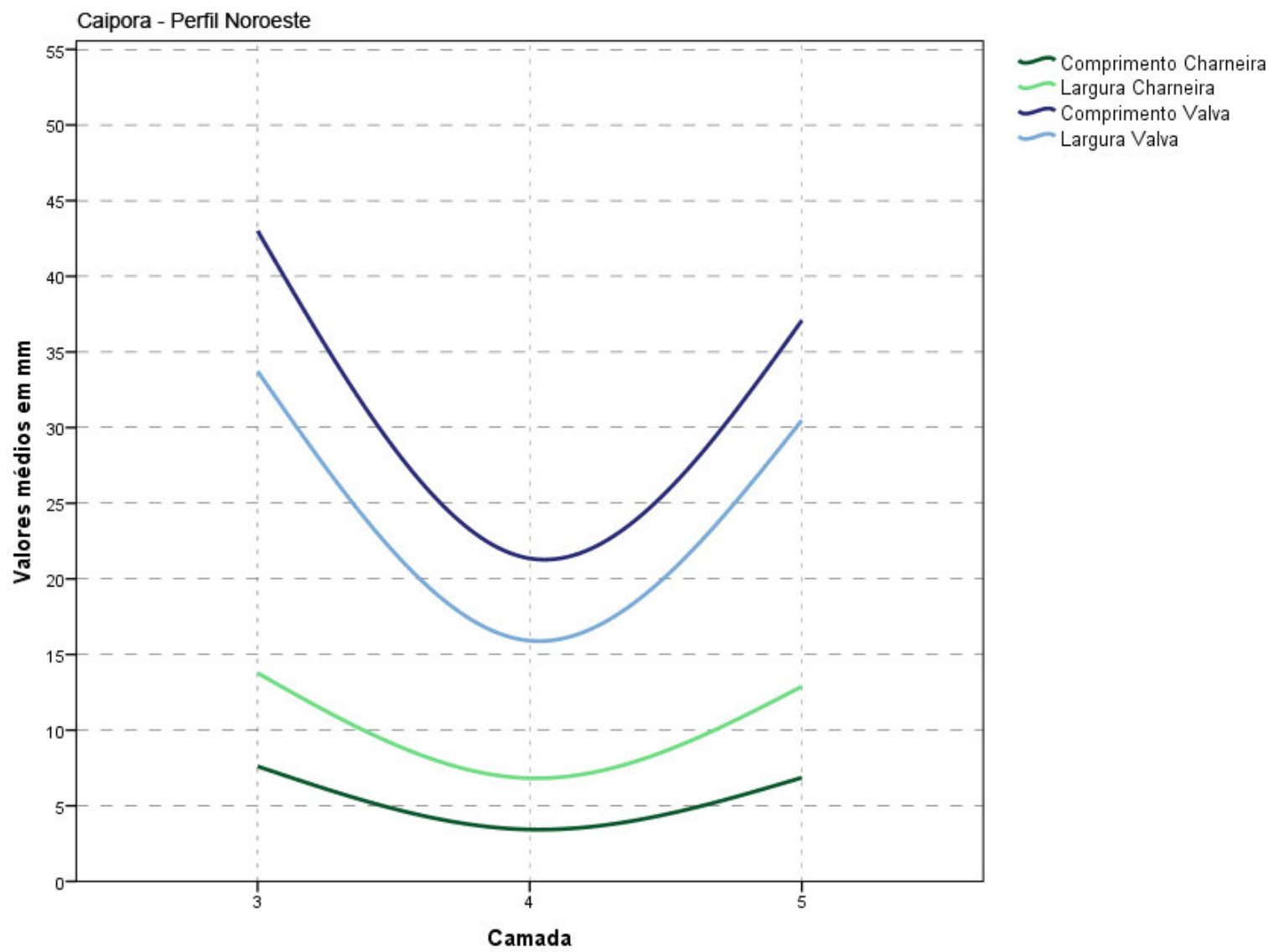

Fig. 42. Sítio Caipora. Perfil NW. Dimensões das valvas e charneiras de Ostrea sp.

Como é possível observar no gráfico, no perfil Norte, observamos uma queda das dimensões das valvas e charneiras na camada 2 (topo), enquanto as outras camadas apresentaram relativamente o mesmo tamanho.

Em relação ao perfil NW, o tamanho das ostras se manteve relativamente parecido, sendo que apenas a camada 4 apresentou uma redução mais significativa em suas dimensões, para logo em seguida aumentar novamente seu tamanho. 


\subsection{O sítio Lageado}

Este sítio (UTM: 22J 0688352/6839863) de pequenas dimensões sofreu um impacto recente devido as ações do proprietário que tentou aplainar o terreno para a construção de uma casa no local. No entanto, uma equipe da UNISUL foi chamada quando diversos sepultamentos foram encontrados pelo morador, que após as explicações desta equipe, permitiu o acesso de pesquisadores para um estudo no sítio. Como já foi dito, este sítio apresentou uma datação bem recuada (5980 anos cal AP), além de uma indústria lítica muito bonita, inclusive com a presença de um zoólito em forma de pássaro, que o morador afirmou estar ao lado do crânio de um dos esqueletos retirados por ele mesmo.

\section{Lageado}

\begin{tabular}{|c|c|}
\hline Material & Peso Total \% \\
\hline Crepídula sp & $0,375 \%$ \\
\hline Outros & $0,480 \%$ \\
\hline Cyrtopleura sp & $0,484 \%$ \\
\hline Neritina virginea & $0,484 \%$ \\
\hline $\begin{array}{l}\text { gastrópodes (nassarius, } \\
\text { cerithium, pugilina) }\end{array}$ & $0,626 \%$ \\
\hline Macoma sp & $0,730 \%$ \\
\hline Thais haemastoma & $0,982 \%$ \\
\hline marisco & $1,026 \%$ \\
\hline vermetídeo & $1,464 \%$ \\
\hline ossos & $3,056 \%$ \\
\hline Lucina pectinata & $4,186 \%$ \\
\hline Anomalocardia brasiliana & $6,147 \%$ \\
\hline rochas & $26,426 \%$ \\
\hline Ostrea sp & $53,534 \%$ \\
\hline
\end{tabular}

Tabela 9. Sítio Lageado. Porcentagem dos componentes da matriz sedimentar 


\begin{tabular}{|c|c|}
\hline \multicolumn{2}{|c|}{ Lageado } \\
\hline Material & Total (\%) \\
\hline marisco & $1,03 \%$ \\
\hline Lucina pectinata & $1,53 \%$ \\
\hline outros & $1,94 \%$ \\
\hline gastrópodes & $2,09 \%$ \\
\hline ossos & $3,06 \%$ \\
\hline outros bivalves & $4,24 \%$ \\
\hline Anomalocardia brasiliana & $6,15 \%$ \\
\hline rochas & $26,43 \%$ \\
\hline Ostrea sp & $53,53 \%$ \\
\hline
\end{tabular}

Tabela 10. Sítio Lageado. Porcentagem dos componentes da matriz sedimentar

\section{Lageado}

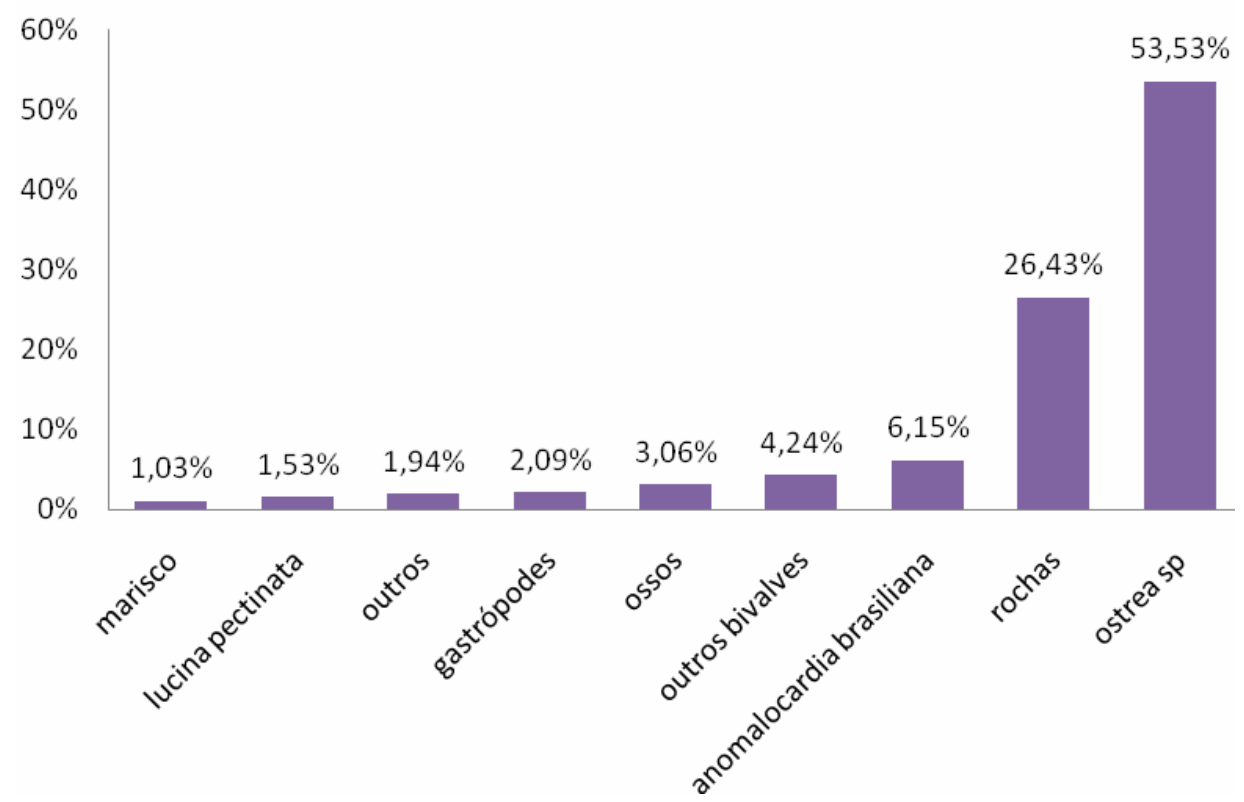

Fig. 43. Sítio Lageado. Porcentagem dos componentes da matriz sedimentar

O sítio Lageado apresenta características muito parecidas com o sítio Caipora, com a ostra como componente principal, seguido pelas rochas e depois pela Anomalocardia. Neste caso, a Ostra aparece com mais de $50 \%$ do total do material construtivo do sítio. Neste sítio 
temos uma pequena quantidade de ossos (3\% do total), mas se compararmos com o sítio Caipora, eles tem uma maior representatividade.

\begin{tabular}{|c|c|c|c|}
\hline \multicolumn{4}{|c|}{ Lageado } \\
\hline P1 - Total $(\mathrm{g})$ & $12.896,00$ & $(\%)$ & $100 \%$ \\
\hline P2 - Total (g) & $2.279,04$ & $(\%)$ & $17,67 \%$ \\
\hline Camada & P1 (g) & P2 (g) & P2 (\%) \\
\hline 1 e 2 & $4.148,00$ & 227,59 & $5,49 \%$ \\
\hline 3 & $3.948,00$ & 150,88 & $3,82 \%$ \\
\hline 4 & $4.800,00$ & 100,95 & $2,10 \%$ \\
\hline
\end{tabular}

Tabela 11. Peso inicial (P1) e peso do material triado (P2), e suas porcentagens relativas a cada camada.

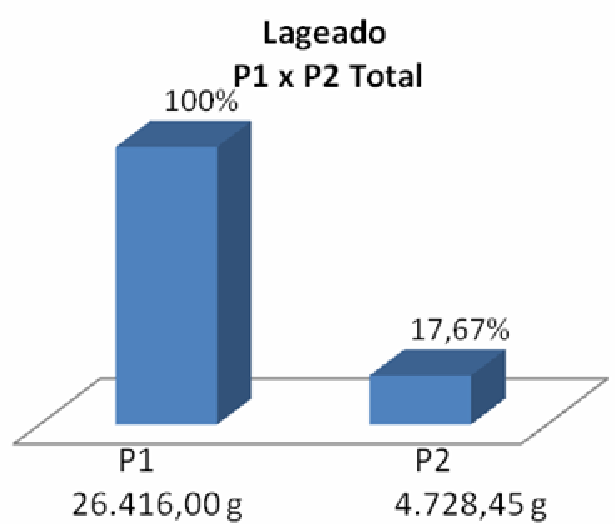

Fig. 44. Sítio Lageado. Porcentagem do Material triado do sítio.

A tabela e gráfico acima (tab 11 e fig. 44) apresentam a relação entre o material coletado e o material triado após a lavagem em laboratório. Novamente temos muito pouco material $(17 \%)$ faunístico em relação a quantidade de sedimento terroso no sítio. Isso pode significar que o material estava muito fragmentado e passou na peneira após a lavagem, no entanto não é o que acontece. O material realmente apresentava-se fragmentado, mas a grande quantidade de sedimento terroso no sítio ficou muito clara já no momento da coleta das amostras. Este sambaqui, assim como o Caipora, foi construído com muito sedimento e relativamente pouca concha, se compararmos com outros sambaquis da região. 


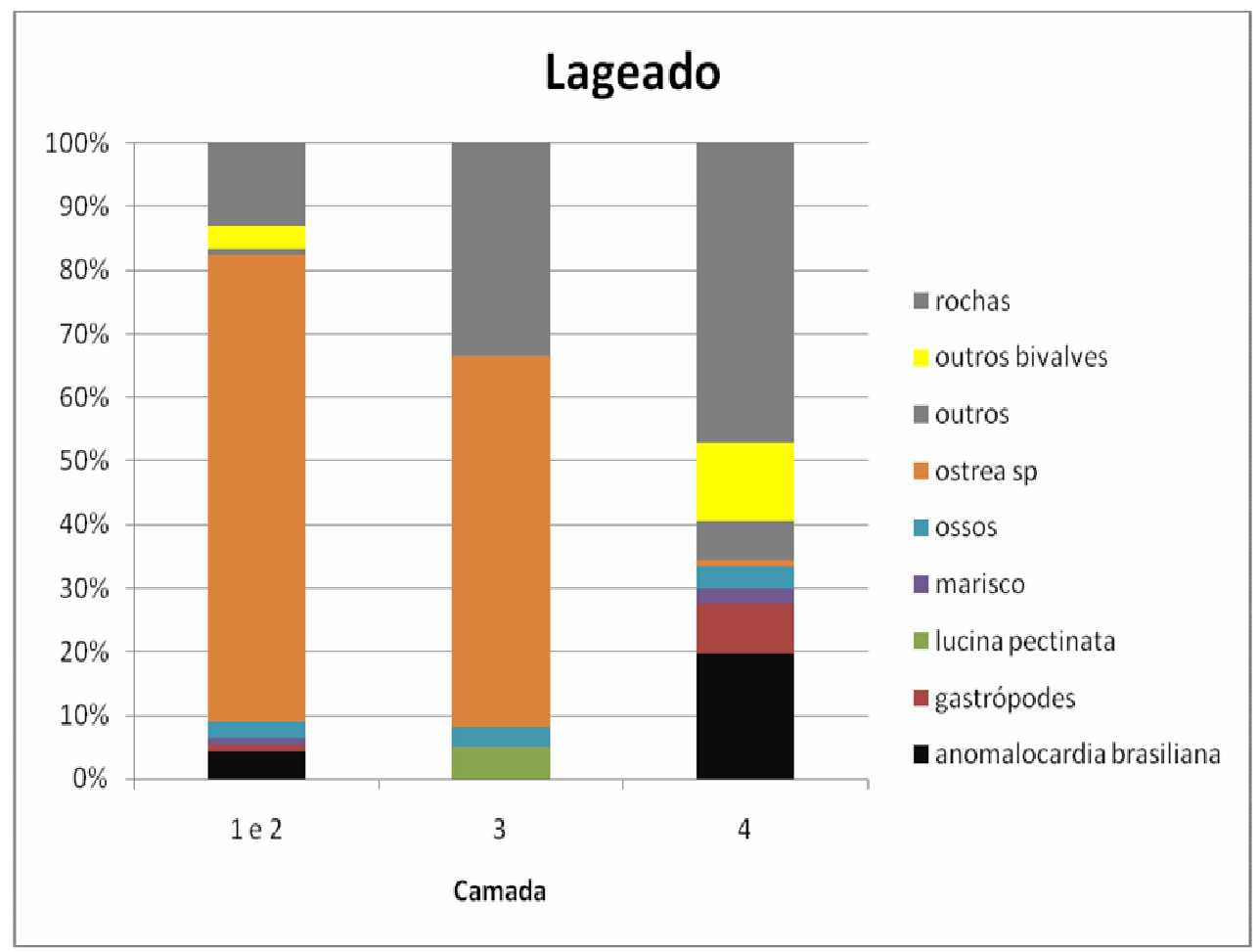

Fig. 45. Sítio Lageado. Componentes da matriz sedimentar do sítio

A grande presença de rochas nas camadas deste sambaqui deve-se a mesma explicação dada para o sambaqui Caipora, no qual as ostras que compõe a matriz do sítio apresentaram muitos fragmentos de granito incrustados nas valvas, o que provavelmente se deveu à retirada destas dos costões rochosos dos arredores do sítio. Além disso, dado que o sambaqui foi construído com muito material terroso, é possível que essa grande quantidade de fragmentos de granito encontrado tenha vindo juntamente com o sedimento utilizado para a elevação do sítio. 


\begin{tabular}{|c|c|c|c|c|c|c|}
\hline \multirow{2}{*}{ Lageado } & \multicolumn{2}{|c|}{ Camada 1 e 2} & \multicolumn{2}{|c|}{ Camada 3} & \multicolumn{2}{|c|}{ Camada 4} \\
\hline & Fragmentos & $(\%)$ & Fragmentos & $(\%)$ & Fragmentos & $(\%)$ \\
\hline dentário sargo & 1 & $1 \%$ & - & $0 \%$ & . & . \\
\hline dentes miraguaia & . & . & . & . & 1 & $2 \%$ \\
\hline fragmentos ossos cranias & 32 & $33 \%$ & 54 & $49 \%$ & 31 & $66 \%$ \\
\hline otólitos pescada & 2 & $2 \%$ & . & $0 \%$ & . & $0 \%$ \\
\hline placa dentaria corvina & 1 & $1 \%$ & 2 & $2 \%$ & . & $0 \%$ \\
\hline placa dentária miraguaia & . & . & . & . & 1 & $2 \%$ \\
\hline pré-maxilar sargo & 1 & $1 \%$ & 1 & $1 \%$ & . & . \\
\hline raio de nadadeira & 5 & $5 \%$ & 3 & $3 \%$ & 1 & $2 \%$ \\
\hline vertebras condrícteos & 7 & $7 \%$ & . & . & . & . \\
\hline vertebras de peixe & 49 & $50 \%$ & 50 & $45 \%$ & 13 & $28 \%$ \\
\hline
\end{tabular}

Tabela 12. Sítio Lageado. Componentes faunísticos da categoria ossos.

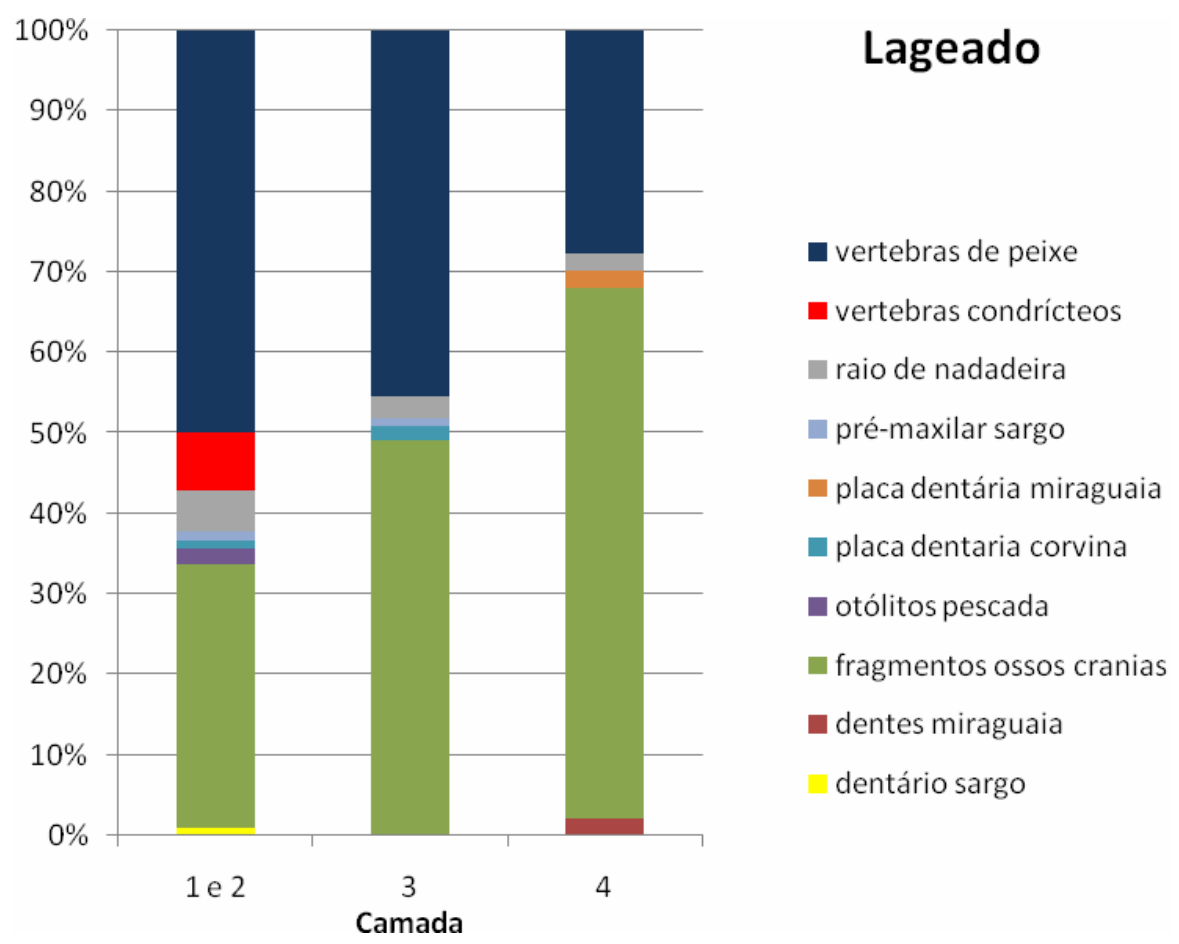

Fig. 46. Sítio Lageado. Componentes faunísticos da categoria ossos. 
A partir da tabela e gráfico acima (tab 12 e fig 46) notamos a total exclusividade de ossos provenientes dos recursos aquaticos da região. Não há sequer um fragmento de osso que possa ser caracterizado como proveniente da mata atlântica das encostas da Serra, que localiza-se bem próxima ao sítio.

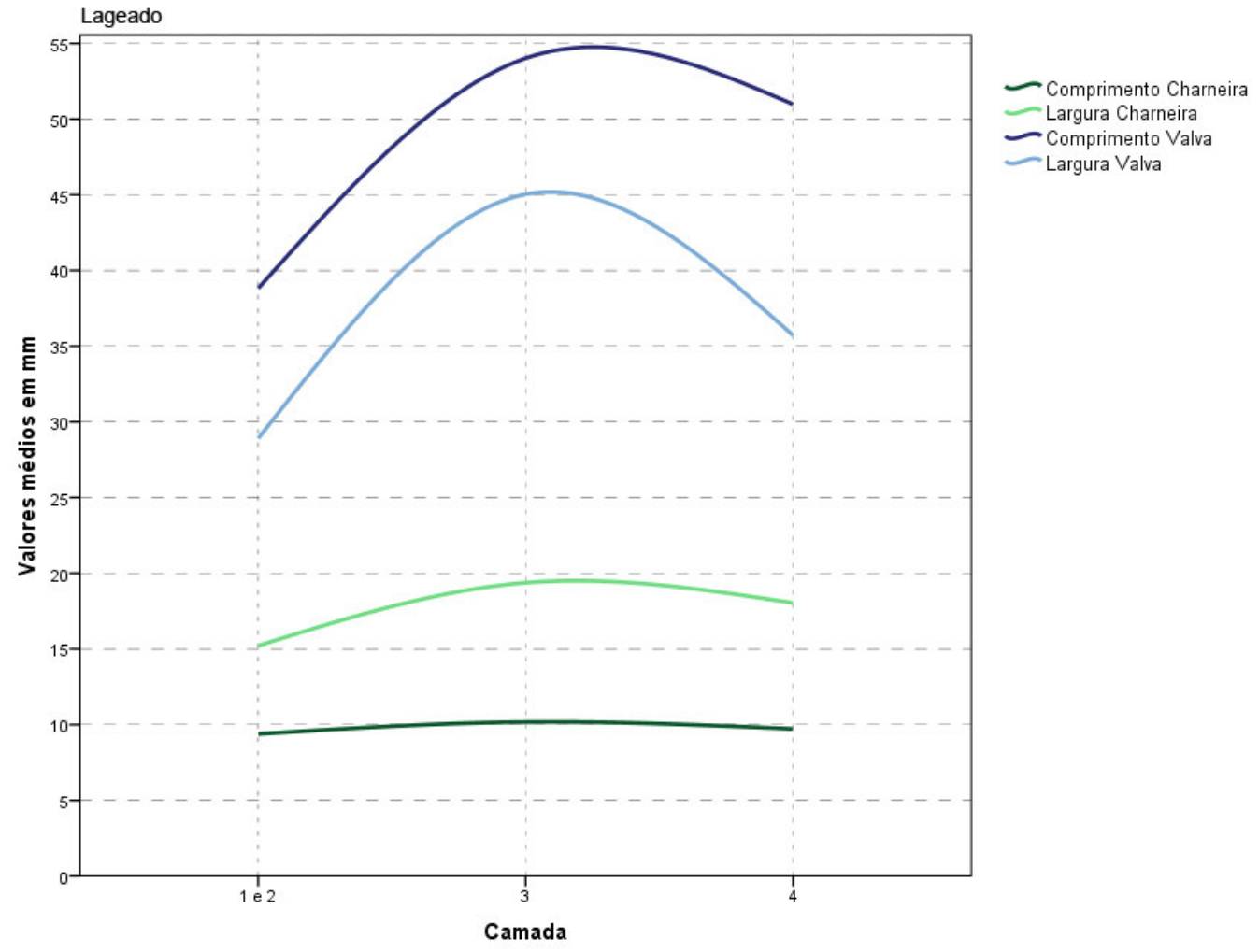

Fig. 47. Sítio Lageado. Dimensões das valvas e charneiras de Ostrea sp.

Em relação ao tamanho das valvas e charneiras amostradas do sítio Lageado, podemos perceber que as dimensões destas apresentaram uma queda mais significativa nas camadas de topo do sítio (1/2). No entanto, a camada 3 do sambaqui era composto por uma densa quantidade de conchas, fato que não ocorre nas camadas $1 / 2$ e 4 , construída com uma menor quantidade de material conchífero. 


\section{$5.3 \mathrm{O}$ sítio Jaboticabeira I}

Jaboticabeira I

\begin{tabular}{|c|c|}
\hline Material & Peso Total \% \\
\hline Dusinia sp & $0,001 \%$ \\
\hline Megalobulimus sp & $0,002 \%$ \\
\hline Argila & $0,003 \%$ \\
\hline Carvão & $0,004 \%$ \\
\hline Cyrtopleura sp & $0,005 \%$ \\
\hline Ocre & $0,005 \%$ \\
\hline Mactra sp & $0,006 \%$ \\
\hline Anadara sp & $0,007 \%$ \\
\hline Gastrópodes terrestes & $0,009 \%$ \\
\hline Queimados & $0,019 \%$ \\
\hline Caramujo terrestre & $0,025 \%$ \\
\hline Macoma sp & $0,033 \%$ \\
\hline Neritina virginea & $0,040 \%$ \\
\hline $\begin{array}{l}\text { Olivela sp e Olivancelaria } \\
\text { sp }\end{array}$ & $0,047 \%$ \\
\hline Donax sp & $0,061 \%$ \\
\hline Outros & $0,132 \%$ \\
\hline Craca & $0,160 \%$ \\
\hline Trachycardium muricatus & $0,171 \%$ \\
\hline Chione sp & $0,173 \%$ \\
\hline Mesodesma sp & $0,228 \%$ \\
\hline Crepídula sp & $0,250 \%$ \\
\hline Lucina pectinata & $0,408 \%$ \\
\hline $\begin{array}{l}\text { Gastrópodes (nassarius, } \\
\text { cerithium, pugilina) }\end{array}$ & $0,438 \%$ \\
\hline Rochas & $0,723 \%$ \\
\hline Ossos & $1,413 \%$ \\
\hline Marisco & $4,073 \%$ \\
\hline Thais haemastoma & $5,242 \%$ \\
\hline Ostrea sp & $19,612 \%$ \\
\hline Anomalocardia brasiliana & $66,708 \%$ \\
\hline
\end{tabular}

Tabela 13. Sítio Jab. I. Componentes da matriz sedimentar do sítio 


\begin{tabular}{|l|c|}
\hline \multicolumn{2}{|c|}{ Jabuticabeira I } \\
\hline \multicolumn{1}{|c|}{ Material } & Total (\%) \\
\hline origem diversa & $0,01 \%$ \\
\hline outros & $0,31 \%$ \\
\hline rochas & $0,72 \%$ \\
\hline outros bivalves & $1,37 \%$ \\
\hline ossos & $1,41 \%$ \\
\hline marisco & $4,07 \%$ \\
\hline gastrópodes & $5,78 \%$ \\
\hline Ostrea sp & $19,61 \%$ \\
\hline Anomalocardia brasiliana & $66,71 \%$ \\
\hline
\end{tabular}

Tabela 14. Sítio Jab. I. Componentes da matriz sedimentar do sítio

\section{Jabuticabeira I}

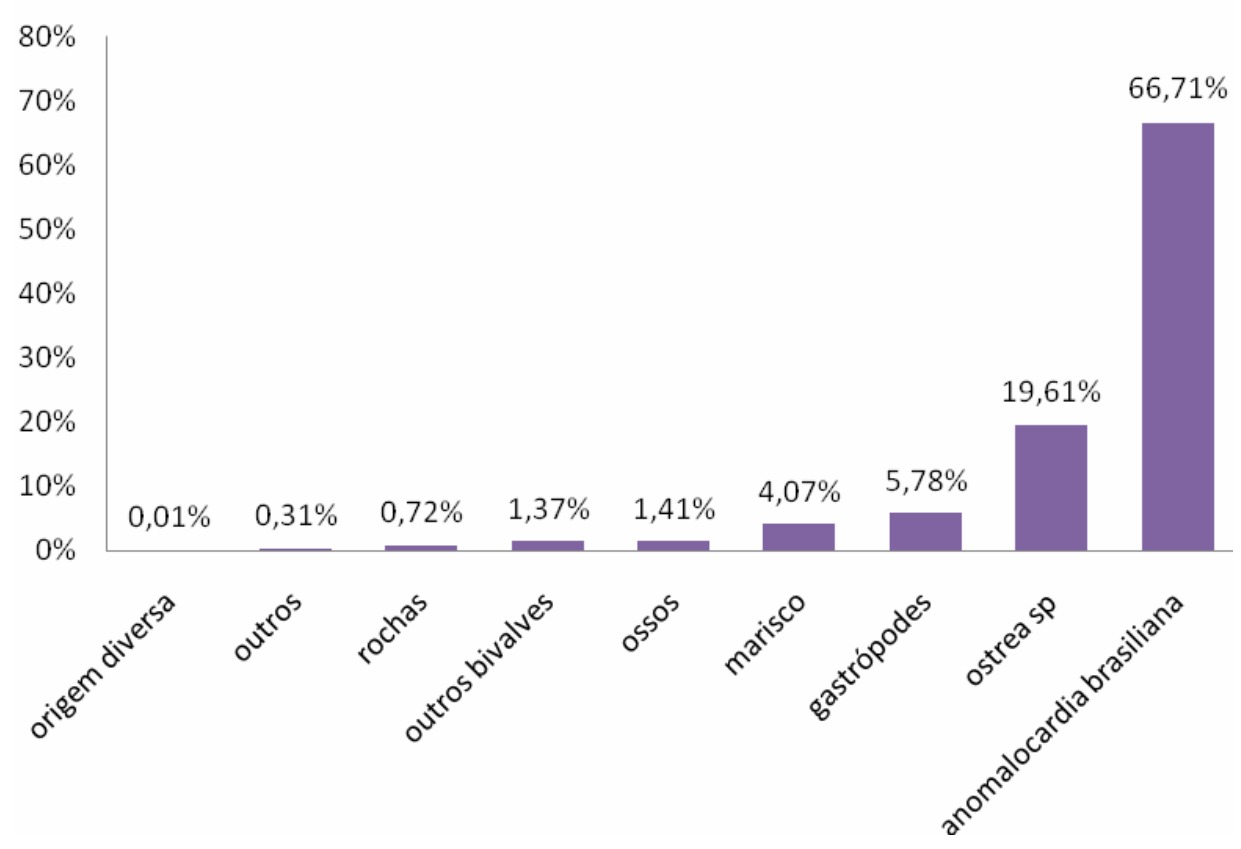

Fig. 48. Sítio Jab. I. Componentes da matriz sedimentar do sítio

Estas duas tabelas e gráfico apresentam os elementos principais que compõem as camadas estratigráficas do sítio Jaboticabeira I. Como podemos ver, a presença massiva de conchas de Anomalocardia brasiliana é evidente, tornando-a a matriz conchífera do sítio, seguido das ostras, depois gastrópodes e mariscos. 


\begin{tabular}{|c|c|c|c|}
\hline \multicolumn{4}{|c|}{ Jaboticabeira I } \\
\hline P1 - Total (g) & $125.032,00$ & $(\%)$ & $100,00 \%$ \\
\hline P2 - Total (g) & $41.107,48$ & $(\%)$ & $32,88 \%$ \\
\hline Camada & $\mathrm{P} 1$ (g) & $\mathrm{P} 2(\mathrm{~g})$ & P2 (\%) \\
\hline 1 & $5.636,00$ & 875,50 & $15,53 \%$ \\
\hline 2 & $5.630,00$ & $1.947,57$ & $34,59 \%$ \\
\hline 3 & $5.176,00$ & $2.377,45$ & $45,93 \%$ \\
\hline 4 & $5.798,00$ & $1.758,90$ & $30,34 \%$ \\
\hline 5 & $5.818,00$ & $3.339,54$ & $57,40 \%$ \\
\hline 6 & $6.208,00$ & $3.067,57$ & $49,41 \%$ \\
\hline 7 & $5.414,00$ & $2.964,20$ & $54,75 \%$ \\
\hline 8 & $5.514,00$ & $2.726,19$ & $49,44 \%$ \\
\hline 9 & $5.264,00$ & $1.490,24$ & $28,31 \%$ \\
\hline 10 & $5.560,00$ & $1.975,27$ & $35,53 \%$ \\
\hline 11 & $5.342,00$ & $1.530,74$ & $28,65 \%$ \\
\hline 12 & $5.580,00$ & $1.533,25$ & $27,48 \%$ \\
\hline 13 & $5.636,00$ & $2.005,79$ & $35,59 \%$ \\
\hline 14 & $5.300,00$ & $1.776,32$ & $33,52 \%$ \\
\hline 15 & $5.206,00$ & 790,93 & $15,19 \%$ \\
\hline 16 & $4.504,00$ & $2.607,53$ & $57,89 \%$ \\
\hline 17 & $4.576,00$ & 927,15 & $20,26 \%$ \\
\hline 18 & $4.374,00$ & $1.898,42$ & $43,40 \%$ \\
\hline 19 & $5.376,00$ & $1.232,09$ & $22,92 \%$ \\
\hline 20 & $3.716,00$ & 775,74 & $20,88 \%$ \\
\hline 21 & $4.612,00$ & 903,87 & $19,60 \%$ \\
\hline 22 & $5.618,00$ & 609,50 & $10,85 \%$ \\
\hline 23 & $4.496,00$ & $1.297,78$ & $28,87 \%$ \\
\hline 24 & $4.678,00$ & 695,94 & $14,88 \%$ \\
\hline
\end{tabular}

Tabela 15.Jab I. Peso inicial (P1) e peso do material triado $(\mathrm{P} 2)$, e suas porcentagens relativas a cada camada 


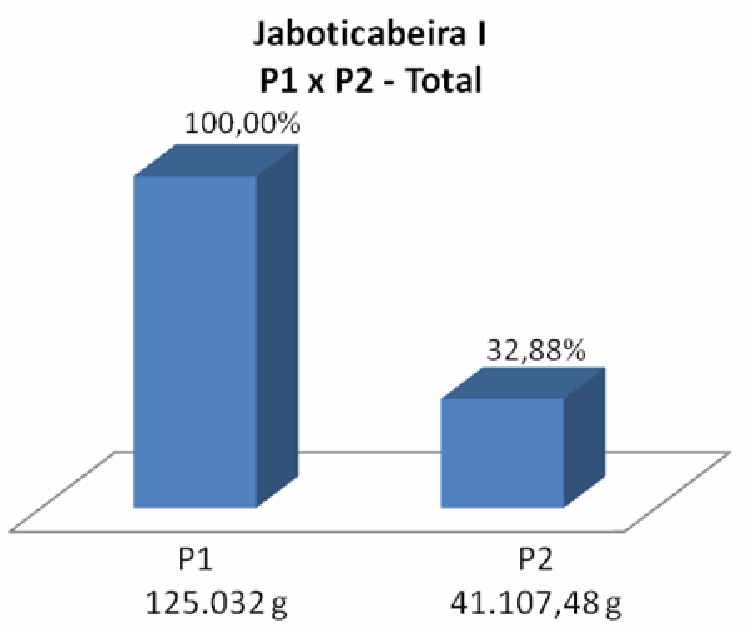

Fig. 49. Porcentagem do Material triado do sítio.

A tabela acima nos mostra a porcentagem triada das amostras por camada, e consequentemente define o grau de fragmentação do material de cada uma delas. O gráfico apresenta a porcentagem triada do sítio como um todo. Nas camadas 15, 22 e 24, o grau de fragmentação é muito alto, o que pode ser explicado devido a grande presença de conchas de mariscos, muito frágeis e de fácil fragmentação. A primeira camada também aparece muito fragmentada, e, assim como nos outros dois sambaquis, ela apresentava muito sedimento e poucas conchas. 


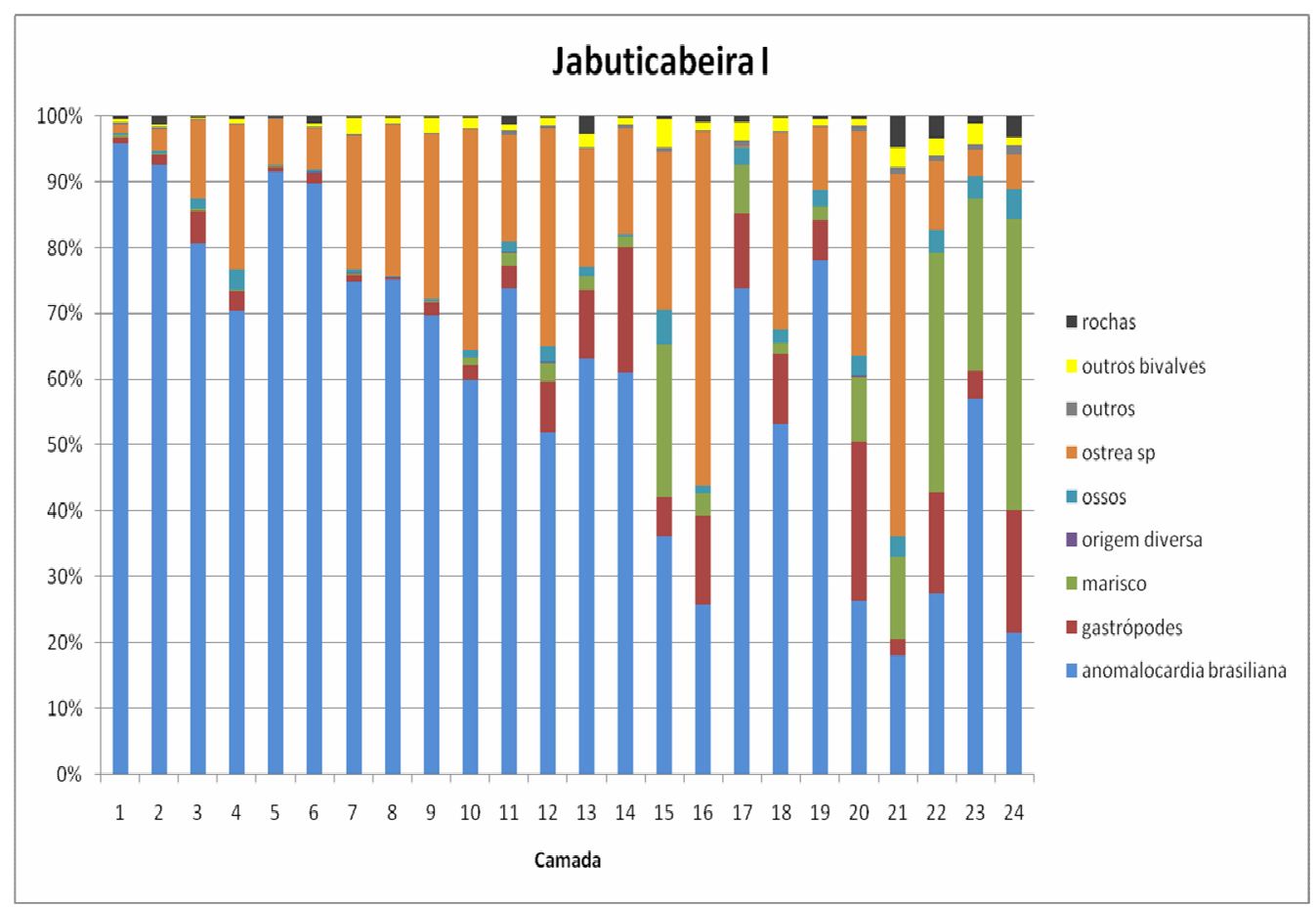

Fig. 50. Jab I. Componentes da matriz sedimentar do sítio por camadas.

Neste gráfico é possível notar a grande quantidade de Anomalocardia em praticamente todas as camadas amostradas do sítio. Apenas as camadas 16 e 21, nos mostra uma diminuição da espécie Anomalocardia em detrimento das ostras, e da 15, ostras e mariscos e as 22 e 24 em detrimento dos mariscos.

A análise dos ossos provenientes do sambaqui Jaboticabeira I está representada nas tabelas abaixo e no gráfico de freqüência de fragmentos e espécies encontradas dentro da categoria ossos da análise faunística geral do sítio.

A partir da análise dos elementos presentes nas amostras pudemos notar que neste caso, algumas espécies, poucas, que não são provenientes dos recursos aquáticos da região aparecem no registro: temos fragmentos de placas de tatu, além de uma vértebra de ofídio nas amostras. No entanto, a grande maioria dos fragmentos ósseos ainda é de peixes da região. 


\begin{tabular}{|c|c|c|c|c|c|c|c|c|c|c|c|c|c|c|c|c|c|c|}
\hline \multirow{2}{*}{ Jabuticabeira I } & \multicolumn{2}{|c|}{ Camada 1} & \multicolumn{2}{|c|}{ Camada 2} & \multicolumn{2}{|c|}{ Camada 3} & \multicolumn{2}{|c|}{ Camada 4} & \multicolumn{2}{|c|}{ Camada 5} & \multicolumn{2}{|c|}{ Camada 6} & \multicolumn{2}{|c|}{ Camada 7} & \multicolumn{2}{|c|}{ Camada 8} & \multicolumn{2}{|c|}{ Camada 9} \\
\hline & Frags & $(\%)$ & Frags & $(\%)$ & Frags & $(\%)$ & Frags & $(\%)$ & Frags & $(\%)$ & Frags & $(\%)$ & Frags & $(\%)$ & Frags & $(\%)$ & Frags & $(\%)$ \\
\hline artefato - biponta & . & . & . & . & . & . & . & . & . & . & . & . & . & . & . & . & . & $0,0 \%$ \\
\hline dentário baiacu & . & . & . & . & . & . & . & . & . & . & . & . & . & . & . & . & . & $0,0 \%$ \\
\hline dentário sargo & . & . & . & . & 1 & $0,4 \%$ & . & . & . & . & . & . & . & . & 1 & $1,6 \%$ & . & $0,0 \%$ \\
\hline dentes miraguaia & . & . & 2 & $5,1 \%$ & 2 & $0,7 \%$ & 4 & $1,5 \%$ & 5 & $9,8 \%$ & 9 & $13,8 \%$ & 4 & $3,9 \%$ & . & . & 5 & $15,2 \%$ \\
\hline esporão de raia & . & . & . & . & . & . & . & . & . & . & . & . & . & . & . & . & . & . \\
\hline $\begin{array}{l}\text { fragmentos ossos } \\
\text { cranias }\end{array}$ & 13 & $46,4 \%$ & 20 & $51,3 \%$ & 150 & $54,0 \%$ & 137 & $51,7 \%$ & 27 & $52,9 \%$ & 33 & $50,8 \%$ & 56 & $54,9 \%$ & 39 & $62,9 \%$ & 13 & $39,4 \%$ \\
\hline garra carangueijo & . & . & . & . & 1 & $0,4 \%$ & . & . & . & . & . & . & . & . & . & . & . & . \\
\hline garra siri & . & . & . & . & . & . & . & . & . & . & . & . & . & . & . & . & . & . \\
\hline otolitos bagre & . & . & . & . & 1 & $0,4 \%$ & 3 & $1,1 \%$ & 1 & $2,0 \%$ & . & $0,0 \%$ & 3 & $2,9 \%$ & 1 & $1,6 \%$ & 1 & $3,0 \%$ \\
\hline otólitos corvina & . & . & 2 & $5,1 \%$ & 26 & $9,4 \%$ & 41 & $15,5 \%$ & 3 & $5,9 \%$ & 3 & $4,6 \%$ & 5 & $4,9 \%$ & 1 & $1,6 \%$ & 4 & $12,1 \%$ \\
\hline otólitos miraguaia & . & . & . & . & . & . & 2 & $0,8 \%$ & . & . & 1 & $1,5 \%$ & 1 & $1,0 \%$ & . &. & 1 & $3,0 \%$ \\
\hline otólitos pescada & . & . & . & . & 1 & $0,4 \%$ & . & . & 1 & $2,0 \%$ & . & $0,0 \%$ & . & . & . & . & . &. \\
\hline p.d. corvina & . & . & . & . & 6 & $2,2 \%$ & . & . & . & . & . & . & . & . & . & . & . & . \\
\hline p.d. F. cocoroca & . & . & . & . & . & . & . & . & . & . & . & . & . & . & . & . & . & $\cdot$ \\
\hline p.d. miraguaia & . & . & . & . & . & . & . & . & . & . & . & . & 3 & $2,9 \%$ & 2 & $3,2 \%$ & 1 & $3,0 \%$ \\
\hline placa dentaria raia & . & . & . & . & 17 & $6,1 \%$ & 3 & $1,1 \%$ & . & . & . & . & 7 & $6,9 \%$ & . & . & . & . \\
\hline placa dentaria sargo & . & . & . & . & . &. & . & . & . & . & . & . & . & . & . & . & . & . \\
\hline placa tartaruga & . & . & . & . & . & . & . & . & . & . & . & . & . & . & . & . & . & . \\
\hline placa tatu & 1 & $3,6 \%$ & . & . & . & . & . & . & . & . & . & . & . & . & . & . & . & . \\
\hline pré-maxilar sargo & . & . & . & . & . & . & . & . & . & . & . & . & . & . & . & . & . & . \\
\hline $\begin{array}{l}\text { pterigióforo anal de } \\
\text { Paru }\end{array}$ & . & . & . & . & . & . & 1 & $0,4 \%$ & . & . & . & . & . & . & . & . & . & . \\
\hline raio de nadadeira & . & . & . & . & 4 & $1,4 \%$ & 6 & $2,3 \%$ & 1 & $2,0 \%$ & 2 & $3,1 \%$ & . & . & 1 & $1,6 \%$ & 1 & $3,0 \%$ \\
\hline $\begin{array}{l}\text { raio de nadadeira } \\
\text { bagre }\end{array}$ & . & . & . & . & . & . & . & 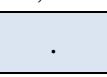 & . & 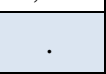 & . & . & . & . & . & . & . & . \\
\hline vertebra ofídio & . & . & . & . & . & . & . & . & . & . & . & . & . & . & . & . & . & . \\
\hline vertebras condrícteos & . & . & . & . & 3 & $1,1 \%$ & 8 & $3,0 \%$ & . & . & . & . & 1 & $1,0 \%$ & . & . & . & . \\
\hline vertebras de peixe & 14 & $50,0 \%$ & 15 & $38,5 \%$ & 66 & $23,7 \%$ & 60 & $22,6 \%$ & 13 & $25,5 \%$ & 17 & $26,2 \%$ & 22 & $21,6 \%$ & 17 & $27,4 \%$ & 7 & $21,2 \%$ \\
\hline
\end{tabular}




\begin{tabular}{|c|c|c|c|c|c|c|c|c|c|c|c|c|c|c|c|c|c|c|}
\hline \multirow{2}{*}{ Jabuticabeira I } & \multicolumn{2}{|c|}{ Camada 10} & \multicolumn{2}{|c|}{ Camada 11} & \multicolumn{2}{|c|}{ Camada 12} & \multicolumn{2}{|c|}{ Camada 13} & \multicolumn{2}{|c|}{ Camada 14} & \multicolumn{2}{|c|}{ Camada 15} & \multicolumn{2}{|c|}{ Camada 16} & \multicolumn{2}{|c|}{ Camada 17} & \multicolumn{2}{|c|}{ Camada 18} \\
\hline & Frags & $(\%)$ & Frags & $(\%)$ & Frags & $(\%)$ & Frags & $(\%)$ & Frags & $(\%)$ & Frags & $(\%)$ & Frags & $(\%)$ & Frags & $(\%)$ & Frags & $(\%)$ \\
\hline artefato - biponta & . & . & . & . & . & . & . & . & . & . & . & . & . & . & . & . & . & . \\
\hline dentário baiacu & 1 & $0,7 \%$ & . & . & 1 & $0,4 \%$ & . & . & 2 & $3,8 \%$ & . & . & . & . & . & . & . & . \\
\hline dentário sargo & . & . & . & . & . & . & 2 & $1,1 \%$ & . & . & . & . & . & . & . & . & . & . \\
\hline dentes miraguaia & 6 & $4,0 \%$ & 2 & $0,6 \%$ & 11 & $4,6 \%$ & 7 & $3,8 \%$ & 1 & $1,9 \%$ & 1 & $0,3 \%$ & 10 & $3,0 \%$ & 4 & $1,2 \%$ & 2 & $0,8 \%$ \\
\hline esporão de raia & . & . & 5 & $1,6 \%$ & 1 & $0,4 \%$ & . & . & . & . & . & . & 2 & $0,6 \%$ & . & . & . & . \\
\hline fragmentos ossos & 92 & 61,7 & 216 & 69,0 & 152 & 63,1 & 119 & 64,3 & 36 & 67,9 & 232 & 58,7 & 211 & 64,1 & 225 & 68,0 & 148 & 62,4 \\
\hline garra carangueijo & . & . & . & . & . & . & . & . & . & . & . & . & 2 & $0,6 \%$ & . & . & . & . \\
\hline garra siri & . & . & 1 & $0,3 \%$ & . & . & . & . & . & . & 2 & $0,5 \%$ & . & . & . & . & . & . \\
\hline otolitos bagre & . & . & 10 & $3,2 \%$ & . & . & . & . & 1 & $1,9 \%$ & 4 & $1,0 \%$ & 3 & $0,9 \%$ & 2 & $0,6 \%$ & 3 & $1,3 \%$ \\
\hline otólitos corvina & 7 & $4,7 \%$ & 14 & $4,5 \%$ & 8 & $3,3 \%$ & 5 & $2,7 \%$ & 1 & $1,9 \%$ & 2 & $0,5 \%$ & . & . & 3 & $0,9 \%$ & 4 & $1,7 \%$ \\
\hline otólitos miraguaia & . & . & . & . & . & . & . & . & . & . & . & . & . & . & 2 & $0,6 \%$ & 6 & $2,5 \%$ \\
\hline otólitos pescada & 1 & $0,7 \%$ & 1 & $0,3 \%$ & . & . & 2 & $1,1 \%$ & . & . & 4 & $1,0 \%$ & . & . & 1 & $0,3 \%$ & . & . \\
\hline p. d. corvina & 1 & $0,7 \%$ & 2 & $0,6 \%$ & 1 & $0,4 \%$ & 2 & $1,1 \%$ & . & . & 1 & $0,3 \%$ & . & . & 1 & $0,3 \%$ & 1 & $0,4 \%$ \\
\hline p. d. F. cocoroca & . & . & . & . & . & . & . & . & . & . & . & . & . & . & . & . & . & . \\
\hline p.d. miraguaia & 1 & $0,7 \%$ & . & . & 1 & $0,4 \%$ & 3 & $1,6 \%$ & 1 & $1,9 \%$ & . & . & 10 & $3,0 \%$ & . & $0,0 \%$ & 2 & $0,8 \%$ \\
\hline placa dentaria raia & . & . & 1 & $0,3 \%$ & . & . & . & . & . & . & . & . & 3 & $0,9 \%$ & 1 & $0,3 \%$ & . & . \\
\hline placa dentaria sargo & . & . & 1 & $0,3 \%$ & . & . & . & . & 1 & $1,9 \%$ & . & . & . & . & . & . & . & . \\
\hline placa tartaruga & . & . & . & . & . & . & . & . & . & . & . & . & . & . & . & . & . & . \\
\hline placa tatu & . & . & . & . & . & . & . & . & . & . & . & . & . & . & . & . & . & . \\
\hline pré-maxilar sargo & . & . & . & . & . & . & 1 & $0,5 \%$ & . & . & . & . & . & . & . & . & . & . \\
\hline $\begin{array}{l}\text { pterigióforo anal de } \\
\text { Paru }\end{array}$ & . & . & . & . & . & . & . & . & . & . & . & . & . & . & . & . & . & . \\
\hline raio de nad. & 10 & $6,7 \%$ & 16 & $5,1 \%$ & 15 & $6,2 \%$ & 17 & $9,2 \%$ & 1 & $1,9 \%$ & 28 & $7,1 \%$ & 18 & $5,5 \%$ & 20 & $6,0 \%$ & 24 & 10,1 \\
\hline raio de nad. bagre & . & . & . & . & . & . & . & . & . & . & 1 & $0,3 \%$ & . & . & . & . & . & . \\
\hline vértebra ofídio & . & . & . & . & . & . & . & . & . & . & . & . & 1 & $0,3 \%$ & . & . & . & . \\
\hline Vért. condrícteos & . & . & 4 & $1,3 \%$ & . & . & . & . & . & . & 18 & $4,6 \%$ & 9 & $2,7 \%$ & 4 & $1,2 \%$ & . & . \\
\hline vértebras de peixe & 30 & 20,1 & 40 & 12,8 & 50 & 20,7 & 27 & 14,6 & 9 & 17,0 & 102 & 25,8 & 60 & 18,2 & 68 & 20,5 & 47 & 19,8 \\
\hline
\end{tabular}




\begin{tabular}{|c|c|c|c|c|c|c|c|c|c|c|c|c|}
\hline \multirow{2}{*}{ Jabuticabeira I } & \multicolumn{2}{|c|}{ Camada 19} & \multicolumn{2}{|c|}{ Camada 20} & \multicolumn{2}{|c|}{ Camada 21} & \multicolumn{2}{|c|}{ Camada 22} & \multicolumn{2}{|c|}{ Camada 23} & \multicolumn{2}{|c|}{ Camada 24} \\
\hline & Frags & $(\%)$ & Frags & $(\%)$ & Frags & $(\%)$ & Frags & $(\%)$ & Frags & $(\%)$ & Frags & $(\%)$ \\
\hline artefato - biponta &. & . &. & . &. & $\cdot$ &. & . &. & . & 1 & $0,2 \%$ \\
\hline dentário baiacu & . & . & . & . & . & . & . & . & . & . & . & . \\
\hline dentário sargo & . & . & . & . & . & . & . & . & . & . & . & . \\
\hline dentes miraguaia & 5 & $2,0 \%$ & 2 & $0,9 \%$ & 2 & $0,6 \%$ & 5 & $1,8 \%$ & . & . & . & . \\
\hline esporão de raia & . & . & . & . & . & . & 1 & $0,4 \%$ & . & . & . & . \\
\hline fragmentos ossos cranias & 156 & $61,7 \%$ & 112 & $52,8 \%$ & 192 & $56,1 \%$ & 180 & $65,7 \%$ & 299 & $65,3 \%$ & 282 & $66,8 \%$ \\
\hline garra carangueijo & . &. & 2 & $0,9 \%$ & 1 & $0,3 \%$ & 1 & $0,4 \%$ & . & . & . & . \\
\hline garra siri & 1 & $0,4 \%$ & 1 & $0,5 \%$ & 3 & $0,9 \%$ & 2 & $0,7 \%$ & 7 & $1,5 \%$ & 4 & $0,9 \%$ \\
\hline otolitos bagre & . & $\cdot$ & 4 & $1,9 \%$ & 3 & $0,9 \%$ & 6 & $2,2 \%$ & 3 & $0,7 \%$ & 2 & $0,5 \%$ \\
\hline otólitos corvina & 8 & $3,2 \%$ & 1 & $0,5 \%$ & 2 & $0,6 \%$ & 2 & $0,7 \%$ & 3 & $0,7 \%$ & 4 & $0,9 \%$ \\
\hline otólitos miraguaia & 4 & $1,6 \%$ & 1 & $0,5 \%$ & . & $\cdot$ & . & $\cdot$ & 1 & $0,2 \%$ & . & . \\
\hline otólitos pescada & . & $0,0 \%$ & 1 & $0,5 \%$ & 1 & $0,3 \%$ & 1 & $0,4 \%$ & 1 & $0,2 \%$ & 1 & $0,2 \%$ \\
\hline placa dentaria corvina & 2 & $0,8 \%$ & . & . & . & . & . & $\cdot$ & 5 & $1,1 \%$ & . & . \\
\hline placa dentária faringeana cocoroca & . & . & . & $\cdot$ & . & . & 1 & $0,4 \%$ & . & $\cdot$ & . & . \\
\hline placa dentária miraguaia & 3 & $1,2 \%$ & 2 & $0,9 \%$ & . & . & 2 & $0,7 \%$ & . & . & 2 & $0,5 \%$ \\
\hline placa dentaria raia & 2 & $0,8 \%$ & . & $\cdot$ & . & . & . & $\cdot$ & . & . & . & . \\
\hline placa dentaria sargo & . & . & . & . & . & . & . & . & . & . & . & . \\
\hline placa tartaruga & . & . & . & . & . & . & . & . & 3 & $0,7 \%$ & . & . \\
\hline placa tatu & . & . & . & . & . & . & . & . & . &. & 1 & $0,2 \%$ \\
\hline pré-maxilar sargo & . & . & . & . & . & . & . & . & . & . & 1 & $0,2 \%$ \\
\hline pterigióforo anal de Paru & . & . & . & . & . & . & . & . & . & . & . & . \\
\hline raio de nadadeira & 17 & $6,7 \%$ & 10 & $4,7 \%$ & 16 & $4,7 \%$ & 21 & $7,7 \%$ & 26 & $5,7 \%$ & 39 & $9,2 \%$ \\
\hline raio de nadadeira bagre & . & . & . & . & . & . & . & . & 2 & $0,4 \%$ & . & . \\
\hline vertebra ofídio & . & . & . & . & . & . & . & . & . &. & . & . \\
\hline vertebras condrícteos & 3 & $1,2 \%$ & . & . & . & . & . & . & 2 & $0,4 \%$ & . & . \\
\hline vertebras de peixe & 52 & $20,6 \%$ & 76 & $35,8 \%$ & 122 & $35,7 \%$ & 52 & $19,0 \%$ & 106 & $23,1 \%$ & 85 & $20,1 \%$ \\
\hline
\end{tabular}

Tabela 16. Jab I. Componentes faunísticos da categoria ossos 


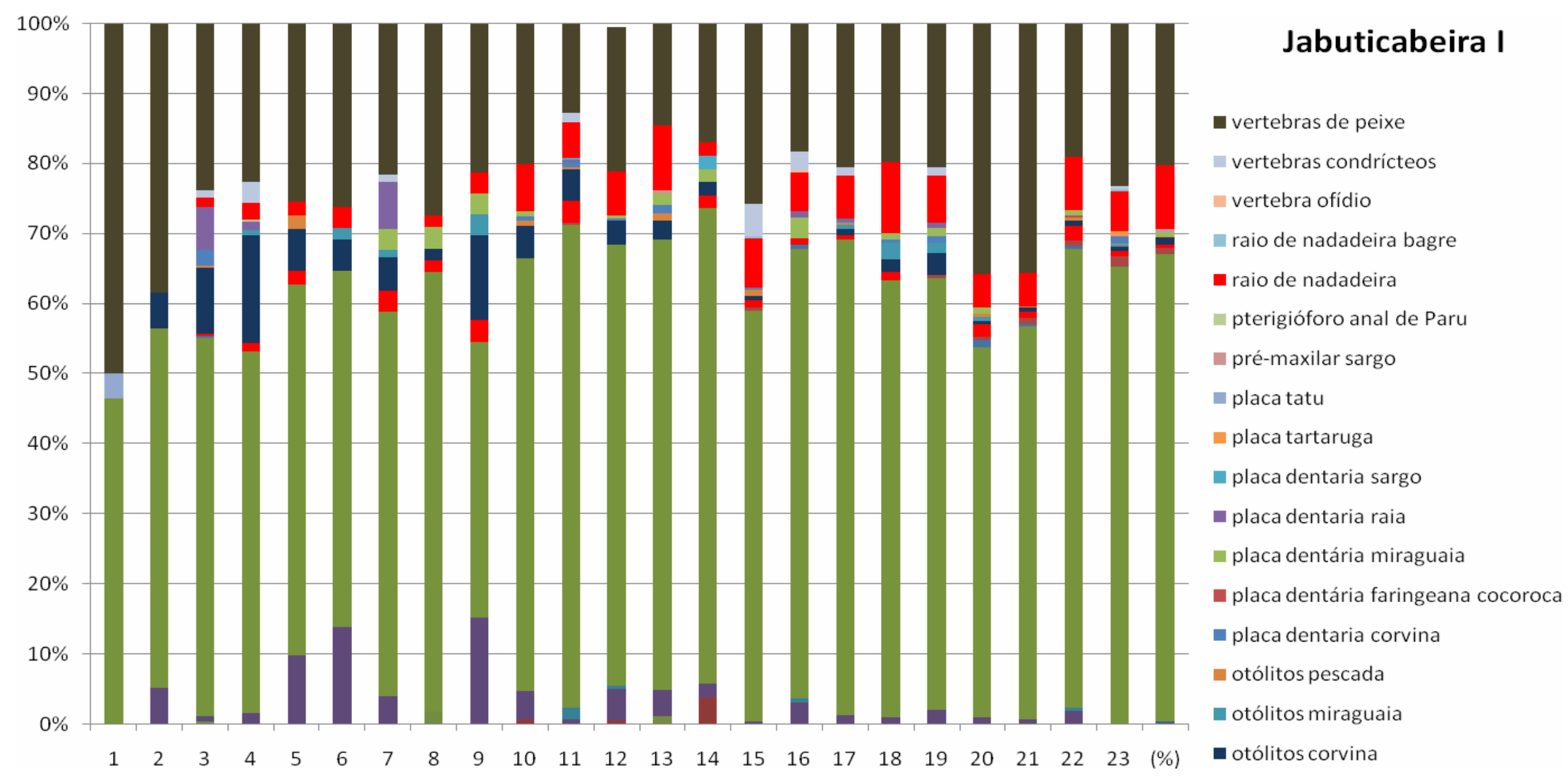

Fig 51. Jab I. Componentes faunísticos da categoria ossos por camadas estratigraficas 
Nossa metodologia de trabalho propõe uma análise do tamanho das conchas para a verificação de mudanças significativas que possam responder as questões em relação à substistiuição do material conchífero nos sítios.

Para tanto, uma subamostra da amostra coletada em campo foi utilizada, e assim pudemos medir o tamanho das valvas da Anomalocardia da base do sítio até seu atual topo.

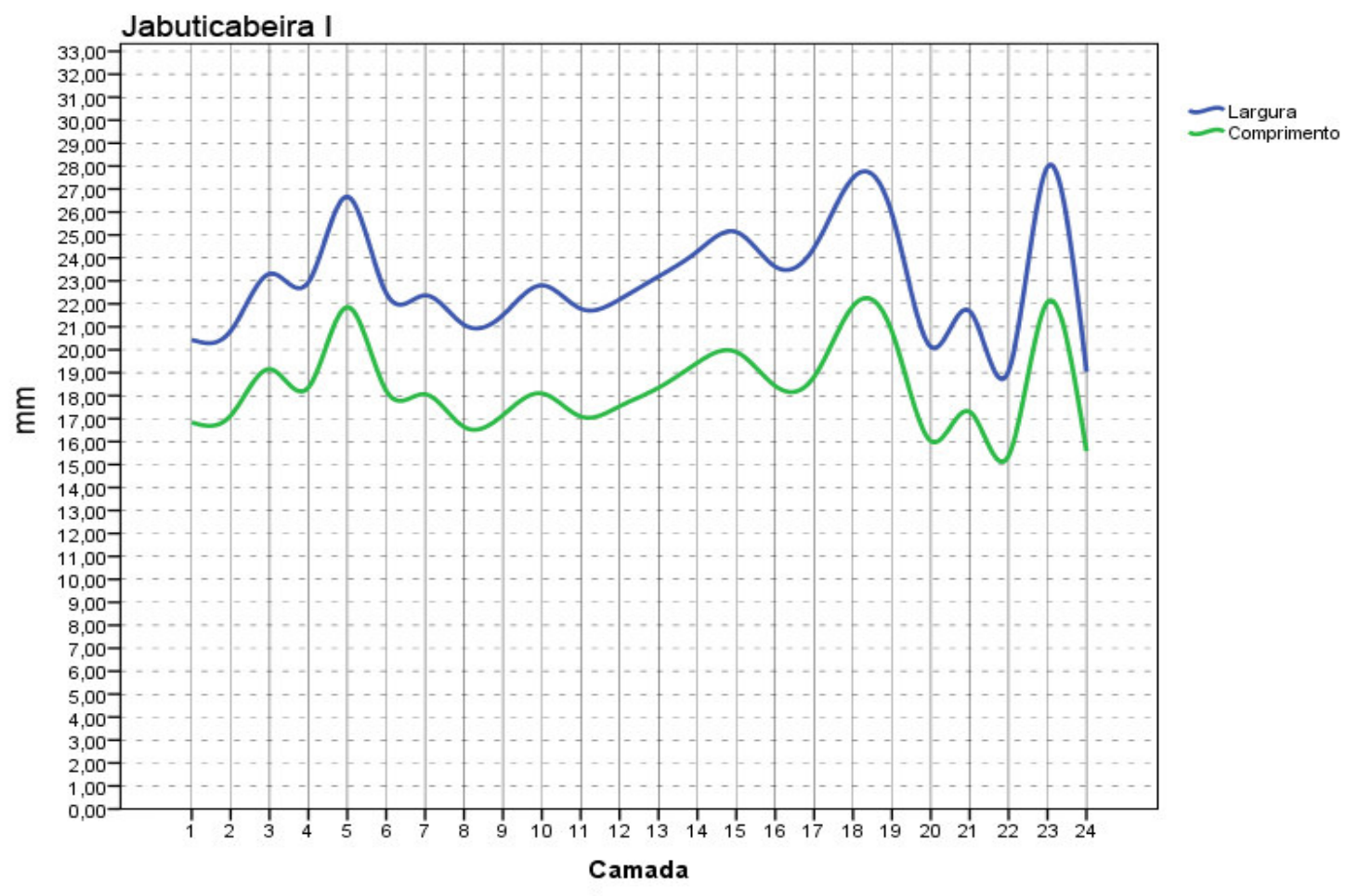

Fig 52. Jab I. Dimensões das valvas de Anomalocardia brasiliana

A partir deste gráfico é possível notar que as valvas mantiveram uma média de tamanho, com exceção das camadas 5, 18 e 23 que apresentaram um aumento significativo nas dimensões das suas valvas, seguido de um declínio acentuado para a camada seguinte ou a próxima, como no caso da camada 18, em que o declínio aparece somente na camada 20. 


\subsection{Levantamento das espécies de conchas presentes nos sítios e seus habitats}

( Hurt 1974; Conquiliologistas do Brasil, 2001)

Ostrea brasiliana $(s p)$ : esta espécie vive em substratos lodosos e arenosos que existem próximos a canais abertos aonde o forte fluxo de marés mantém o sedimento nas colônias. Ocorre também fixada em costões rochosos e raízes de Rhizophora. Esta espécie é uma das principais encontradas em sambaquis da região de Laguna, SC.

Anomalocardia brasiliana: Espécie de bivalve marinho que vive em áreas com fundos arenosos e lodosos, enterradas ou sobre ele. É encontrada a uma pequena profundidade, aproximadamente da superfície ate $30 \mathrm{~cm}$ de profundidade. Ela necessita de água mais salobra do que doce para sobreviver, o que tem acarretado sua diminuição e até mesmo seu extermínio em determinadas áreas da região de Jaguaruna, dado que os canais que conectam as lagoas com o mar aberto estão fechando por conta do assoreamento natural, causando uma queda na salobridade da água. Esta é a espécie mais abundante nos sambaquis da região de Jaguaruna, apesar de seu pequeno tamanho, de aproximadamente $1-2 \mathrm{~cm}$ de comprimento.

Olivancellaria $s p$ : gastrópode marinho que vive em lugares rasos e acima dos sedimentos próximo ao limite da água das marés e em baías.

Neritina virginea: gastrópode marinho que vive em uma grande variedade de ambientes de água salgada, em fundos arenosos e lodosos, enterradas ou sobre ele.

Cyrtopleura sp: bivalve marinho que vive em fundos arenosos e lodosos, enterrados ou sob eles, a uma profundidade de 0 a $10 \mathrm{~cm}$.

Cerithium attratus: vive em áreas com fundos arenosos e lodosos, enterradas ou sob eles, a uma profundidade de 0 a $30 \mathrm{~cm}$. Trata-se de um gastrópode marinho herbívoro de ocorrência razoavelmente comum no litoral brasileiro. 
Crépídula sp: gastrópode marinho comum no litoral brasileiro, vivem sob ou sobre pedras, ou ainda associados a outros seres vivos, parasitando-os. É encontrado a uma profundidade que varia da superfície a $30 \mathrm{~cm}$, e alimenta-se de plantas e algas.

Lucina pectinata: bivalve marinho muito comum em todo o litoral brasileiro, aparece em grande quantidade nos sambaquis da região de Santa Catarina. É encontrado a uma profundidade de 0 a $10 \mathrm{~cm}$ em fundos arenosos e lodosos.

Macoma sp: bivalve marinho comum no litoral brasileiro, vive em fundos arenosos, enterradas ou sob ele, ou ainda em fundos de cascalho de coral, pedra ou conchas. É encontrado a uma profundidade de $0-10 \mathrm{~cm}$.

Nassarius albus: gastrópode marinho comum no litoral brasileiro. Vive em fundos arenosos, enterradas ou sob eles Também em fundos de cascalhos de coral, pedras ou conchas Possuem uma dieta necrófaga, ou seja, alimenta-se de animais mortos e pode ser encontrado a uma profundidade de 0 a $30 \mathrm{~cm}$.

Pugilina morio: gastrópode marinho comum no litoral brasileiro que vive em fundos arenosos e lodosos, enterradas ou sob ele, a uma profundidade de 0 a $10 \mathrm{~cm}$. Alimenta-se de animais mortos.

Olivela sp: Gastrópode marinho que vive em fundos arenosos, enterrado ou sobre eles a uma profundidade de 0 a $10 \mathrm{~cm}$. Trata-se um gastrópode carnívoro, alimentando-se de outros animais.

Mesodesma mactroides: bivalve marinho comum no litoral catarinense, aparece com freqüência nos sambaquis de Santa Catarina. Vive em fundos arenosos e lodosos, enterrado ou sobre eles e é encontrado a uma profundidade de $0-10 \mathrm{~cm}$.

Trachycardium muricatum: bivalve marinho comum no litoral brasileiro. Sua freqüência nos sambaquis da região é alta. Vive em fundos arenosos enterradas ou sobre eles, e também em 
fundos de cascalho de coral, pedras ou conchas. É encontrada a uma profundidade de 0 a 30 $\mathrm{cm}$.

Megalobulimus sp: gastrópode terrestre herbívoro que vive no solo, enterrada ou sob folhas. Aparece em sambaquis litorâneos mais raramente, no entanto em sambaquis fluviais como os presentes no vale do ribeira em São Paulo eles aparecem como a matriz conchífera de construção dos mesmos.

Chione sp: bivalve marinho que vive em fundos arenosos, enterrado ou sobre ele. Pode ser encontrado a uma profundidade de $0-10 \mathrm{~cm}$.

Thais haemastoma:Gastrópode marinho que vive em fundo de cascalho de coral, pedra ou conchas. É encontrado de 0 a $10 \mathrm{~cm}$ de profundidade e alimenta-se de outros animais. Muito comum no litoral brasileiro e presente em grande quantidade nos sambaquis.

Pinctada radiata: bivalve marinho pouco comum no litoral. Aparece muito fragmentada nas amostras dos sambaquis estudados. Vive sob ou sobre pedras.

Donax sp: bivalve marinho que vive em fundos arenosos, enterrado ou sobre ele. Pode ser encontrado a uma profundidade de $0-10 \mathrm{~cm}$.

Vermetídeo: gastrópode marinho já extinto na região de Santa Catarina. Encontrado a 1,5m de profundidade de solos arenosos e cascalhos de corais, pedras e conchas.

Tagelus sp.: Bivalve marinho,vive em fundos lodosos e arenosos,enterradas ou sobre eles. É encontrado a uma profundidade de 0 a $10 \mathrm{~cm}$. 
Levantamento das espécies de peixes presentes nos sítios e seus habitats (Magalhães et al, 1999; Cebula, L; Buckup, P.A. \& Menezes, N.A. (2003))

Corvina - Peixe de escamas da família Sciaenidae, (Micropogonias furnieri). Espécie costeira, vive nos fundos arenosos ou barrentos, de preferência em profundidades de até $100 \mathrm{~m}$. Os jovens e alguns adultos freqüentam os manguezais e estuários, onde se alimentam principalmente de crustáceos, não desprezando os peixes pequenos, caranguejos, siris e mariscos. Também pode entrar na água doce. Ocorre nas Regiões Norte, Nordeste, Sudeste e Sul (do Amapá ao Rio Grande do Sul).

Raia - (Brycon sp) Normalmente vivem solitárias, junto ao fundo arenoso, ou de pequenas pedras. Podem formar pequenos grupos durante a época da migração. Alimentam-se de moluscos, crustáceos e peixes. As arraias marítimas, de 1,50 m a 1,90 m de comprimento, são relativamente comuns e podem alcançar $4 \mathrm{~m}$.

Miraguaia - (Pogonias cromis) Habita as regiões Norte, Nordeste, Sudeste e Sul (do Amapá ao Rio Grande do Sul). Mais comum nas regiões Sudeste e Sul. Peixe de escamas. É uma espécie costeira; vive sobre o fundo da areia, lodo ou cascalho, principalmente em áreas estuarinas próximas a rochas e em canais. Alimenta-se de moluscos, principalmente mariscos, crustáceos e peixes. Migra para águas mais quentes durante o inverno, época da reprodução, quando pode ser encontrada junto a costões rochosos.

Corcoroca - Haemulon Flavolineatum Ocorre em todo o litoral americano do Atlântico. São encontrados em quase todos os tipos de fundo, sendo uma das espécies mais comuns em nosso litoral. São mais frequentes em águas rasas com fundo rochoso e/ou arenoso. Alimentam-se de pequenos peixes, crustáceos e invertebrados.)

Sargo -( Archosargus probatocephalus) Pode medir $90 \mathrm{~cm}$ e alcançar 10 a $12 \mathrm{Kg}$. É um peixe onívoro que se alimenta de invertebrados e vertebrados pequenos. Tem preferência por crustáceos, moluscos, mexilhões e pequenos caranguejos de pedras. Distribui-se por todo o litoral brasileiro, desde o Rio Grande do Sul até o Amapá, podendo ser facilmente encontrado durante o ano todo em águas costeiras e rasas com profundidade de até 50 metros onde as 
pedras se encontram com a areia. Penetra também em águas estuarinas por onde nada em pequenos cardumes. É encontrado em canais litorâneos e fundos pedregosos, coral ou outros que tenham frestas e tocas onde se costumam abrigar, sendo normalmente mais ativos durante a noite.

\section{Bagre - (Cathorops spixii, Arius spixii e Tachysurus spixii)}

Trata-se de um peixe bastante comum em toda a costa do Brasil A espécie, que tem três pares de barbilhos abaixo dos maxilares em forma de fita, possui um hábito alimentar onívorodetritívoro, isto é, alimenta-se de uma considerável variedade de itens, incluindo animais e vegetais, além de consumir uma quantidade considerável de matéria orgânica. O bagre é muito comum no Oceano Atlântico, abundante em quase toda a costa brasileira. Costuma freqüentar as praias, estuários, manguezais e foz de rios. Durante a época da desova, entra na água doce. Dificilmente os peixes desta espécie são encontrados em águas muito profundas. Normalmente os exemplares andam em grupo e têm hábitos noturnos; mas em águas turvas, ocasionadas pelas correntes marítimas, é possível encontrá-los durante o dia.

Baiacu - (Diodon Hystrix) Ocorrem em todos os mares, em águas tropicais. Vivem em fundos coralinos e rochosos em águas costeiras. Podem inflar e levantar seus espinhos, causando ferimentos dolorosos. Alimentam-se de moluscos, crustáceos e algas marinhas.

Pescada - (Cynoscion virescens) Peixe ósseo da família Sciaenidade que vive em cardumes e tem hábitos diurnos.Apresenta em média $45 \mathrm{~cm}$ de comprimento e pesa $1,5 \mathrm{~kg}$. Ela é encontrada em pequenos ou grandes cardumes nadando próxima ao fundo durante o dia e movendo-se à noite para a superfície. Alimenta-se, principalmente, de camarões e, ocasionalmente, de pequenos peixes. A espécie habita praticamente todo o litoral brasileiro,

Paru - (Pomacanthus paru ) Facilmente encontrados em toda a costa ocidental do Atlântico, São encontrados normalmente em casais. Alimentam-se de pequenos animais e algas.

Carangueijo - crustáceo, da ordem decaphoda, e da família portunidae que vive nas algas marrons dos lagamares, desde a linha da maré alta até uma profundidade de 6 metros. Adaptase a qualquer espécie de água, mesmo na água salobra dos estuários. Come de tudo, desde peixes mortos até carangueijos menores. 
Siri - crustáceo que vive em regiões costeiras, geralmente associado a estuários. É do grupo dos crustáceos decápodes nadadores que apresentam o último par de pernas em forma de remo, o que os difere dos caranguejos. 


\section{Cap VI - Conclusões}

Graças aos estudos mais recentes realizados em sambaquis, temos hoje em dia uma visão a respeito deles que perpassa por questões rituais, e deixa de lado a simples formulação de que estes eram formados por acúmulos de lixo.

Considerando esse fato, interpretamos os sambaquis como sítios monumentais, construídos com a finalidade de preservação dos corpos dos mortos da população sambaquieira, e que, para sua elevação e construção foram utilizados materiais resistentes ao tempo e que chamam a atenção devido ao seu formato e cor esbranquiçada em meio a paisagem. Partimos então do pressuposto da intencionalidade da deposição do material para a construção de sítios funerários.

A partir das inúmeras datações realizadas pela equipe do projeto temático, foi possível estabelecer uma cronologia da ocupação dos povos sambaquieiros da região de pesquisa, e assim verificar que essa ocupação perdurou na região por milhares de anos, aproximadamente 6000, sendo possível inclusive estabelecer três diferentes períodos de ocupação.

Os três sambaquis estudados nesta dissertação fazem parte dos dois primeiros períodos, os assim denominados Pré-Clássico e Clássico. O período Pré-Classico apresenta sítios de menores dimensões, localizados mais longe da linha de costa atual, com datas que vão de 7500 anos AP a 4500 anos AP; e fazem parte deste grupo os sítios Caipora e Lageado. O sambaqui Jab. I entra no período Pré-Clássico considerando a calibragem das datas, que é de 4840 e 4870 anos AP, para em seguida fazer parte já do período Clássico, onde permanece até o final de sua construção. Na realidade a data de topo deste sambaqui não representa o fim de sua construção, dado que ele foi intensamente minerado. É muito provável que ele tenha estado em atividade durante os três períodos, já que os relatos dos moradores dizem que uma camada de terra preta, assim como a do Jab. II recobria a superfície do sambaqui. O período Clássico se caracteriza por sambaquis funerários de dimensões bem maiores, que foram construídos na região e acompanharam o recuo da lagoa conforme a retração do nível do mar. As datas para os sítios deste período vão de 4500 anos AP até 1500 anos AP aproximadamente, e caracterizam um período de explosão demográfica da sociedade sambaquieira. 
A partir dos resultados delineados no capítulo anterior, pudemos concluir que os sambaquis Caipora e Lageado apresentaram como matriz construtiva dos sítios conchas de Ostrea sp e sedimento argiloso e areno-argiloso para a elevação dos sítios. Seguindo a mesma metodologia, a conclusão para o sambaqui Jaboticabeira I foi de que este tinha como matriz conchífera conchas de Anomalocardia brasiliana, misturadas a um sedimento arenoso.

A hipótese inicial de superexploração do material malacológico, que acarretaria em uma diminuição da oferta e do tamanho das valvas das espécies mais coletadas não se consolidou, dado que em nenhum dos três sítios pudemos notar uma diminuição contínua do tamanho destas.

Os critérios para inferir super-exploração de bancos de moluscos, baseados em Classen (1986 e 1998) são:

- Decréscimo das espécies preferenciais de coleta conforme o depósito se desenvolve.

- Diminuição do tamanho das conchas das amostras de base em relação às de topo do depósito.

- Espécies de captura mais difícil crescem em número conforme o depósito aumenta.

- Espécies de processamento mais difícil crescem em número.

- Redução continuada da idade das conchas desde a base até o topo do depósito.

Nenhuma das bases de definição de superexploração propostas por Classen foram evidenciadas. As espécies preferenciais continuaram da base até o topo dos sambaquis verificados. O tamanho das conchas não diminuiu, todas as espécies presentes no registro mantiveram suas proporções, com exceção de algumas poucas camadas no sambaqui Jaboticabeira I que apresentaram mariscos em detrimento de Anomalocardia, para logo em seguida voltarem a conter as espécies majoritárias, além de que não apareceram espécies de processamento difícil, elas se mantiveram praticamente as mesmas do começo ao fim. Somente a verificação da idade das conchas não foi possível avaliar, dado que não disponibilizamos da tecnologia adequada para a verificação deste evento.

O que vimos a partir dos gráficos de tamanho das espécies foi um aumento seguido de diminuição das dimensões, que poderia ser explicado se considerarmos que para os eventos funerários de elevação dos sambaquis teriam ocorrido grandes episódios de coleta. Piazza 
(1966), Prous (1992) e Afonso e DeBlasis (1994), já atentavam para o fato de que camadas construtivas mais homogêneas, formadas por praticamente uma única espécie de concha, pode ser relativa a episódios de rápida acumulação, o que corrobora o fato de que poucas e eventuais coletas deste material possam ter sido realizadas para a elevação da plataforma funerária do sítio, sem que estas afetassem o banco de moluscos de forma a impedir uma reprodução ou acelerá-la, fazendo com que os moluscos atingissem uma maturidade sexual muito cedo, diminuindo seu tamanho.

A segunda hipótese, de que a mudança de material construtivo teria ocorrido devido à reação dos construtores a algum efeito do ambiente é mais plausível. No caso dos sambaquis Caipora e Lageado, compostos majoritariamente por Ostrea sp, encontramos o ambiente ideal para o desenvolvimento deste molusco, no qual uma base granitóide entra em contato com a água salgada. O sítio Jaboticabeira I, que também está ancorado em base rochosa, mas que apresenta em sua composição conchas de Anomalocardia como matriz, apresenta também camadas inteiras compostas de ostras, o que significaria que o recurso estaria disponível, mas apenas para algumas poucas coletas em determinados momentos, além de que o entorno arenoso do sítio é propício para o desenvolvimento do bivalve Anomalocardia.

Ou seja, com o recuo do mar, o ambiente mais propício para o desenvolvimento da Ostrea sp ficou reduzido, enquanto que com o aumento da temperatura da água em consequiência da formação de lagoas menores e mais rasas, a Anomalocardia teria encontrado um habitat ideal para sua proliferação.

Em relação a mudança de material construtivo da Anomalocardia para a Terra Preta, a explicação pode vir a ser cultural, talvez contato com outras populações que atingiram a região por volta de 2000 anos AP, já que não foi observada diminuição contínua das dimensões das valvas nem no sambaqui Jaboticabeira I e nem no Jab II (Barbosa, 2008). Além disso, imensos lençóis naturais de Anomalocardia estão presentes na região, desde o período de construção dos sambaquis. Ou seja, a mudança não teria ocorrido devido a ausência destes bivalves, já que podemos considerá-los (os lençóis) como marcadores biológicos de excesso de oferta, a não ser que houvessem determinados tabus que os impedissem de construir os sítios com conchas já mortas..

Outra conclusão alcançada por esta pesquisa foi que, analisando os gráficos de tamanho e largura das valvas de Anomalocardia, é possível notar um padrão bem regular das dimensões no que se refere ao comprimento e largura destas. Desta maneira, duas medidas 
tornaram-se desnecessárias, sendo possível estabelecer um padrão com apenas uma das medidas, já que estas apresentam um crescimento simétrico em relação ao comprimento e largura.

Com relação aos ossos encontrados nos três sítios estudados nesta dissertação, concluímos que a esmagadora maioria dos vestígios eram provenientes dos recursos aquáticos da região, tanto do mar quanto das lagoas, com apenas dois fragmentos de animais cuja origem não remete a água. Isso pode significar que nem mesmo os sambaquieiros mais antigos da região exploraram ambientes de floresta para alimentar-se ou para alimentar seus mortos em oferendas. Baseado nesta afirmação, podemos inferir que estes grupos que ocuparam o litoral sul de Santa Catarina já atingiram a região adaptados ao modo de vida pescador tão comum aos sambaquieiros de todo o litoral, não se caracterizando como uma população autóctone, apesar das datas recuadas. O caminho utilizado por estes povos para alcançar a área de estudo ainda não é possível delinear, mas acreditamos que com mais pesquisas e com um maior número de datações ao longo dos anos subseqüentes ficará mais clara a origem destes povos e suas rotas de dispersão.

Por fim, nenhum trabalho arqueológico pode-se considerar finalizado e exato, dado que trabalhamos sempre com amostras, com um universo pequeno se comparado ao universo total de sítios. Por esse motivo, acreditamos que existe a necessidade de um maior número de trabalhos relativos ao paleoambiente da região, para que dessa maneira seja possível cruzar os dados paleoambientais com os dados retirados de análises dos sítios, e assim ampliar o leque de conhecimento da região através do qual poderemos no futuro inferir modelos com mais propriedade. 


\title{
REFERÊNCIAS BIBLIOGRÁFICAS
}

\author{
AFONSO, MARISA C. \& PAULO DEBLASIS
}

1994 Aspectos da formação de um grande sambaqui: alguns indicadores em Espinheiros II, Joinville, SC. Revista do museu de Arqueologia e Etnologia 4, Museu de Arqueologia e Etnologia da Universidade de São Paulo.

\section{ANDRADE LIMA, T.}

1991, Dos mariscos aos peixes: um estudo zooarqueológico de mudança de subsistência na pré história do Rio de Janeiro. São Paulo, 691p. Tese de Doutoramento. Faculdade de Filosofia Letras e Ciências Humanas - Universidade de São Paulo.

1999-2000.Em busca dos frutos do mar: os pescadores-coletores do litoral centro-sul do Brasil. IN: Revista USP. São Paulo, Universidade de São Paulo, no. 44, 270-327,

ANGULO, RJ; GIANNINI, P.C.; SUGUIO, K; PESSENDA, L. C.

1999 Relative sea level changes in the last 5500 in southern Brasil (Laguna-Imbituba region, Santa Catarina state) based on vermetid ${ }^{14} \mathrm{C}$ ages. Marine Geology, v. 159, 323-339.

ANGULO,R.J; GIANINI, P.C.; SUGUIO, K; L.C.R.

1996.Variação do Nível Relativo do mar nos últimos 5550 na região de LagunaImbituba (Santa Catarina), com base em datações radiocarbônicas de tubos de vermetídeos. Anais do XXXIX Congresso Brasileiro de Geologia, vol. 5, Simpósios, Salvador, Bahia, p. $281-284$,

\section{BARBOSA, MARCIA; GASPAR, MARIA DULCE; BARBOSA, DEBORA R.}

1994. A organização espacial das estruturas habitacionais e distribuição dos artefatos no sítio Ilha da Boa Vista I, Cabo Frio, RJ. Revista do Museu de Arqueologia e Etnologia da 
Universidade de São Paulo. Museu de Arqueologia e Etnologia da Universidade de São Paulo, 4: 31-38.

BARBOSA, P. N;

2007 A Coisa Ficou Preta: Estudo do processo de formação da terra preta do sítio arqueológico Jabuticabeira II. Tese de Doutorado. MAE-USP.

BANDEIRA, D. R.

1992, Mudança na estratégia de subsistência. O sítio arqueológico Enseada I - Um estudo de caso. Florianópolis, 130 p. Dissertação de Mestrado, Universidade Federal de Santa Catarina.

BECK, A.

1972, A variação do conteúdo cultural dos sambaquis do litoral de Santa Catarina. São Paulo, 286 p. Tese de Doutorado, Faculdade de Filosofia, Letras e Ciências Humanas Universidade de São Paulo.

BELÉM , F.

2007. Análise da indústria lítica do Sambaqui Jabuticabeira II e sua contextualização intra-sítio. Relatório FAPESP.

BENDAZOLLI, C.

2007, O processo de formação dos Sambaquis: Uma leitura estratigráfica dósítio Jabuticabeira II, SC. Dissertação de Mestrado, Museu de Arqueologia e Etnologia Universidade de São Paulo,

BIANCHINI, G. F.

2008. Fogo e Paisagem: evidências de práticas rituais e construção do ambiente a partir da análise antracológica de um sambaqui no litoral sul de Santa Catarina. Dissertação de mestrado, Museu Nacional, UFRJ. 
BUCKUP, P.A. \& MENEZES, N.A. (EDS.)

2003. Catálogo dos Peixes Marinhos e de Água Doce do Brasil. 2.ed. disponível em $<</ /$ www.mnrj.ufrj.br/catalogo/ >> acessado em 18 de outubro de 2009

\section{CALIPPO, F. R.}

2004 Os sambaquis submersos de Cananéia: um estudo de caso de arqueologia subaquática. Dissertação de mestrado. Museu de Arqueologia e Etnologia da Universidade de São Paulo.

\section{CARUSO JR ,}

1995. Mapa Geológico e de recursos minerais do sudeste de Santa Catarina. Programa Cartas de Síntese e Estudos de Integração Geológica 1, Departamento Nacional de Produção Mineral, Brasília,

\section{CEBULA, Luciano}

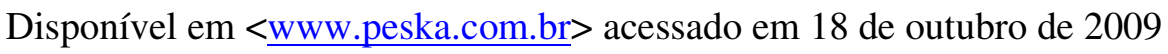

\section{CLASSEN, C.}

1986. Shellfishing seasons in the prehistoric Southeastern United States, American Antiquity 51: 21-27

1991. Normative Thinking and Shell Bearing Sites. In: Archaeological Method and Theory. Tucson. University of Arizona Press, vol. 3 249-298. Press.

1998. Shells. Cambridge Manuals in Archaeology. Cambridge. Cambridge University

\section{CONQUILIOLOGISTAS DO BRASIL}

Autores: Vanin , Sérgio ; Cunha, Carlos Magenta; Esteves, Celso. Disponível em: $<$ www.conchasdobrasil.com.br $>$ acessado em 18 de outubro de 2009.

DEBLASIS, P. A. D; FISH, P.; FISH S.;EGGERS, S; LAHR, M. M.; FIGUTI, L; AFONSO, M. C.; GASPAR, M. D.

1998 a. Padrões de assentamento e formação de sambaquis em Santa Catarina In:. Revista do Museu de Arqueologia e Etnologia da Universidade de São Paulo, v. 8: 319-321.

DEBLASIS, P. A. D; FISH, P.; FISH S.; GASPAR, M. D. 
1998, Some references for the discussion of complexity among the sambaqui mound builders from the southtern shores of Brazil. In: Revista de Arqueología Americana, v. 15,

DEBLASIS, P.; KNEIP, A.; SHEEL-YBERT, R.; GIANNINI, P.C.; GASPAR, M.D.

2007. Sambaquis e Paisagem: Dinâmica natural e arqueologia regional no litoral sul do Brasil. In: Revista de Arqueologia Sul-Americana 3(1): 29-61,

DE MASI, M. A. N.

1990. Escavações Arqueológicas do Pe. João Alfredo Rohr: O Assentamento da Armação do Sul, SC, Brasil. Dissertação de mestrado. Centro de Educação e Humanismo UNISINOS

1999. Prehistoric Hunter-gatherer Mobility um the Southern Brazilian Coast: Santa Catarina Island. Tese de Doutoramento, Stanford University,

FARIAS D. S. F \& DEBLASIS, P. A. D

2006. Anais do V Encontro do Núcleo Regional Sul da Sociedade de Arqueologia Brasileira - SAB/Sul. Rio Grande. RS

FIGUTI, L.

1992. Les sambaquis COSIPA (4200 à 1200 ans BP): étude de la subsistance chez lê peuples de Pêcheux-ramasseurs de bivalves de la cote centrale de l'état de São Paulo, Brésil. Thése de Doctorat, Museum National d'Historie Naturelle, Institut de Paleontologie Humaine, Paris, $212 \mathrm{p}$.

1993 a.Os sambaquis COSIPA (4200 a 1200 anos AP): estudo da subsistência dos povos pescadores coletores pré históricos. In: Reunião Científica da Sociedade Brasileira de Arqueologia, 7. João Pessoa. Resumos, p. 81,

1993 b. Dados preliminares sobre a subsistência pré-histórica do Mar Virado. IN: Reunião Científica da Sociedade Brasileira de Arqueologia, 7. João Pessoa. Resumos, p 171. 
1993c .O Homem pré histórico, o molusco e o sambaqui: considerações sobre a subsistência dos povos sambaquianos.In; Revista do Museu de Arqueologia e Etnologia da Universidade de São Paulo, 3: 67-80,

FIGUTI, L.; KLÖKLER, D. M.

1996. Resultados preliminares dos vestígios zooarqueológicos do sambaqui Espinheiros II, Joinville, SC. In: Revista do Museu de Arqueologia e Etnologia da Universidade de São Paulo. São Paulo, Vol. 6: 160-187

\section{FRÓES ABREU, S.}

1932. A importância dos sambaquis no estudo da pré história do Brasil. Revista da Sociedade de Geografia. Rio de Janeiro, RJ, 35: 2- 15,

GASPAR, M. D.

1994-95. Espaço, ritos funerários e Identidade pré-histórica. Revista de Arqueologia. V. 8, n 2. p. 221-237, São Paulo,

1991 a. Aspectos da organização de um grupo de Pescadores, Coletores e Caçadores: Região compreendida entre a Ilha Grande e o delta do Paraíba do Sul, Estado do Rio de Janeiro. Tese de Doutoramento, Faculdade de Filosofia, Letras e Ciências Humanas/ Universidade de São Paulo. São Paulo, 362 p,

1991 b.Construção de sambaqui. In: Reunião científica da Sociedade de Arqueologia Brasileira, 6. Rio de Janeiro. Resumos,

1996. Território de exploração e tipo de ocupação dos pescadores, coletores e caçadores que ocuparam o litoral do Estado do Rio de Janeiro. CLIO-Série Arqueologia. V. 11, p. 153-174,

2000. Sambaqui: arqueologia do litoral brasileiro. Jorge Zahar, Rio de Janeiro,

GASPAR, M. D.; DE BLASIS, P. A. D. 
1992. Construção de Sambaquis. Anais da VI Reunião da Sociedade de Arqueologia Brasileira. P. 811-820

\section{GAPLAN/SC.}

1986 Atlas de Santa Catarina. Rio de Janeiro, Aerofoto Cruzeiro,

GIANNINI, P. C. F.

1993 Sistemas deposicionais no quaternário costeiro entre Jaguaruna e Imbituba, SC. Tese de doutoramento. IGC-USP. São Paulo,

GIANNINI, P. C. F.; SAWACUCHI, A. O.; MARTINHO, C.

2001. A estratigrafia de seqüências na evolução das dunas costeiras de Santa Catarina, sul do Brasil. In: V REQUI/ I CQPLI, Lisboa,

HERING, A.

2005. Estudo dos artefatos osteodontomalacológicos do sambaqui Jaboticabeira II, Jaguaruna, Santa Catarina. Relatório FAPESP,

HESSE, A ; PRIEUR, A.

1999. Compter ou peser..? Valeurs absolues ou relatives..? (à propôs d'amas coquilliers antro piques sur la cote ouest de la península d'Oman.)

HURT, W.R.

1974. The interrelatioship between the natural environment and four Sambaquis, coast of. Santa Catarina, Brazil. Occasional Papers and Monographs, Bloomington, 1, Indiana University Museum. 
1983. Adaptações marítimas no Brasil. Arquivo do Museu de História Natural. V.8 61-72, Belo Horizonte, UFMG

\section{IHERING, $\mathrm{H}$.}

1907. A Antropologia do Estado de São Paulo. Revista do Museu Paulista. São Paulo, 7: 202-257

\section{KEOGH , M.J. QUINN, G.P., KING, A.}

1993 Correlation between human collecting and intertidal molluscs population on rocky shores. Consevations, v. 7: 378-390.

\section{KLÖKLER, D. M.}

2001. Construindo ou deixando um sambaqui? Análise de sedimentos de um sambaqui do litoral meridional brasileiro - processos formativos. Região de Laguna, SC. Dissertação de Mestrado. Faculdade de Filosofia, Letras e Ciências Humanas da Universidade de São Paulo. São Paulo,

2008 Food for Body and Soul: Mortuary Ritual in Shell Mounds. Laguna-Brazil. University of Arizona

\section{KNEIP, A.}

2004. O povo da Lagoa: uso do SIG para modela mento e simulação na arqueológica do Camacho. Tese de Doutoramento. Museu de Arqueologia e Etnologia da Universidade de São Paulo. São Paulo

\section{KRONE, R.}

1902 Contribuições para a etnologia paulista. Revista do Instituto Histórico e Geográfico de São Paulo. V. 7 , 471-182.

1908. Exploração ao Rio Ribeira de Iguape. Informações ethinográphicas do Vale do Rio Ribeira de Iguape. São Paulo: Tipographia Brasil de Rothschild e cia. Comissão Geográphica do Estado de São Paulo. pp 23 - 31 
LEÃO, E. S.

1919. Antonina Pré-histórica. Arquivos do Museu Nacional, Rio de Janeiro, 22: 231240

LEE, R. B. e DEVORE (eds)

1968 Man the Hunter. Aldine, Chicago,.

LEONARDOS, O.

1938. Concheiros naturais e Sambaquis. Publicação do serviço de fomento da Produção Mineral. Avulsos no. 37. Rio de Janeiro. Departamento Nacional da Produção Mineral. 1-109p.

MAGALHÃES, LUCIO ; CORENZAN JUNIOR, HUGO

1999. Scubadivers. Disponível em <<www.scubadiver.com.br $>>$ acessado em 10 de dezembro de 2009.

MANNINO, MARCELLO A; THOMAS, KENNETH D.

2002. Depletion of a resourse? The impact os prehistoric human foraging on intertidal mollusc communities and its significance for human settlement, mobility and dispersal. Word Archaeology. vol. 33 (452-474)

NIMER, E.

1989 Climatologia do Brasil. 2. Ed. Rio de Janeiro: IBGE

ORSELLI , L.

1986. Climatologia. GAPLAN/SC. In: Atlas de Santa Catarina. Aerofoto cruzeiro, pp 38-39.Rio de Janeiro

PEIXOTO, S. A. 
2008. Pequenos aos montes: Uma análise dos processos de formação dos sambaquis de pequeno porte do litoral sul de Santa Catarina. Dissertação de mestrado, Museu Nacional da Universidade Federal do Rio de Janeiro.

PERLMAN, S. M.

1980. An optimum diet model, coastal variability, and Hunter-gatherer behavior. In: Advances in Archaeological Method and Theory. 3: 257-301

\section{PLENS, C.}

2007 Sítio Moraes: uma biografia não autorizada. Análise do processo de formação de um sambaqui fluvial. Tese de doutoramento, Museu de Arqueologia e Etnologia da Universidade de São Paulo. São Paulo .

PIAZZA, W. F.

1966a Estudos de Sambaquis. Série Arqueologia, v. 2 Instituto de Antropologia, UFSC, Florianópolis

1966 b O Sambaqui Ponta das Almas. Série Arqueologia, v. 21966 Instituto de Antropologia, UFSC, Florianópolis

PROUS , A.

1992. Arqueologia Brasileira. Brasília: Editora Universidade de Brasília,

PROUS, A \& PIAZZA, W.

1977. Documents pour la préhistorie du Brésil meridional 2: létat de Santa Catarina. Cahiers d'Archéologie d'Amérique du Sul. 4. Paris, EHESS

REITZ \& WING,

1999. Zooarchaeology. Cambridge University Press, 
RENOUF, M. A. P.

1984. Northern coastal hunter-fishers: an archaeological model. World

Archaeology 16(1):18-27,

ROHR, J. A.

1969. Os sítios arqueológios do município sul-catarinense de Jaguaruna. Pesquisas, São Leopoldo, 22, 1-37.

SCHIMITZ, P.I.

1980. A evolução da cultura no sudoeste de Goiás. Pesquisas, Antropologia n. 31 pp.185-225.

1987 Prehistoric hunter and gatherers of. Brazil. Journal of. World Prehistory, v. 1

SCHEEL-YBERT, R.

2001 Man and vegetation in southeastern Brazil during the late Holocene. Journal of. Archaeological Science, v. 28,

SCHEEL-YBERT, R.; KLOKLER, D.M; GASPAR, MADU, FIGUTI, L.

2005-2006 Proposta de Amostragem padronizada para macro-vestígios bioarqueológicos: antracologia, arqueobotânica, zooarqueologia. Revista do Museu de Arqueologia e Etnologia, 15-16: 139-163. USP- São Paulo,

STORTO, C.; EGGERS, S. LAHR, M.M.,

1999. Estudo preliminar das paleopatologias da população do sambaqui Jaboticabeira II, Jaguaruna, SC. Revista do Museu de Arqueologia e Etnologia da Universidade de São Paulo, v. 9,

STRAHLER, A. N.

1977. Geografia Física, Barcelona: Omega, 
STEWARD, JULIAN H.

1955 Theory of cultural change. University of Illinois Press, Urbana,

SUGUIO, K; MARTIN, L;BITTENCOUT, A; DOMINGUEZ, J; FLEXOR, J-M; AZEVEDO, A.

1985. Flutuações do nível relativo do mar durante o quaternário superior ao longo do litoral brasileiro e suas implicações na sedimentação costeira. Revista brasileira de geociências, v. 15

VILLAGRÁN, X.

2008 Análise de Arqueofácies na camada preta do sambaqui Jabuticabeira II. Dissertação de Mestrado. Museu de Arqueologia e Etnologia da Universidade de São Paulo.São Paulo,

\section{WALKER, ROGER}

1976. Fácies and Fácies models. General introduction. In Fácies Models. Editado por Roger Walker, Geosciences, Toronto.

WASELKOV, G.A

1987 Shellfish gathering and Shell midden archaeology IN: SHIFFER, M.B. (ED) Advances in archaeological method and theory. Orlando: Academic Press,

\section{WESOLOWSKI, V.}

2000. A prática da Horticultura entre os Construtores de Sambaquis e Acampamentos litorâneos da Região da Baía de São Francisco, Santa Catarina: uma abordagem BioAntropológica. Dissertação de Mestrado. Faculdade de Filosofia, Letras e Ciências Humanas da Universidade de São Paulo 
WIERNER, K.

1876. Estudos sobre os sambaquis do sul do Brasil. In: Archivos do Museu Nacional do Rio de Janeiro. Imprensa Industrial, Rio de Janeiro, 1: 3-20,. 
ANEXOS 


\section{Sedimentos}

\section{Sed. Arenoso}

Sed. Argiloso

\section{Sed. Orgânico - Pouco}

\section{Sed. Orgânico - Médio}

\section{Sed. Orgânico - Denso}

\section{Marcações}

Amostra zoológica

Amostra para datação 


\section{Concha inteira - rarefeita}

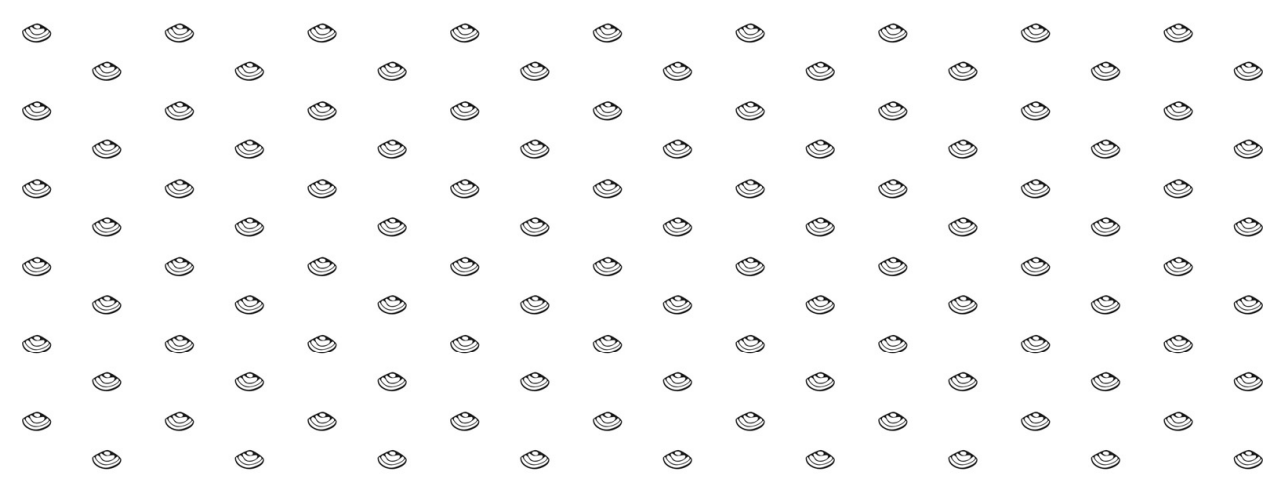

\section{Concha inteira - média}

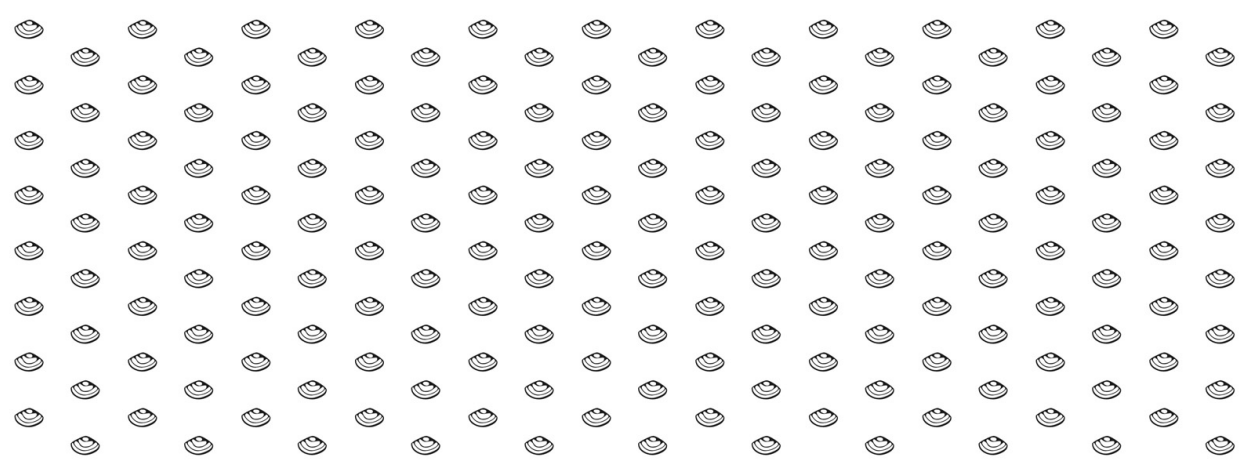

\section{Concha inteira - densa}

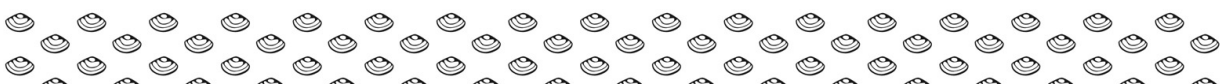

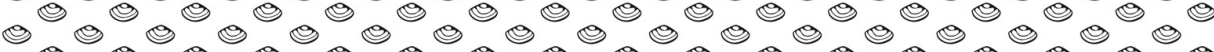

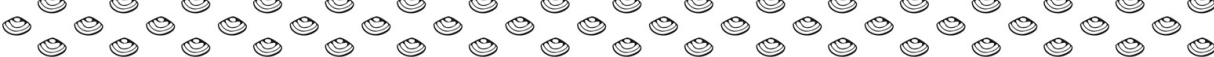

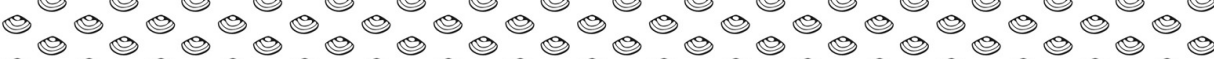

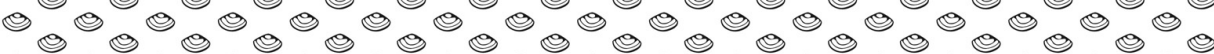

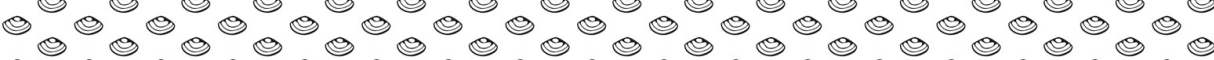

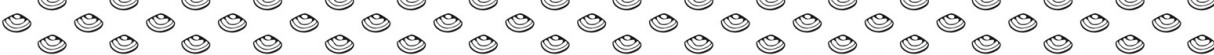

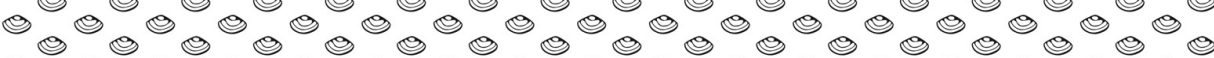

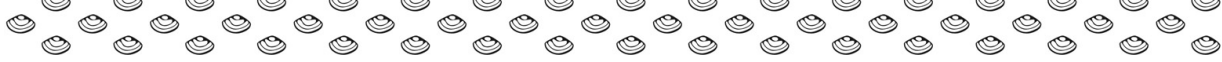




\section{Concha inteira/fragmentada - rarefeita}

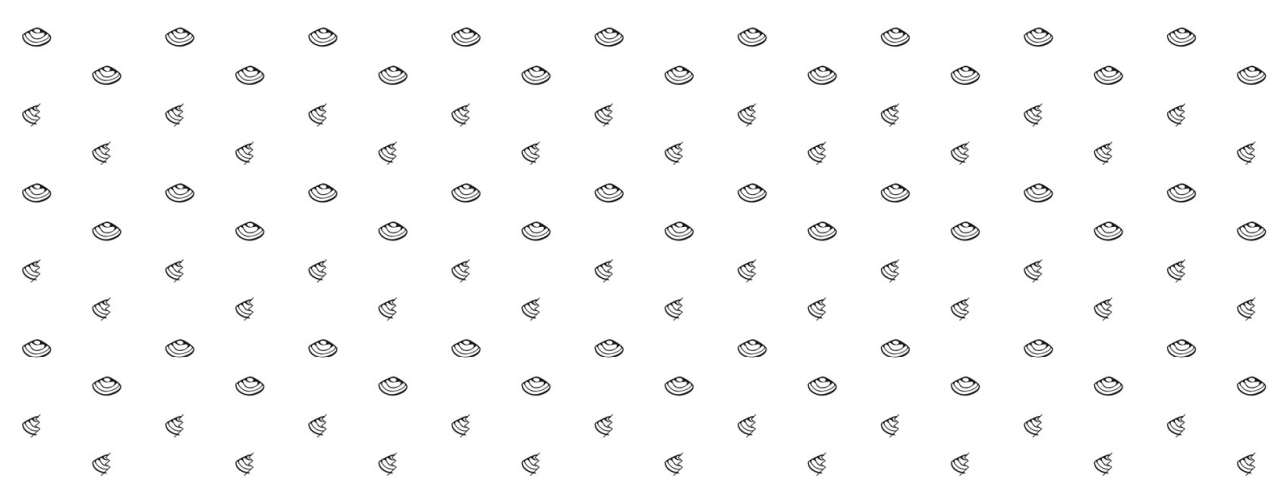

\section{Concha inteira/fragmentada - média}

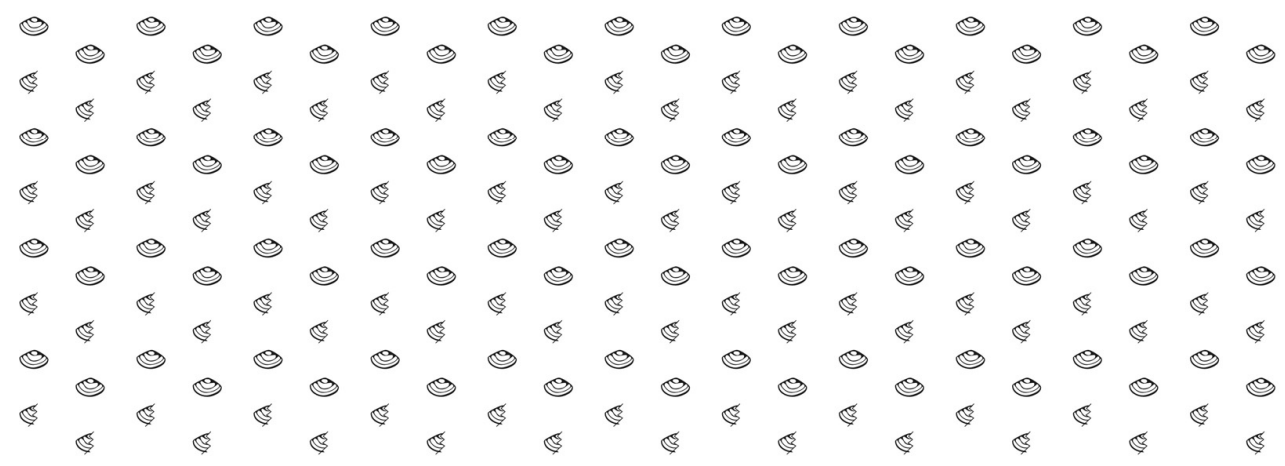

\section{Concha inteira/fragmentada - densa}

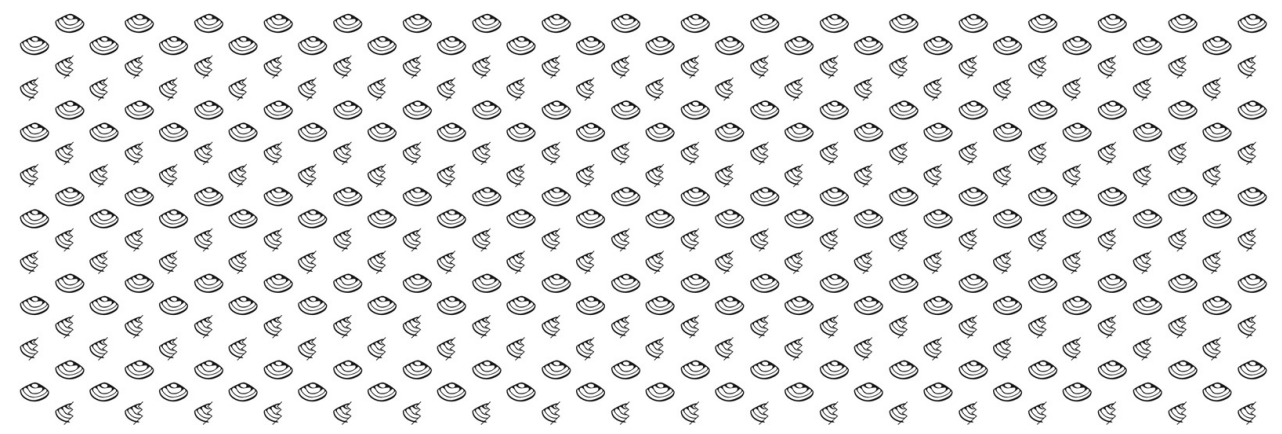




\section{Concha inteira/moída - rarefeita}

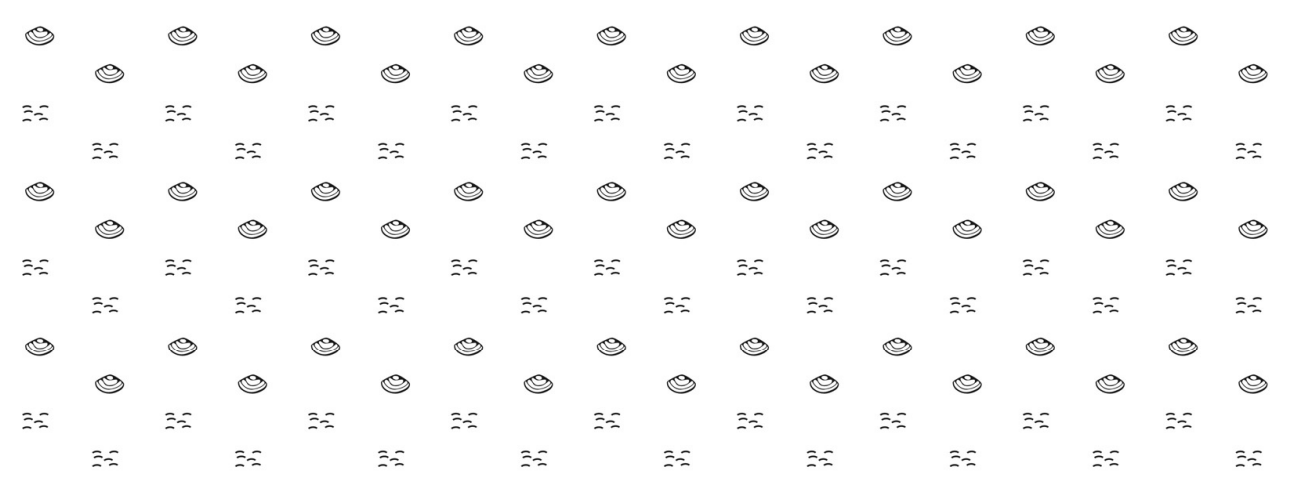

\section{Concha inteira/moída - média}

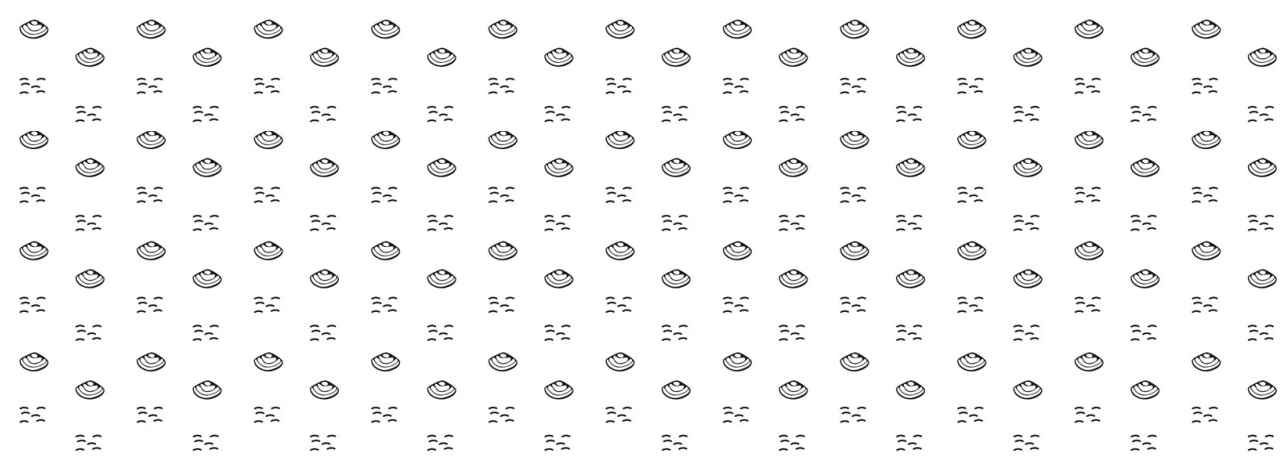

\section{Concha inteira/moída - densa}

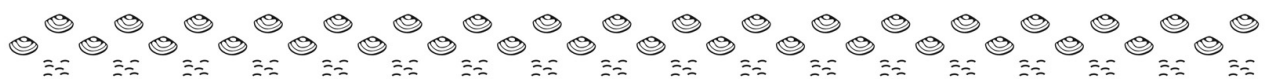

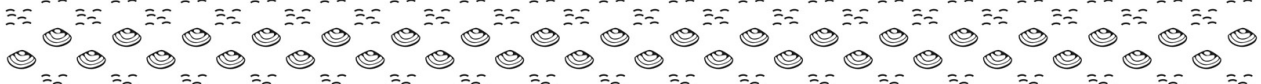
$\sum=$

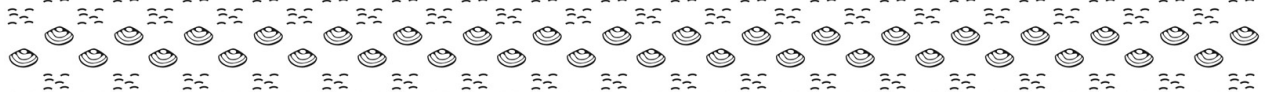

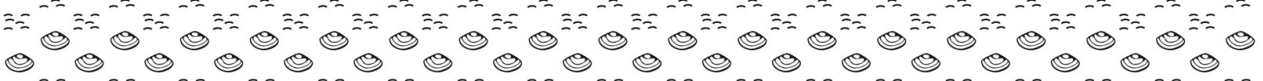

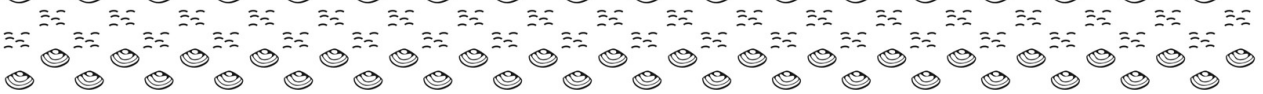




\section{Concha fragmentada/moída- rarefeita}

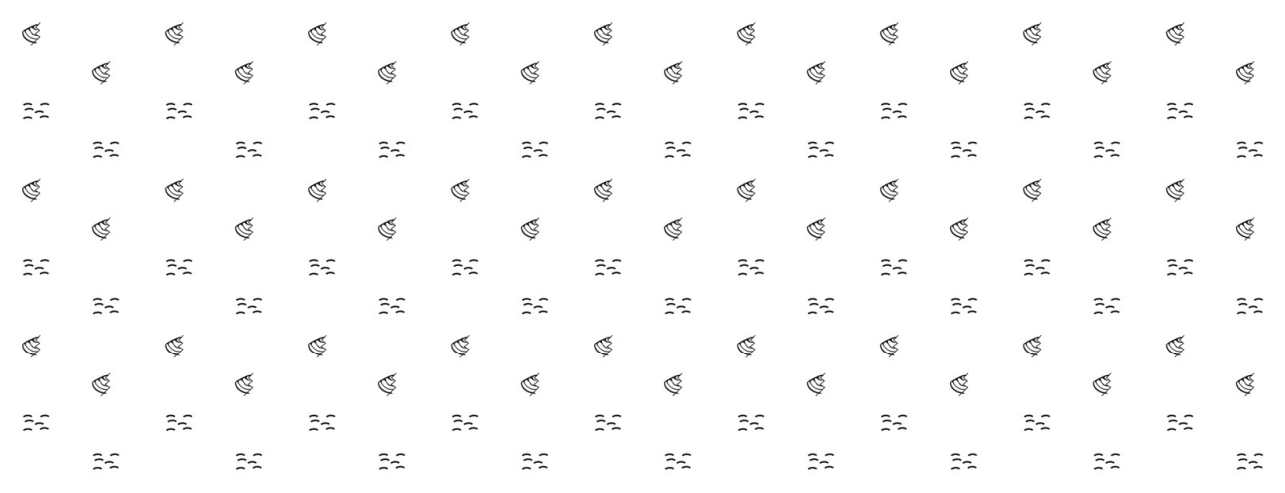

\section{Concha fragmentada/moída- média}

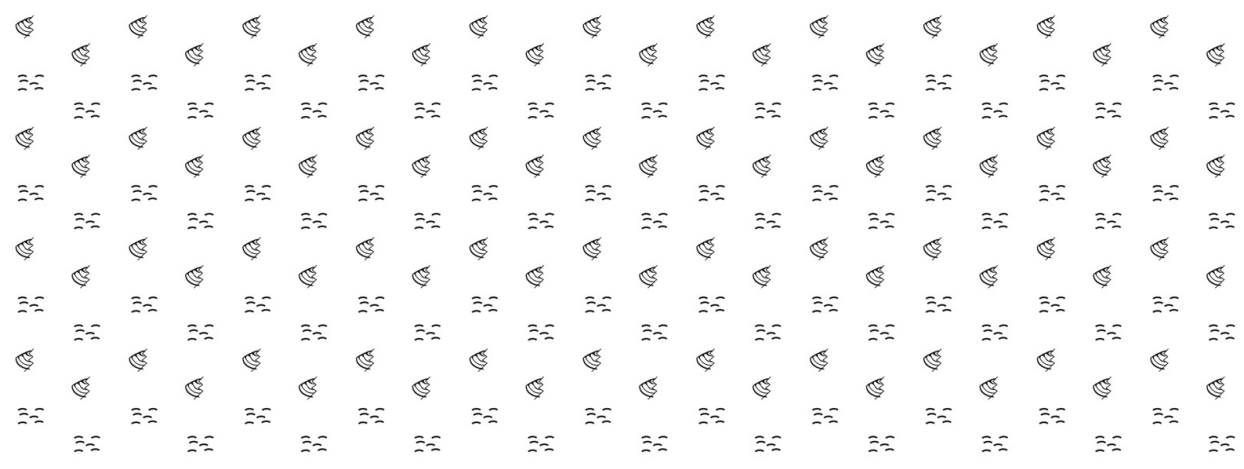

\section{Concha fragmentada/moída- densa}

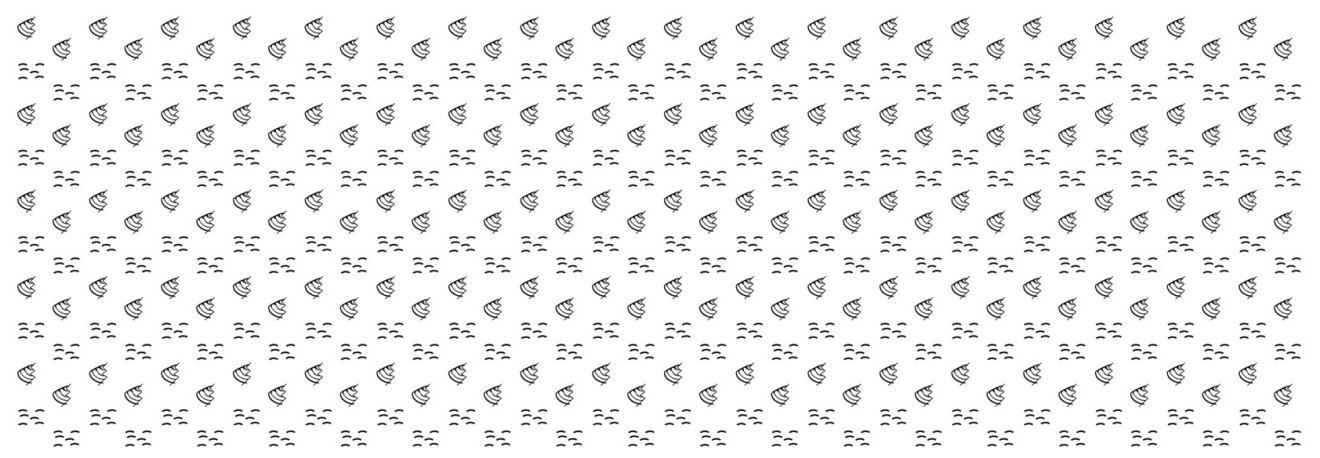




\section{Concha inteira/fragmentada/moída- rarefeita}

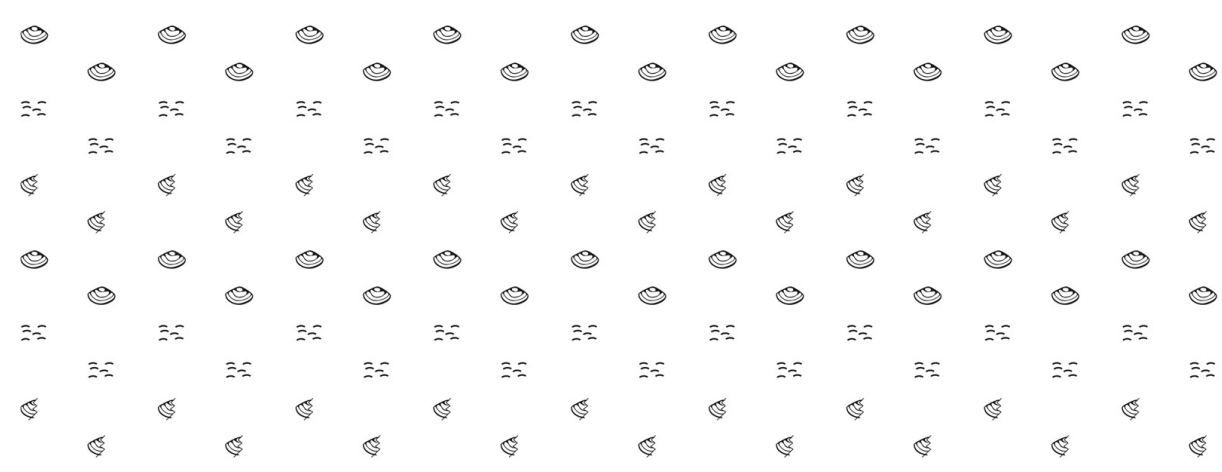

Concha inteira/fragmentada/moída- média

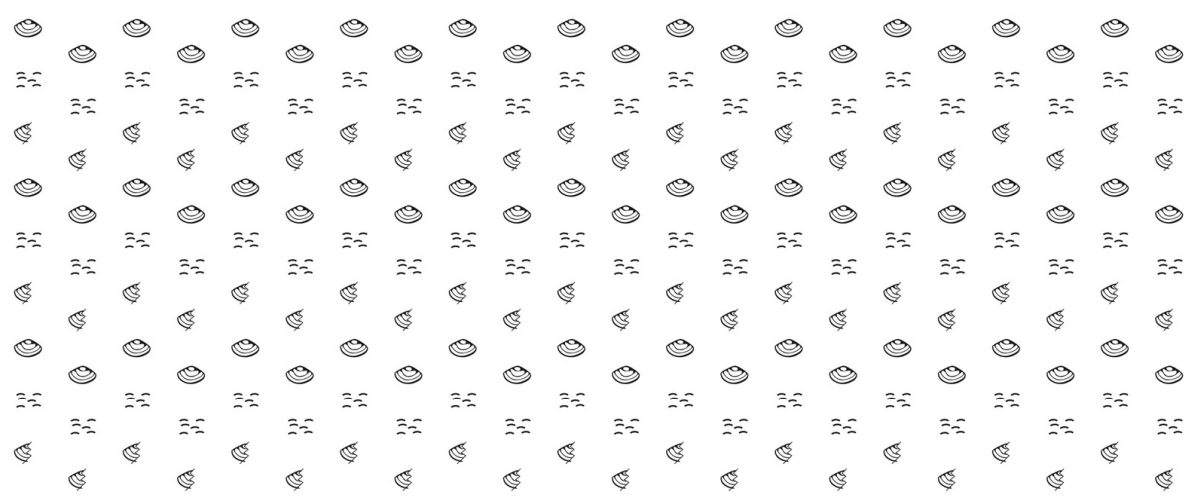

Concha inteira/fragmentada/moída- densa

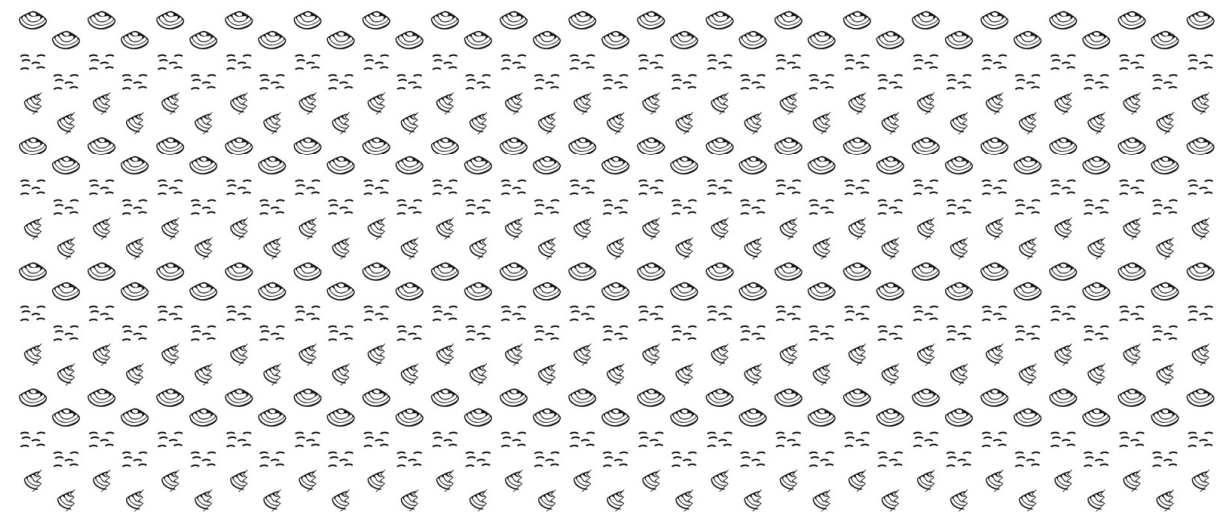

